Prepared in cooperation with the Arkansas Natural Resources Commission and the Arkansas Geological Survey

Potentiometric Surfaces and Water-Level Trends in the Cockfield (Upper Claiborne) Aquifer in Southern Arkansas and the Wilcox (Lower Wilcox) Aquifer of Northeastern and Southern Arkansas, 2012

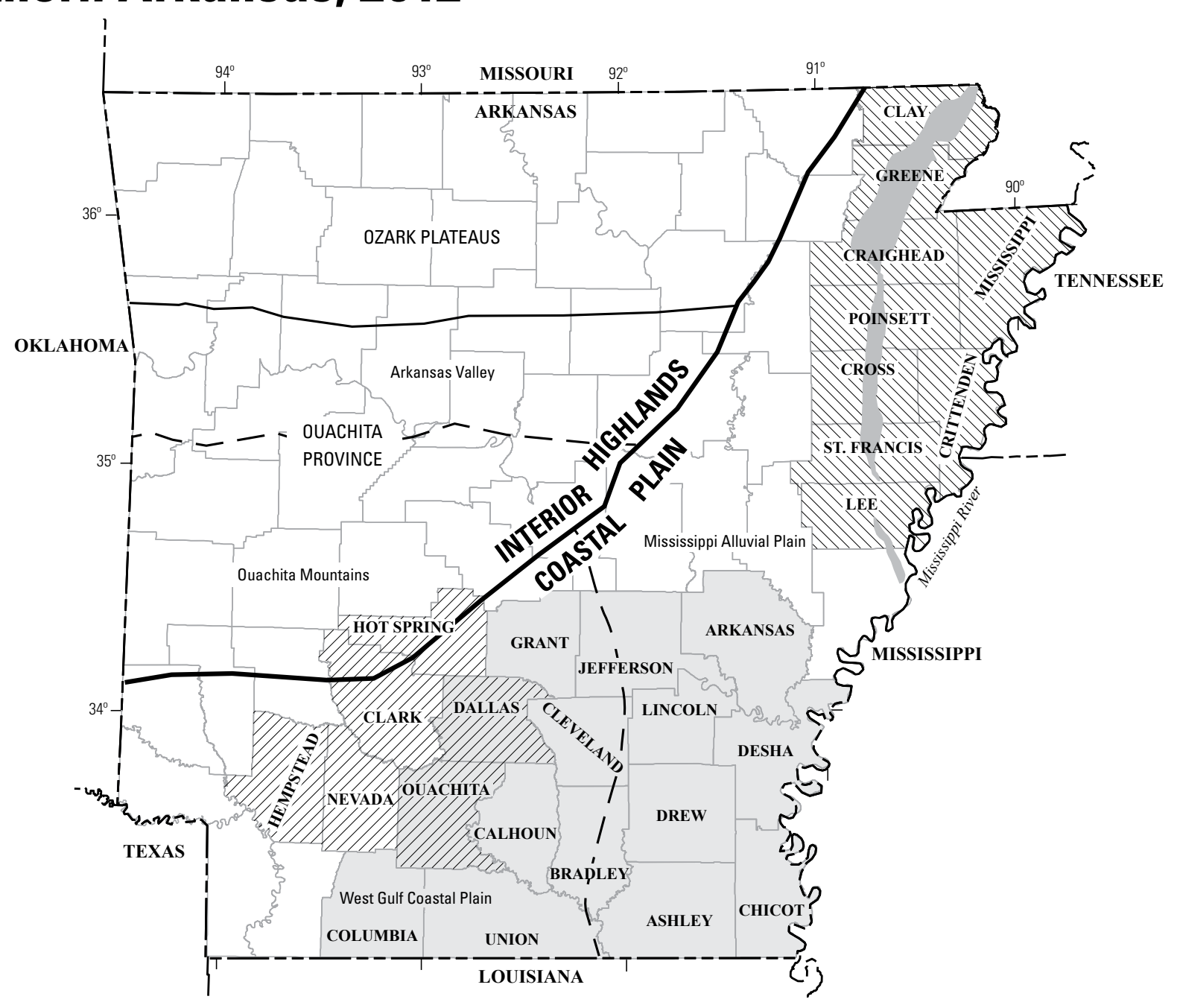

Scientific Investigations Report 2014-5232 



\section{Potentiometric Surfaces and Water- Level Trends in the Cockfield (Upper Claiborne) Aquifer in Southern Arkansas and the Wilcox (Lower Wilcox) Aquifer of Northeastern and Southern Arkansas, 2012}

By Kirk D. Rodgers

Prepared in cooperation with the Arkansas Natural Resources Commission and the Arkansas Geological Survey

Scientific Investigations Report 2014-5232 


\section{U.S. Department of the Interior \\ SALLY JEWELL, Secretary}

\section{U.S. Geological Survey \\ Suzette M. Kimball, Acting Director}

\section{U.S. Geological Survey, Reston, Virginia: 2015}

For more information on the USGS - the Federal source for science about the Earth, its natural and living resources, natural hazards, and the environment, visit http://www.usgs.gov or call 1-888-ASK-USGS.

For an overview of USGS information products, including maps, imagery, and publications, visit http://www.usgs.gov/pubprod

To order this and other USGS information products, visit http://store.usgs.gov

Any use of trade, firm, or product names is for descriptive purposes only and does not imply endorsement by the U.S. Government.

Although this information product, for the most part, is in the public domain, it also may contain copyrighted materials as noted in the text. Permission to reproduce copyrighted items must be secured from the copyright owner.

Suggested citation:

Rodgers, K.D., 2015, Potentiometric surfaces and water-level trends in the Cockfield (upper Claiborne) aquifer in southern Arkansas and the Wilcox (lower Wilcox) aquifer of northeastern and southern Arkansas, 2012: U.S. Geological Survey Scientific Investigations Report 2014-5232, 46 p., http://dx.doi.org/10.3133/sir20145232.

ISSN 2328-0328 (online) 


\section{Contents}

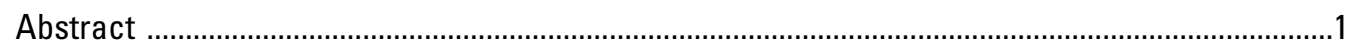

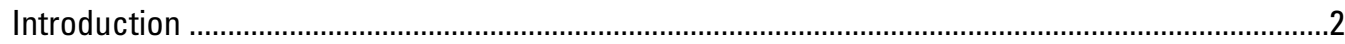

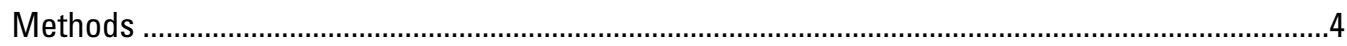

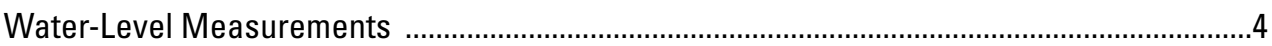

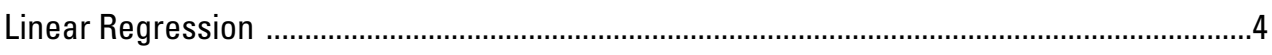

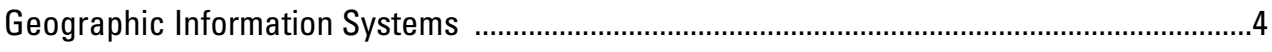

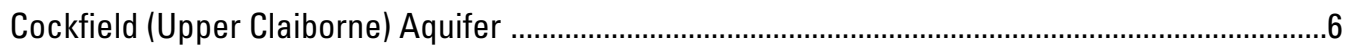

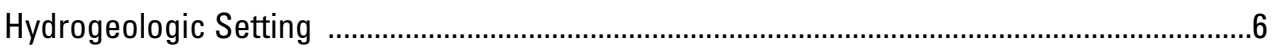

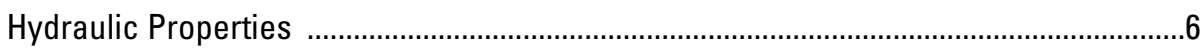

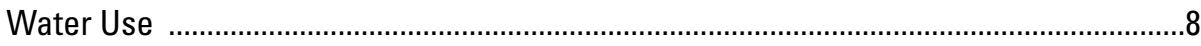

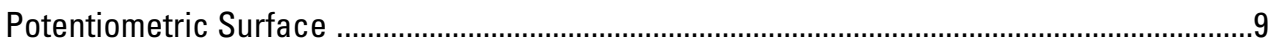

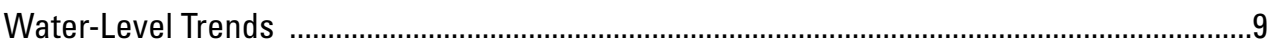

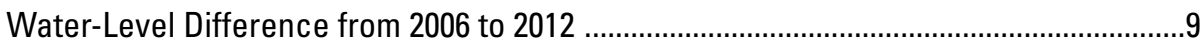

Long-Term Hydrographs .................................................................................12

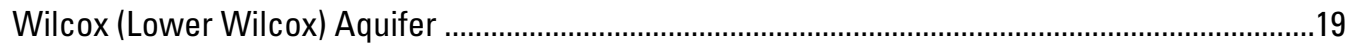

Hydrogeologic Setting ................................................................................................

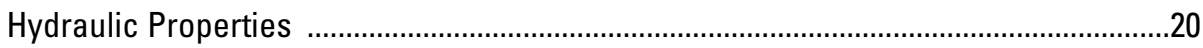

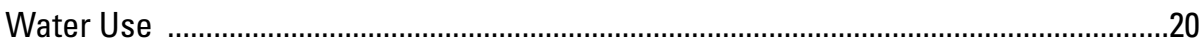

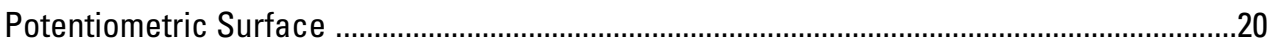

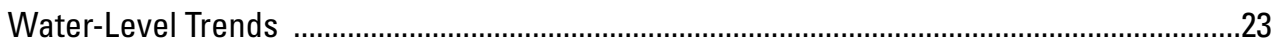

Water-Level Difference from 2006 to 2012 ...............................................................23

Long-Term Hydrographs ...................................................................................23

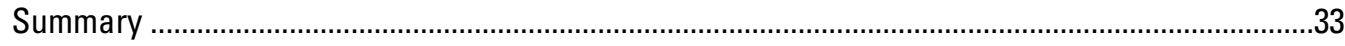

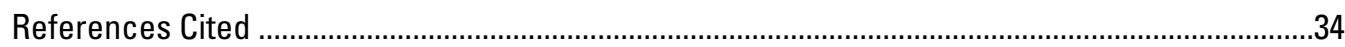

Appendixes

1. Water-level data collected during February 2012 from wells completed in the Cockfield aquifer in southern Arkansas

2. Difference in depth to water from 2006 to 2012 in the Cockfield aquifer in southern Arkansas

3. Water-level data collected during February and March 2012 from wells completed in the Wilcox aquifer in northeastern Arkansas

4. Water-level data collected during February and March 2012 from wells completed in the Wilcox aquifer in southern Arkansas .................................................43

5. Difference in depth to water from 2006 to 2012 in the Wilcox aquifer in northeastern Arkansas

6. Difference in depth to water from 2006 to 2012 in the Wilcox aquifer in southern Arkansas 


\section{Figures}

1. Map showing location of study area of Cockfield aquifer in southern Arkansas and Wilcox aquifer in northeastern and southern Arkansas ............................................

2. Diagram showing well-numbering system ..................................................................

3. Diagram showing generalized section of the hydrogeologic and geologic units within the Mississippi Embayment ................................................................................

4. Bar graph showing water use from the Cockfield aquifer in southern Arkansas, 1975-2010 .8

5. Map showing potentiometric surface of the Cockfield aquifer in southern Arkansas, 2012

6. Map showing water-level difference for the Cockfield aquifer in southern Arkansas, 2006-12

7. Water-level hydrographs for selected wells completed in the Cockfield aquifer in

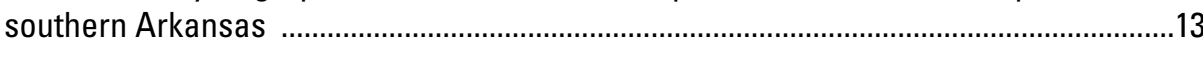

8. Bar graph showing water use from the Wilcox aquifer in Arkansas, 1975-2010 _.........20

9. Map showing potentiometric surface of the Wilcox aquifer in northeastern Arkansas, 2012

10. Map showing potentiometric surface of the Wilcox aquifer in southern Arkansas, 2012

11. Map showng water-level difference for the Wilcox aquifer in northeastern Arkansas, 2006-12

12. Map showng water-level difference for the Wilcox aquifer in southern Arkansas, 2006-12

13. Water-level hydrographs for selected wells completed in the Wilcox aquifer in northeastern Arkansas

14. Water-level hydrographs for selected wells completed in the Wilcox aquifer in southern Arkansas

\section{Tables}

1. Hydrogeologic and geologic units within the Mississippi Embayment of Arkansas

2. Range, mean, and median of annual rise or decline in water level by county for wells with $\mathbf{2 0}$ or more years of record completed in the Cockfield aquifer in Arkansas

3. Range, mean, and median of annual rise or decline in water level by county for wells with 20 or more years of record completed in the Wilcox aquifer in Arkansas 


\section{Conversion Factors}

Inch/Pound to International System of Units

\begin{tabular}{|c|c|c|}
\hline Multiply & By & To obtain \\
\hline \multicolumn{3}{|c|}{ Length } \\
\hline foot $(\mathrm{ft})$ & 0.3048 & meter $(\mathrm{m})$ \\
\hline mile (mi) & 1.609 & kilometer $(\mathrm{km})$ \\
\hline \multicolumn{3}{|c|}{ Flow rate } \\
\hline foot per year (ft/yr) & 0.3048 & meter per year (m/yr) \\
\hline gallon per minute (gal/min) & 0.06309 & liter per second $(\mathrm{L} / \mathrm{s})$ \\
\hline million gallons per day $(\mathrm{Mgal} / \mathrm{d})$ & 0.04381 & cubic meter per second $\left(\mathrm{m}^{3} / \mathrm{s}\right)$ \\
\hline \multicolumn{3}{|c|}{ Specific capacity } \\
\hline $\begin{array}{l}\text { gallon per minute per foot } \\
[(\mathrm{gal} / \mathrm{min}) / \mathrm{ft})]\end{array}$ & 0.2070 & $\begin{array}{l}\text { liter per second per meter } \\
{[(\mathrm{L} / \mathrm{s}) / \mathrm{m}]}\end{array}$ \\
\hline \multicolumn{3}{|c|}{ Transmissivity* } \\
\hline foot squared per day $\left(\mathrm{ft}^{2} / \mathrm{d}\right)$ & 0.09290 & meter squared per day $\left(\mathrm{m}^{2} / \mathrm{d}\right)$ \\
\hline
\end{tabular}

\section{Datum}

Vertical coordinate information is referenced to the National Geodetic Vertical Datum of 1929 (NGVD of 1929)

Horizontal coordinate information is referenced to North American Datum of 1983 (NAD 83).

\section{Supplemental Information}

Altitude, as used in this report, refers to distance above the vertical datum.

*Transmissivity: The standard unit for transmissivity is cubic foot per day per square foot times foot of aquifer thickness $\left[\left(\mathrm{ft}^{3} / \mathrm{d}\right) / \mathrm{ft}^{2}\right] \mathrm{ft}$. In this report, the mathematically reduced form, foot squared per day $\left(\mathrm{ft}^{2} / \mathrm{d}\right)$, is used for convenience. 



\title{
Potentiometric Surfaces and Water-Level Trends in the Cockfield (Upper Claiborne) Aquifer in Southern Arkansas and the Wilcox (Lower Wilcox) Aquifer of Northeastern and Southern Arkansas, 2012
}

\author{
By Kirk D. Rodgers
}

\begin{abstract}
The Cockfield aquifer, located in southern Arkansas, is composed of Eocene-age sand beds found near the base of the Cockfield Formation of Claiborne Group. The Wilcox aquifer, located in northeastern and southern Arkansas, is composed of Paleocene-age sand beds found in the middle to lower part of the Wilcox Group. The Cockfield and Wilcox aquifers are primary sources of groundwater. In 2010, withdrawals from the Cockfield aquifer in Arkansas totaled 19.2 million gallons per day (Mgal/d), and withdrawals from the Wilcox aquifer totaled $36.5 \mathrm{Mgal} / \mathrm{d}$.
\end{abstract}

A study was conducted by the U.S. Geological Survey in cooperation with the Arkansas Natural Resources Commission and the Arkansas Geological Survey to measure water levels associated with the Cockfield aquifer and the Wilcox aquifer in northeastern and southern Arkansas. Water levels were measured at 43 wells completed in the Cockfield aquifer and 47 wells completed in the Wilcox aquifer in February and March 2012. Measurements from 2012 are presented as potentiometric-surface maps and in combination with measurements from 2006 as water-level difference maps. Trends in water-level change over time within the Cockfield and Wilcox aquifers were determined using the water-level difference maps and selected well hydrographs.

The Cockfield aquifer study area in southern Arkansas is bounded on the east by the Mississippi River and on the west by the area that contains outcrops and subcrops of the Cockfield Formation. The northern boundary of the Cockfield aquifer study area is defined by the area that contains observation wells completed in the Cockfield aquifer and the southern boundary is the Louisiana State line.

The Wilcox aquifer study area in northeastern Arkansas is bounded on the east by the Mississippi River and on the north by the Missouri State line. The southern and western boundaries are defined by areas containing observation wells completed in the Wilcox aquifer or by outcrop areas on or near Crowleys Ridge. The Wilcox aquifer study area in southern
Arkansas is defined by observation wells completed in the Wilcox aquifer or by areas that contain outcrops of the Wilcox Group, or both.

The potentiometric-surface map of the Cockfield aquifer shows the regional direction of groundwater flow was generally toward the east-southeast, except in areas of intense groundwater withdrawals such as southwestern Ashley County, where groundwater flows toward the town of Crossett. The highest water-level altitude measured was 350 feet (ft) above National Geodetic Vertical Datum of 1929 (NGVD 29) in central Columbia County. The lowest water-level altitude measured was $40 \mathrm{ft}$ above NGVD 29 in southeastern Lincoln County.

The water-level difference map for the Cockfield aquifer in Arkansas was constructed using 42 water-level measurements made during 2006 and 2012. The difference in water levels for the Cockfield aquifer ranged from $27.4 \mathrm{ft}$ to $-10.4 \mathrm{ft}$. The largest water-level rise was in Calhoun County, and the largest water-level decline was $10.4 \mathrm{ft}$ in Union County. Of the 42 wells, 13 wells had a rise in water level, and the remaining 29 wells had a decline in water level.

Hydrographs for 32 wells in the Cockfield aquifer with historical water-level data were evaluated using linear regression to calculate the annual rise or decline for each well. These data were aggregated by county and statistically evaluated for the range, mean, and median of water-level change in each county. Hydrographs for Bradley, Calhoun, Chicot, Columbia, and Union Counties indicated both rising and declining water levels. The mean annual water-level rise or decline for Calhoun County was 0.00 foot per year ( $\mathrm{ft} / \mathrm{yr}$ ) or unchanged. The mean annual water-level for Ashley, Bradley, Chicot, Cleveland, Columbia, Lincoln, and Union Counties show declines ranging from -0.02 to $-1.10 \mathrm{ft} / \mathrm{yr}$.

Two potentiometric-surface maps, one for the southern area and one for the northeastern area, were constructed to show the altitude of the water surface in the Wilcox aquifer. The direction of groundwater flow in the northeastern area was generally towards the south-southwest except for some areas 
immediately adjacent to the Mississippi River where the flow was more eastward towards the river. The highest water-level altitude was $219 \mathrm{ft}$ in northern Mississippi County, and the lowest water-level altitude was $123 \mathrm{ft}$ near West Memphis in Crittenden County. The direction of groundwater flow in the northern part of the southern area was generally towards the southwest. The direction of groundwater flow in the southern part was in all directions because of two cones of depression and two water-level mounds. The highest water-level altitude measured was $394 \mathrm{ft}$ at the center of a water-level mound in eastern Hot Spring County and a water-level mound in southwestern Hempstead County. The lowest water-level altitude measured was $145 \mathrm{ft}$ at the center of the cone of depression in Clark County.

Water-level difference maps for the Wilcox aquifer in Arkansas were constructed using 47 water-level measurements made during 2006 and 2012. The difference in water levels for the Wilcox aquifer in the northeastern area ranged from $22.0 \mathrm{ft}$ to $-17.9 \mathrm{ft}$. The largest rise in water level occurred in Crittenden County, and the largest decline occurred in Lee County. Twenty-one wells had rising water levels, and 10 wells had declining water levels. The difference in water levels for the Wilcox aquifer in the southern area ranged from $18.1 \mathrm{ft}$ to $-4.2 \mathrm{ft}$. The largest rise and the largest decline in water level occurred in Nevada County. Twelve wells had rising water levels, and 4 wells had declining water levels.

Linear regression analysis of long-term hydrographs was used to determine the mean annual water-level rise and decline in the Wilcox aquifer in the northeastern and southern areas of Arkansas. In the northeastern area, the mean annual water level declined in all seven counties. The mean annual declines ranged from $-0.55 \mathrm{ft} / \mathrm{yr}$ in Craighead County to $-1.46 \mathrm{ft} / \mathrm{yr}$ in St. Francis County. In the southern area, the annual rise and decline calculations for wells with over 20 years of records indicate rising and declining water levels in Clark, Hot Spring, and Nevada Counties. The mean annual water level declined in all counties except Hot Spring County.

\section{Introduction}

The Cockfield aquifer (recognized nationally as the Upper Claiborne aquifer), located in southern Arkansas, is composed of Eocene-age sand beds found near the base of the Cockfield Formation of Claiborne Group. The Middle and Lower Wilcox aquifer (recognized nationally as the lower Wilcox aquifer), located in northeastern and southern Arkansas, is composed of Paleocene-age sand beds found in the lower part of the Wilcox Group. The Cockfield and Wilcox aquifers are sources of groundwater for local use. In 2010, withdrawals from the Cockfield aquifer in Arkansas totaled 19.2 million gallons per day (Mgal/d), and withdrawals from the Wilcox aquifer totaled $36.5 \mathrm{Mgal} / \mathrm{d}$. In 2010, the Cockfield aquifer in Arkansas ranked fifth in combined usage for the State, and the Wilcox aquifer ranked third.

A study was conducted by the U.S. Geological Survey (USGS) in cooperation with the Arkansas Natural Resources Commission and the Arkansas Geological Survey to determine water levels associated with the Cockfield aquifer in southern Arkansas and the Wilcox aquifer in northeastern and southern Arkansas. In February and March 2012, water levels were measured at 43 wells completed in Cockfield aquifer and 47 wells completed in the Wilcox aquifer. These water-level measurements are presented as potentiometric-surface maps, in combination with measurements from 2006 as water-level difference maps, and in long-term hydrographs.

The study areas of the Cockfield and Wilcox aquifers are part of the Mississippi Embayment that includes much of the West Gulf Coastal Plain and the Mississippi Alluvial Plain in Arkansas (fig. 1). The Mississippi Embayment is a north-northeast trending syncline, plunging south-southwest, and is filled with Cretaceous and younger-age sediments. The study area of the Cockfield aquifer in southern Arkansas is bounded on the east by the Mississippi River and on the west by the area that contains outcrops and subcrops of the Cockfield Formation (Hosman, 1982). The northern boundary of the Cockfield aquifer study area is defined by the locations of observation wells completed in the Cockfield aquifer, and the southern boundary is the Louisiana State line (fig. 1). The Wilcox aquifer study area in northeastern Arkansas is bounded on the east by the Mississippi River and on the north by the Missouri State line. The southern and western boundaries are defined by areas containing observation wells completed in the Wilcox aquifer or by outcrop areas in or near Crowleys Ridge. Crowleys Ridge is an erosional remnant of Cretaceous- and Tertiary-age rocks that ranges from 0.5 to 12 miles (mi) wide, rises 250 to 550 feet (ft) above the surrounding Mississippi Alluvial Plain, and extends about $150 \mathrm{mi}$ from southeastern Missouri to east-central Arkansas. The Wilcox aquifer study area in southern Arkansas is defined by observation wells completed in the Wilcox aquifer or by areas that contain outcrops of the Wilcox Group, or both.

This is the sixth in a series of triennial reports discussing the potentiometric surfaces of the Cockfield and Wilcox aquifers in Arkansas. Earlier reports, with water-level measurements made in 1991, 1996-97, 2000, 2003, 2006, and 2009 are reported in Westerfield (1994), Joseph (1998), Schrader and Joseph (2000), Yeatts (2004), Schrader (2007), and Pugh (2010). 


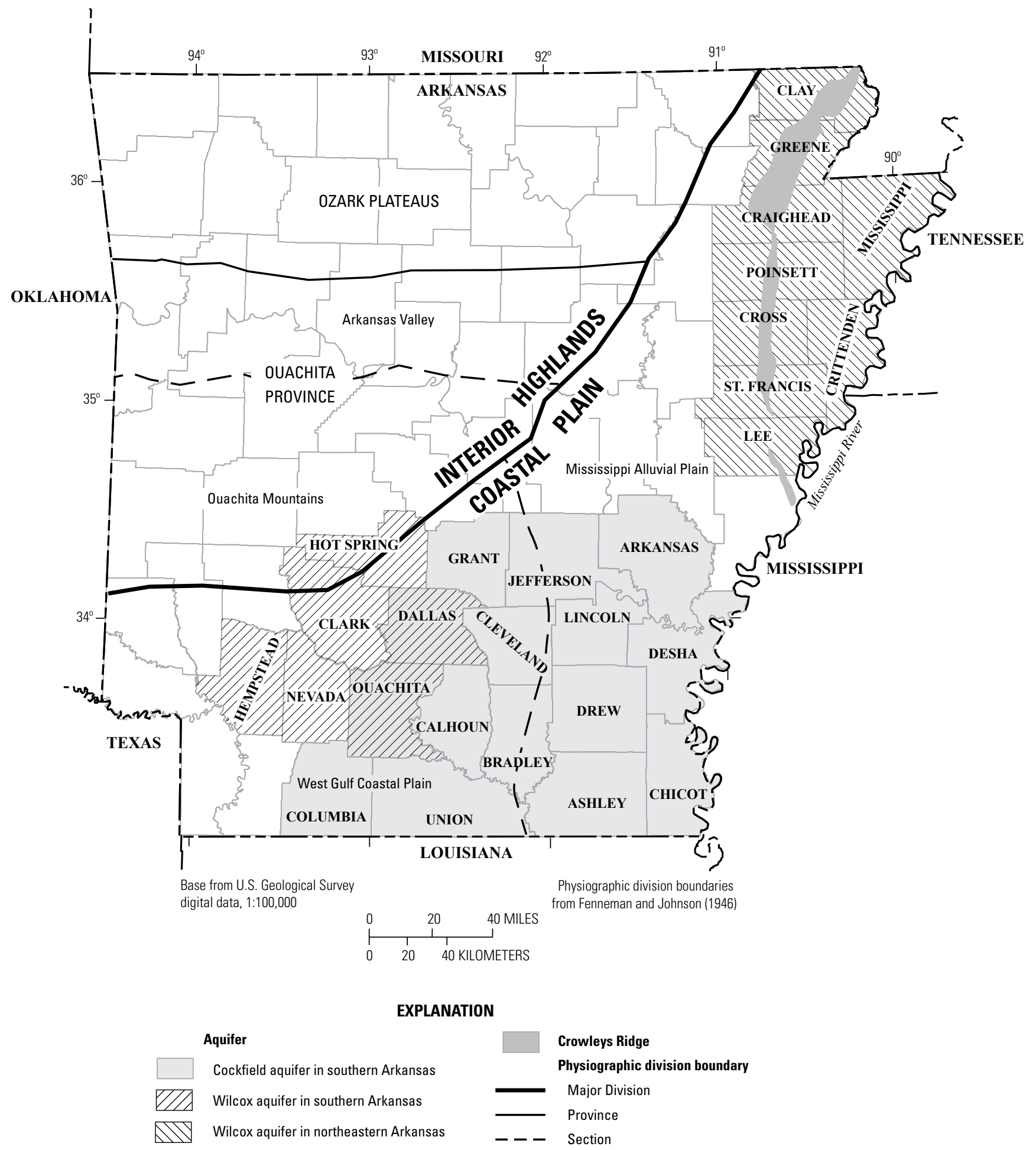

Figure 1. Location of study area of Cockfield aquifer in southern Arkansas and Wilcox aquifer in northeastern and southern Arkansas. 


\section{Methods}

The well-numbering system used in this report is based on location of wells according to the Public Land Survey System used in Arkansas (U.S. Geological Survey, 2014). The component parts of a well number are the township number, the range number, the section number, three letters which indicate, respectively, the quarter section, the quarterquarter section, and the quarter-quarter-quarter section in which the well is located, and a sequence number. The letters are assigned counterclockwise, beginning with " $\mathrm{A}$ " in the northeast quarter, quarter-quarter, or quarter-quarter-quarter section in which the well is located. For example, well 01S03W04BBD16 (fig. 2) is located in Township 1 South, Range 3 West, and in the southeast quarter of the northwest quarter of the northwest quarter of section 4 . This well is the 16th well in this quarter-quarter-quarter section of section 4 from which data were collected (Pugh, 2010).

The horizontal coordinate information (latitude and longitude) of a well was determined using a global positioning system, and land-surface altitude information was determined using a USGS 7.5-minute, 1:24,000 quadrangle topographic map. The horizontal coordinate information is based on the North American Datum of 1983 and is accurate to about onetenth of a second (approximately 10-20 ft). The location of the well was then plotted on the corresponding topographic map and the land-surface altitude at that point was determined by interpolation of the topographic contours. This altitude is accurate to about one-half the contour interval of the topographic map, which is based on the National Geodetic Vertical Datum of 1929 (NGVD 29).

\section{Water-Level Measurements}

Water levels were measured by USGS personnel at public water-supply, industrial, commercial, domestic, and observation wells completed in the Cockfield or Wilcox aquifers. Measurements were made using steel or electric field tapes graduated to hundredths of a foot. The steel and electric tapes used by USGS personnel were calibrated during January 2010, prior to collecting water-level measurements. Calibration of steel and electric tapes was performed by comparing the field steel or electric tape to a standardized steel tape used only for calibration of field tapes. The waterlevel data are stored in the USGS National Water Information System (NWIS) (U.S. Geological Survey, 2002).

Potentiometric-surface maps for the Cockfield and Wilcox aquifers in Arkansas were constructed by plotting well positions with their respective water-level altitude using ArcGIS (Esri, 2011). The altitude of the water level in each well was determined by subtracting the measured depth to water from the land-surface altitude. The direction of groundwater flow is perpendicular to the contours in the direction of decreasing water level.
Water-level difference maps for the Cockfield and Wilcox aquifers in Arkansas were constructed using the differences between depth-to-water measurements made during 2006 and 2012. The difference in water level was calculated by subtracting the 2012 depth-to-water value from the 2006 depth-to-water value for each individual well. Positive difference values indicate a rise in water level, and negative difference values indicate a decline in water level.

\section{Linear Regression}

A linear regression analysis was used to determine the annual rise or decline of water level in selected wells using the well hydrograph. Water-level measurements made yearly during March, April, and May of the minimum 20-year period of record were used in the linear regression analysis. The equation of the regression line or line of best fit is $\mathrm{Y}=\mathrm{MX}$ $+\mathrm{B}$. The slope, $\mathrm{M}$ from the equation, represents the daily rise or decline in water level, B is the water level measured in feet at the $\mathrm{y}$-intercept and $\mathrm{X}$ is the year in which the measurement was made. Five assumptions are associated with linear regression: (1) $\mathrm{Y}$ is linearly related to $\mathrm{X}$, (2) data used to fit the linear regression are representative of data of interest, (3) variance of the residuals is constant and does not depend on X or on anything else, (4) the residuals are independent, and (5) the residuals are normally distributed. The assumption of a normal distribution is involved only when testing hypotheses, requiring the residuals from the regression equation to be normally distributed (Helsel and Hirsch, 1992). Water-level measurements collected during February and March of 2006 and 2012 were used for linear regression analysis.

\section{Geographic Information Systems}

Longitudes, latitudes, and measured water-level altitudes of the Cockfield and Wilcox aquifer wells were obtained from NWIS and geocoded using ArcGIS (Esri, 2011), which is a computer-based application used to visually represent spatially based data using geographic coordinates. These data points were then interpolated using the kriging method of interpolation to construct potentiometric-surface maps of the Cockfield and Wilcox aquifers. This process produces a raster image in which each color represents a range of water-level values. The raster images were then converted to contour lines using the ArcGIS Contour tool. Upon conversion, the contour polylines were corrected and refined using the Polynomial Approximation with Exponential Kernel (PAEK) method of smoothing (Bodansky and others, 2002). The PAEK method uses a maximum allowable offset to smooth lines. PAEK is a smoothing algorithm that sets a tolerance by which lines are smoothed. A higher tolerance preserves less detail from the original interpolated contour line, and a lower tolerance preserves more detail. This method allows for the preservation of end points. 


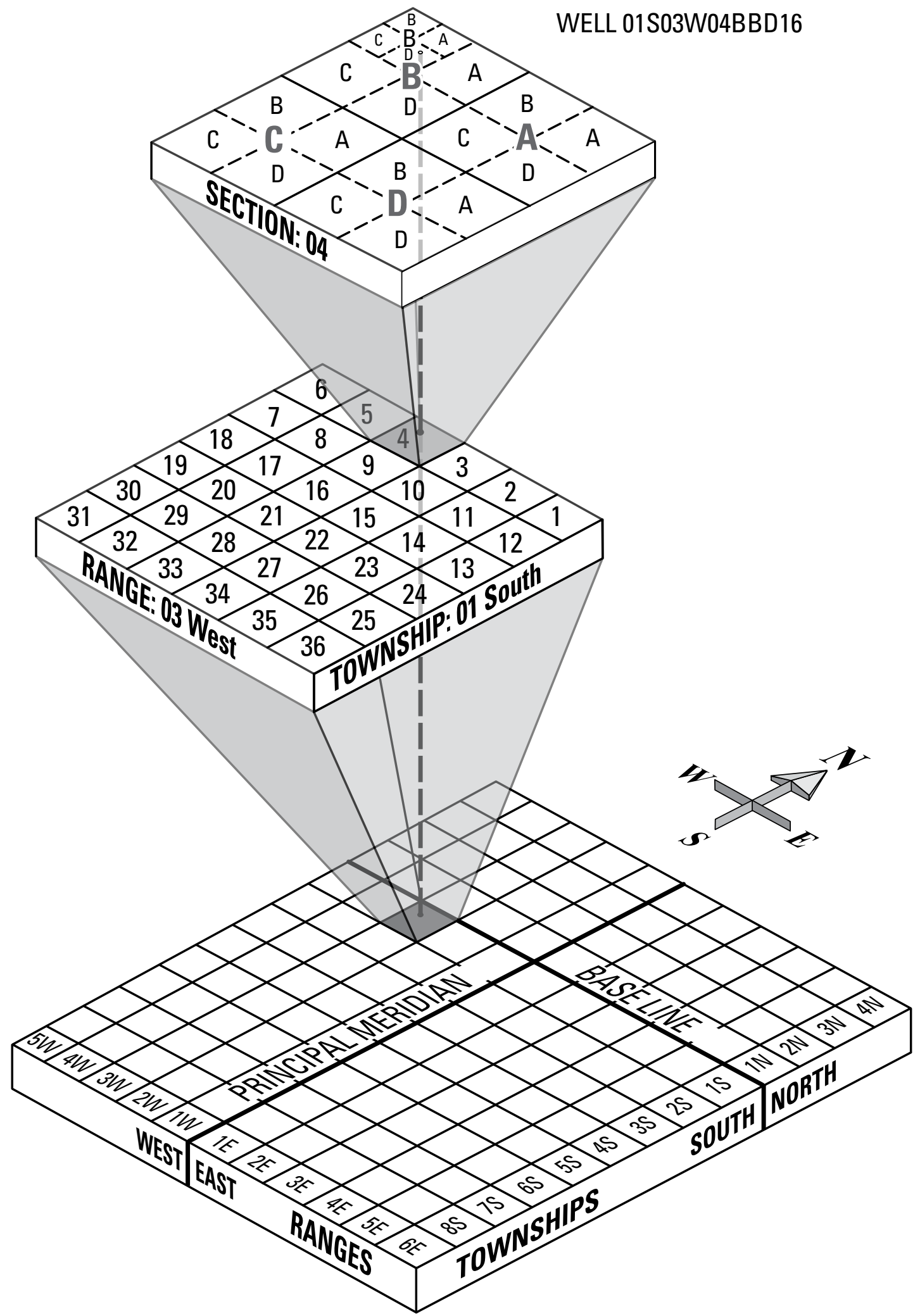

Figure 2. Well-numbering system. 


\section{Cockfield (Upper Claiborne) Aquifer}

\section{Hydrogeologic Setting}

The Cockfield aquifer generally consists of discontinuous fine- to medium-grained sand units interbedded with silt, clay, and lignite of nonmarine origin. Most of the sand beds of the Cockfield aquifer are located near the base of the Cockfield Formation of Claiborne Group (hereafter referred to as Cockfield Formation) (table 1). The Cockfield Formation ranges from 100 to $400 \mathrm{ft}$ thick in the outcrop areas and thickens downdip to about $625 \mathrm{ft}$ in northeastern Chicot County (Onellion and Criner, 1955). The Cockfield Formation dips to the south and east towards the synclinal axis of the Mississippi Embayment (fig. 3). Thicknesses of the sand beds of the Cockfield aquifer generally range from 20 to 150 $\mathrm{ft}$. Throughout the study area, the Cockfield Formation is underlain by calcareous and sandy marl, carbonaceous clay, and limestone of the Cook Mountain Formation of Claiborne Group (table 1). In much of the study area, the Cockfield Formation is overlain by silty clays of the Jackson Group.

The potentiometric surface can be near or above land surface in the confined part of the Cockfield aquifer. Sand beds at the base of the overlying Jackson Group in parts of southern Arkansas may be in hydraulic connection with the Cockfield aquifer (Ackerman, 1987). The Cockfield Formation and aquifer outcrop in Bradley, Calhoun, Cleveland, Columbia, Dallas, Grant, and Union Counties and dips to the southeast. In the subcrop area, Quaternary-age terrace deposits and alluvium overlie the Cockfield Formation. The thickness of terrace deposits may reach $40 \mathrm{ft}$, and as much as $60 \mathrm{ft}$ of alluvium overlies the formation in some of the larger river valleys A generalized section of the hydrogeologic and geologic units within the Mississippi Embayment are shown in figure 3 .

Most of the Cockfield aquifer recharge occurs by infiltration of rainfall on the upland outcrop areas and by inflow from the overlying alluvium or rivers that have eroded through the overburden connecting them hydrologically with the aquifer. Discharge from the aquifer is to hydrologically connected rivers in the outcrop areas, vertically to adjacent hydrogeologic units where the aquifer is confined, and to wells completed in the aquifer (Ackerman, 1987). In the outcrop areas, well depths in the aquifer are less than $200 \mathrm{ft}$ and well yields are small, usually less than 30 gallons per minute (gal/ $\mathrm{min}$ ), but in areas downdip from the outcrop areas, wells screening the full thickness of the aquifer may yield from 100 to $500 \mathrm{gal} / \mathrm{min}$ (Westerfield, 1994).

\section{Hydraulic Properties}

Values for specific capacity and transmissivity vary within the Cockfield aquifer. Specific capacity values range from 0.15 gallon per minute per foot $[(\mathrm{gal} / \mathrm{min}) \mathrm{ft})]$ to $23.7(\mathrm{gal} / \mathrm{min}) / \mathrm{ft}$ with a median of $0.76(\mathrm{gal} / \mathrm{min}) / \mathrm{ft}$. Transmissivity values range from 325 feet squared per day $\left(\mathrm{ft}^{2} / \mathrm{d}\right)$ to $6,280 \mathrm{ft}^{2} / \mathrm{d}$ with a median of $3,350 \mathrm{ft}^{2} / \mathrm{d}$ and a mean of $3,300 \mathrm{ft}^{2} / \mathrm{d}$. Hydraulic conductivity values were not provided for any of the well tests completed in the Cockfield aquifer. An estimated hydraulic conductivity value for the Cockfield aquifer was determined by dividing the mean transmissivity value $\left(3,300 \mathrm{ft}^{2} / \mathrm{d}\right)$ by the maximum aquifer thickness ( $\left.400 \mathrm{ft}\right)$, resulting in a value of $8.33 \mathrm{ft} / \mathrm{d}$ (Pugh, 2008). 
Table 1. Hydrogeologic and geologic units within the Mississippi Embayment of Arkansas (modified from Hosman and Weiss, 1991; Hart and others, 2008).

[Dashed lines indicate the approximate location where hydrogeologic units begin and end]

\begin{tabular}{|c|c|c|c|c|c|c|c|}
\hline & \multirow{2}{*}{ 兽 } & \multirow{2}{*}{ ڤ્ळ } & \multirow{2}{*}{ 옴 } & \multicolumn{2}{|c|}{ Geologic unit } & \multirow{2}{*}{\multicolumn{2}{|c|}{$\begin{array}{c}\text { Hydrogeologic } \\
\text { unit }\end{array}$}} \\
\hline 营 & & & & $\begin{array}{l}\text { Southern } \\
\text { Arkansas }\end{array}$ & $\begin{array}{l}\text { Northeastern } \\
\text { Arkansas }\end{array}$ & & \\
\hline \multirow{12}{*}{ 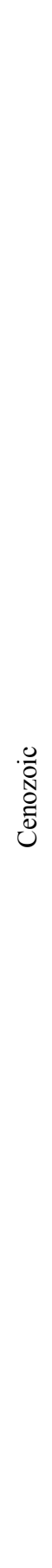 } & 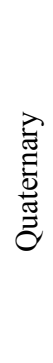 & 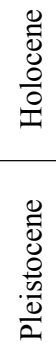 & \multirow[b]{2}{*}{$\begin{array}{l}0 \\
0 \\
0 \\
0 \\
0 \\
0 \\
5\end{array}$} & \multicolumn{2}{|c|}{ Alluvium and terrace deposits } & \multicolumn{2}{|c|}{$\begin{array}{c}\text { Mississippi River Valley } \\
\text { alluvial aquifer }\end{array}$} \\
\hline & \multirow{11}{*}{ 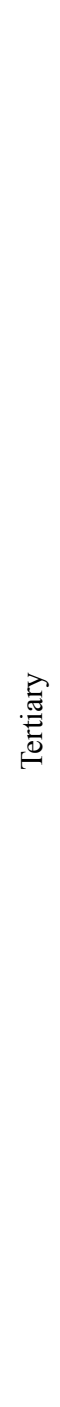 } & $\begin{array}{l}0 \\
\overline{0} \\
8 \\
.00 \\
00\end{array}$ & & \multicolumn{2}{|c|}{ Not present in study areas } & \multirow{2}{*}{\multicolumn{2}{|c|}{$\begin{array}{l}\text { Vicksburg-Jackson } \\
\text { confining unit }\end{array}$}} \\
\hline & & \multirow{6}{*}{$\begin{array}{l}\mathscr{0} \\
\stackrel{0}{0} \\
\text { I }\end{array}$} & 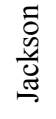 & \multicolumn{2}{|c|}{ Jackson Formation } & & \\
\hline & & & \multirow{5}{*}{ 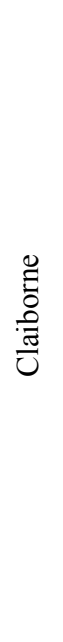 } & \multicolumn{2}{|c|}{ Cockfield Formation } & \multicolumn{2}{|c|}{$\begin{array}{l}\text { Upper Claiborne aquifer } \\
\text { (Cockfield aquifer) }\end{array}$} \\
\hline & & & & \multicolumn{2}{|c|}{ Cook Mountain Formation } & \multicolumn{2}{|c|}{$\begin{array}{c}\text { Middle Claiborne } \\
\text { confining unit }\end{array}$} \\
\hline & & & & Sparta Sand & \multirow{3}{*}{ Memphis Sand } & & \\
\hline & & & & $\begin{array}{l}\text { Cane River } \\
\text { Formation }\end{array}$ & & $\begin{array}{l}\text { Lower } \\
\text { Claiborne } \\
\text { confining } \\
\text { unit }\end{array}$ & $\begin{array}{l}\text { Middle } \\
\text { Claiborne } \\
\text { aquifer }\end{array}$ \\
\hline & & & & Carrizo Sand & & $\begin{array}{l}\text { Lower } \\
\text { Claiborne } \\
\text { aquifer }\end{array}$ & \\
\hline & & \multirow{4}{*}{ 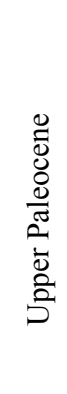 } & \multirow{3}{*}{$\frac{\stackrel{x}{0}}{3}$} & \multirow{3}{*}{ Undifferentiated } & $\begin{array}{r}\text { Flour Island } \\
\text { Formation }\end{array}$ & \multicolumn{2}{|c|}{ Middle Wilcox aquifer } \\
\hline & & & & & Fort Pillow Sand & \multirow{2}{*}{\multicolumn{2}{|c|}{ Lower Wilcox aquifer }} \\
\hline & & & & & $\begin{array}{l}\text { Old Breastworks } \\
\text { Formation }\end{array}$ & & \\
\hline & & & & \multicolumn{2}{|c|}{ Midway Group } & \multicolumn{2}{|c|}{ Midway confining unit } \\
\hline
\end{tabular}




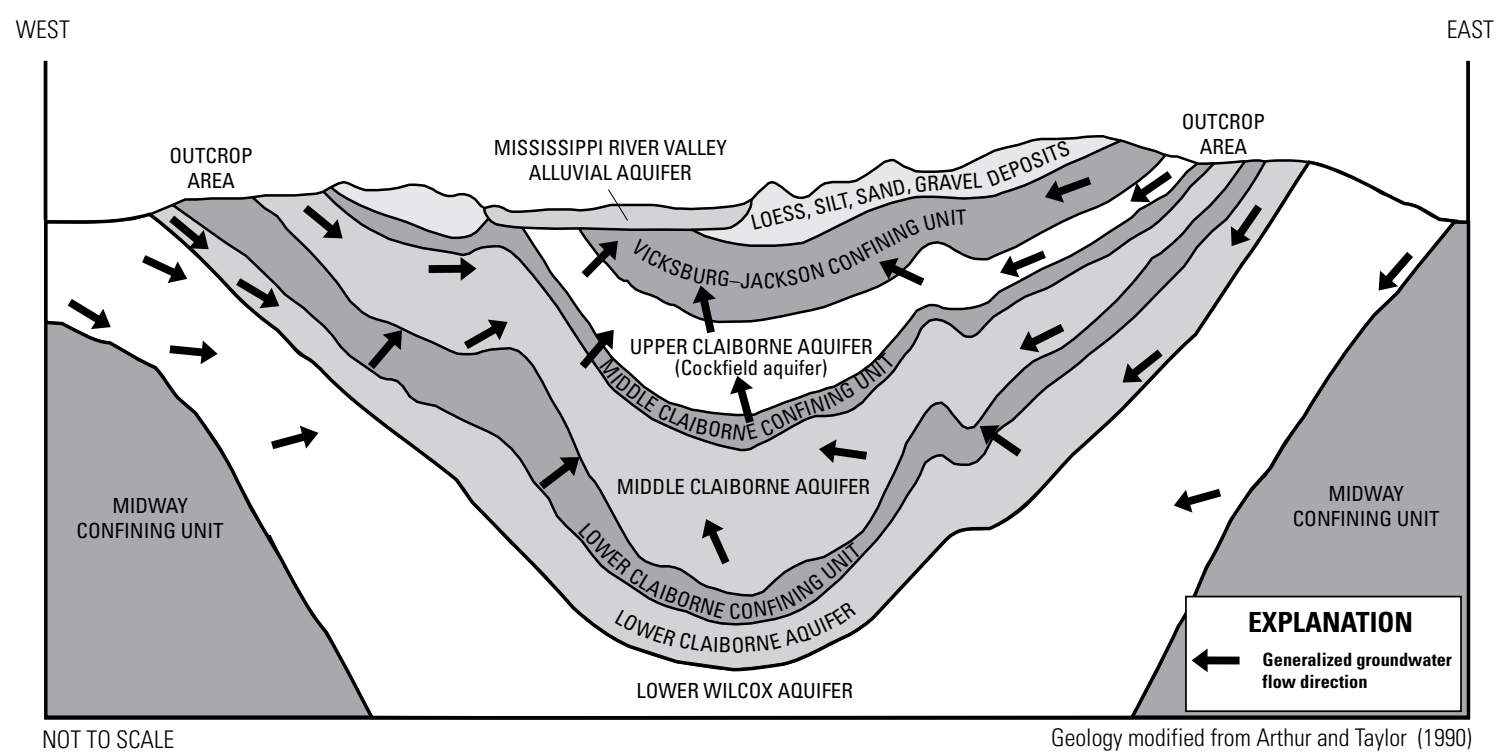

Figure 3. Generalized section of the hydrogeologic and geologic units within the Mississippi Embayment.

\section{Water Use}

Withdrawals from the Cockfield aquifer during 2010 totaled about $19.2 \mathrm{Mgal} / \mathrm{d}$ (Terrance W. Holland, U.S. Geological Survey written commun., 2013) (fig. 4). These withdrawals were primarily for industrial and public supply use, but withdrawals for agricultural, commercial, and domestic use are important locally. Withdrawals from the Cockfield aquifer rose from 1975 to 2010, with the exception of 1985 . Withdrawals were $5.2 \mathrm{Mgal} / \mathrm{d}$ in $1975,7.2 \mathrm{Mgal} / \mathrm{d}$ in $1980,5.0 \mathrm{Mgal} / \mathrm{d}$ in $1985,8.1 \mathrm{Mgal} / \mathrm{d}$ in $1990,9.8 \mathrm{Mgal} / \mathrm{d}$ in 1995, 9.9 Mgal/d in 2000, and 16.1 Mgal/d in 2005 (Halberg and Johnson, 1977; Holland and Ludwig, 1981; Holland, $1987,1993,1999,2004,2007)$. The increase in withdrawals from the Cockfield aquifer between 2000 (9.9 Mgal/d) and 2005 (16.1 Mgal/d) are associated with increased use of water by public water-supply systems in eastern Arkansas (Holland, 2004, 2007; Pugh, 2010), and the increase in withdrawals from the aquifer between 2005 (16.1 Mgal/d) and 2010 (19.2 Mgal/d) are associated with increased industrial use of water in eastern Arkansas (Terrance W. Holland, U.S. Geological Survey written commun., 2013). Most wells completed in the study area provide small volumes of water for domestic and livestock use, but in some locations, the aquifer yields volumes large enough to supply industrial and public-supply systems.

In 2010, the State of Mississippi withdrew $22.8 \mathrm{Mgal} / \mathrm{d}$ of water from the Cockfield aquifer. Across the State line from Chicot County, Ark., the city of Greenville, Miss., withdrew 10.4 Mgal/d of water for public supply from the Cockfield aquifer in 2010 (D.E. Burt, U.S. Geological Survey, written commun., 2013). Withdrawals from the aquifer in Mississippi rose 170 percent between 1999 and 2005 (D.E. Burt,
U.S. Geological Survey, written commun., 2009) and decreased by 50 percent between 2005 and 2010 (D.E. Burt, U.S.Geological Survey, written commun., 2013). The large amount of water withdrawn in Mississippi from the aquifer probably contributed to lower water levels in southeastern Arkansas (Ackerman, 1987; Joseph, 1998; Schrader and Joseph, 2000; Yeatts, 2004; Pugh, 2010).

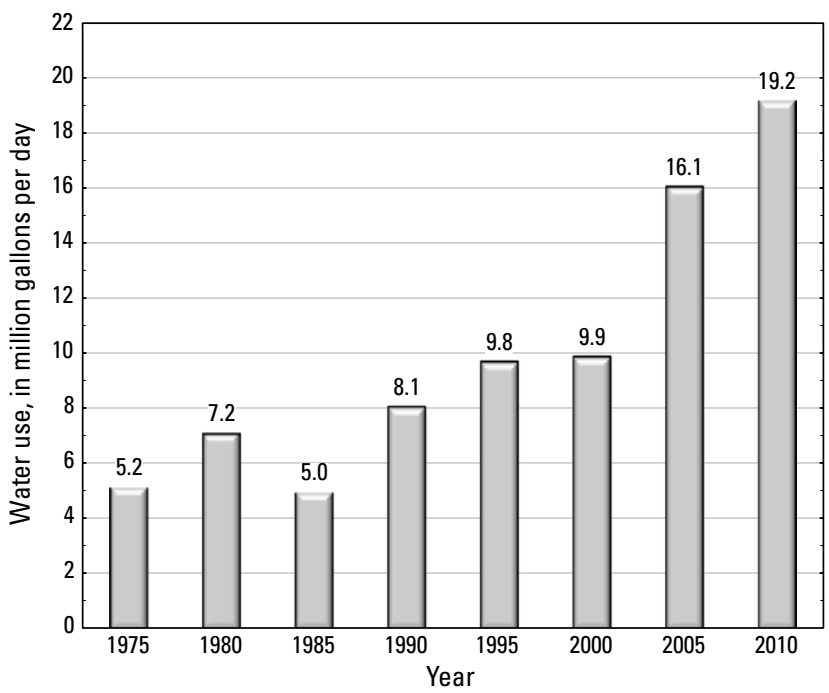

Data compiled from Halberg and Johnson (1977), Holland and Ludwig (1981), and Holland (1987, 1993, 1999, 2004, 2007, Terrance W. Holland, U.S. Geological Survey, written commun., 2010)

Figure 4. Water use from the Cockfield aquifer in southern Arkansas, 1975-2010. 


\section{Potentiometric Surface}

The potentiometric-surface map shows the altitude of the water surface in tightly cased wells screened in the Cockfield aquifer in the study area (fig. 5). Water-level data used to construct the map are shown in appendix 1.

The potentiometric surface of the Cockfield aquifer in 2012 shows the regional direction of groundwater flow generally is towards the east-southeast, except in areas of intense groundwater withdrawals, such as southwestern Ashley County where groundwater flows toward the town of Crossett. In southern Columbia County, a trough in the potentiometic surface exists, which locally alters the flow of groundwater. This trough may indicate the formation of a cone of depression. In northeastern Drew County and northern Chicot County, groundwater flow is towards the northeast, and in southeastern Lincoln County, groundwater flow is towards the east. The highest water-level altitude measured was $350 \mathrm{ft}$ above NGVD 29 in central Columbia County. This elevated water-level altitude is the result of the well being located on a higher land-surface altitude in the outcrop area. The lowest water-level altitude measured was $40 \mathrm{ft}$ above NGVD 29 in southeastern Lincoln County.

\section{Water-Level Trends}

\section{Water-Level Difference from 2006 to 2012}

A water-level difference map for the Cockfield aquifer in the study area was constructed to spatially evaluate short-term (6 years) changes in water levels (fig. 6). The map was constructed using the difference between water-level measurements made in 2006 and 2012 in 42 wells (app. 2). Positive values, represented with blue, upward pointing triangles, indicate a rise in water levels between 2006 and 2012; negative values, represented with red, downward pointing triangles, indicate a decline in water levels between 2006 and 2012. The triangles are scaled in size to the relative value of rise or decline. The 2006 to 2012 water-level difference map indicates short-term changes and may not represent long-term trends.

The 2006 to 2012 difference in water levels for the Cockfield aquifer ranged from 27.4 to $-10.4 \mathrm{ft}$ (fig. 6). The largest water-level rise was in Calhoun County, and the largest water-level decline was in Union County (app. 2). Of the 42 wells, 13 wells had a rise in water levels, and the remaining 29 wells had a decline in water levels from 2006 to 2012. Rises in water levels occurred in Ashley, Bradley, Calhoun, Chicot, Cleveland, Columbia, Drew, and Union Counties and ranged from $27.4 \mathrm{ft}$ in Calhoun County to $0.2 \mathrm{ft}$ in Bradley County. Declines in water levels ranged from $-0.3 \mathrm{ft}$ in Calhoun and Columbia Counties to $-10.4 \mathrm{ft}$ in Union County, and most were less than $-5.0 \mathrm{ft}$.

East of the Saline River, water levels declined in 12 of the 16 wells between 2006 and 2012. In Ashley County, 6 of the 7 wells had declines in water levels. Eleven of the 15 wells located between the Saline and Ouachita Rivers had declines in water levels, and 6 of the 11 wells west of the Ouachita River had declines in water levels for the period between 2006 and 2012. 


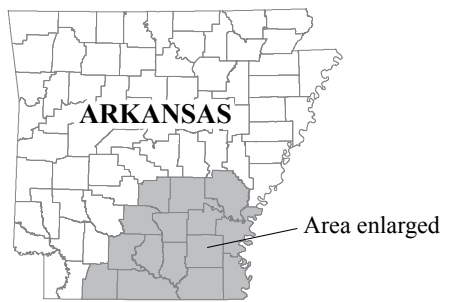

EXPLANATION

Outcrop of the Cockfield Formation (modified from Hosman, 1988)

- 200-- Potentiometric contour-Shows altitude at which water level would have stood in tightly cased wells. Dashed where approximately located. Contour interval 20 feet. Datum is

$\rightarrow \quad$ General direction of groundwater flow

$\boldsymbol{A}^{\bullet} \quad$ Well completed in Cockfield aquifer-Number is water-level altitude. Letter, where present, corresponds to hydrograph in figure 7
con
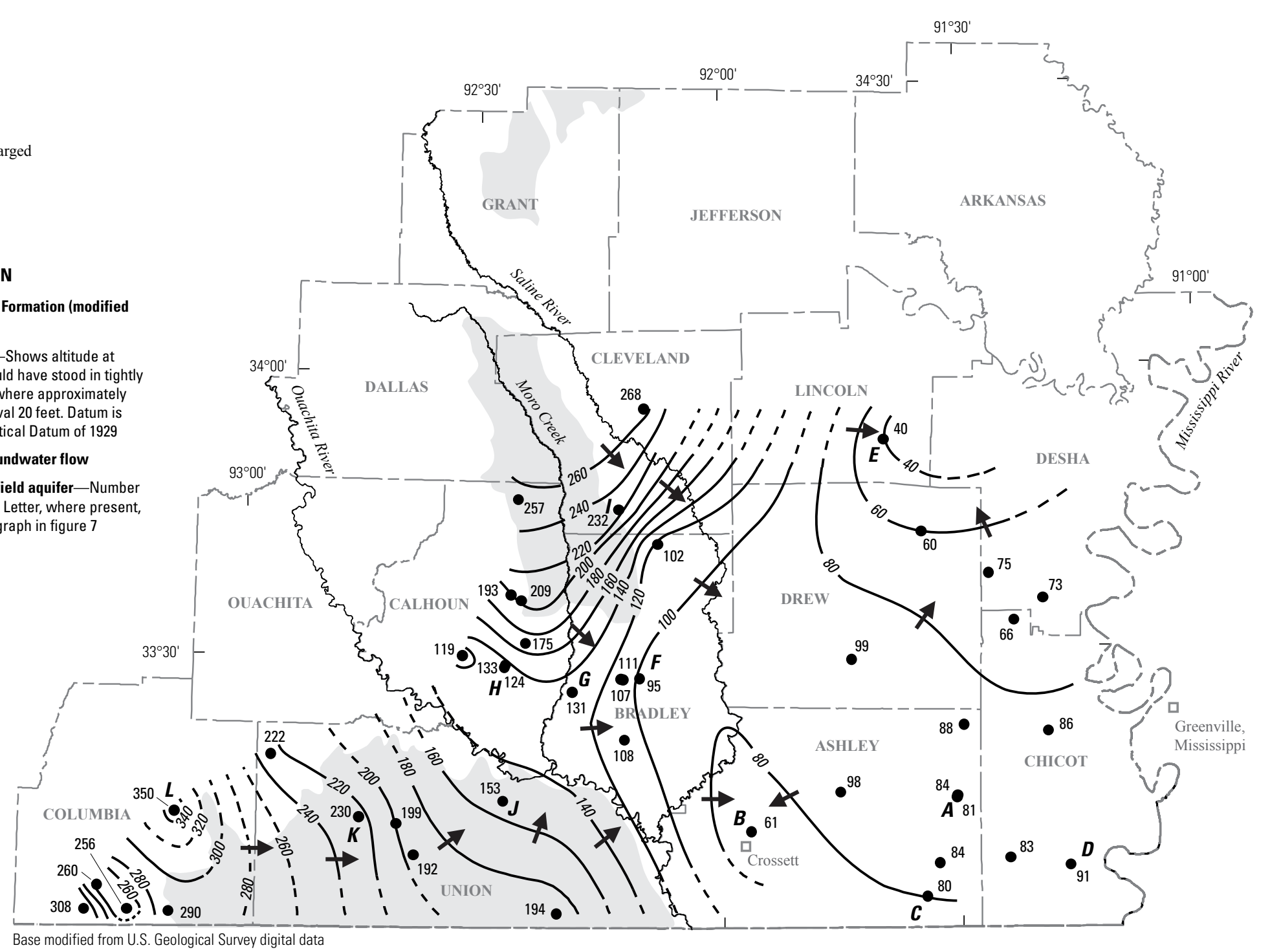

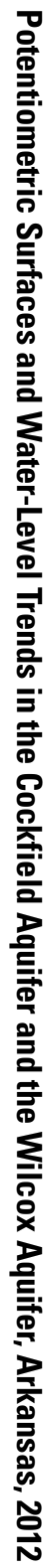

Figure 5. Potentiometric surface of the Cockfield aquifer in southern Arkansas, 2012. 


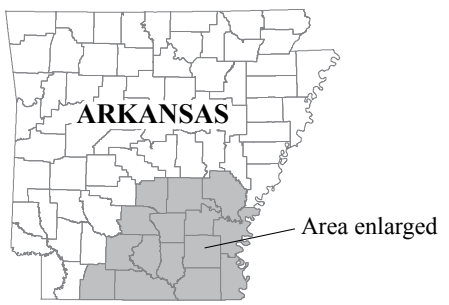

\section{EXPLANATION}

Outcrop of Cockfield Formation (modified from Hosman, 1988)

$\Delta \quad$ Well completed in Cockfield aquifer-Value is rise in water level from 2006 to 2012, in feet. Symbols are scaled to value $\begin{array}{cc}\nabla & \text { Well completed in Cockfield aquifer-Value } \\ -1.7 & \text { is decline in water level from } 2006 \text { to } 2012,\end{array}$ in feet. Symbols are scaled to value

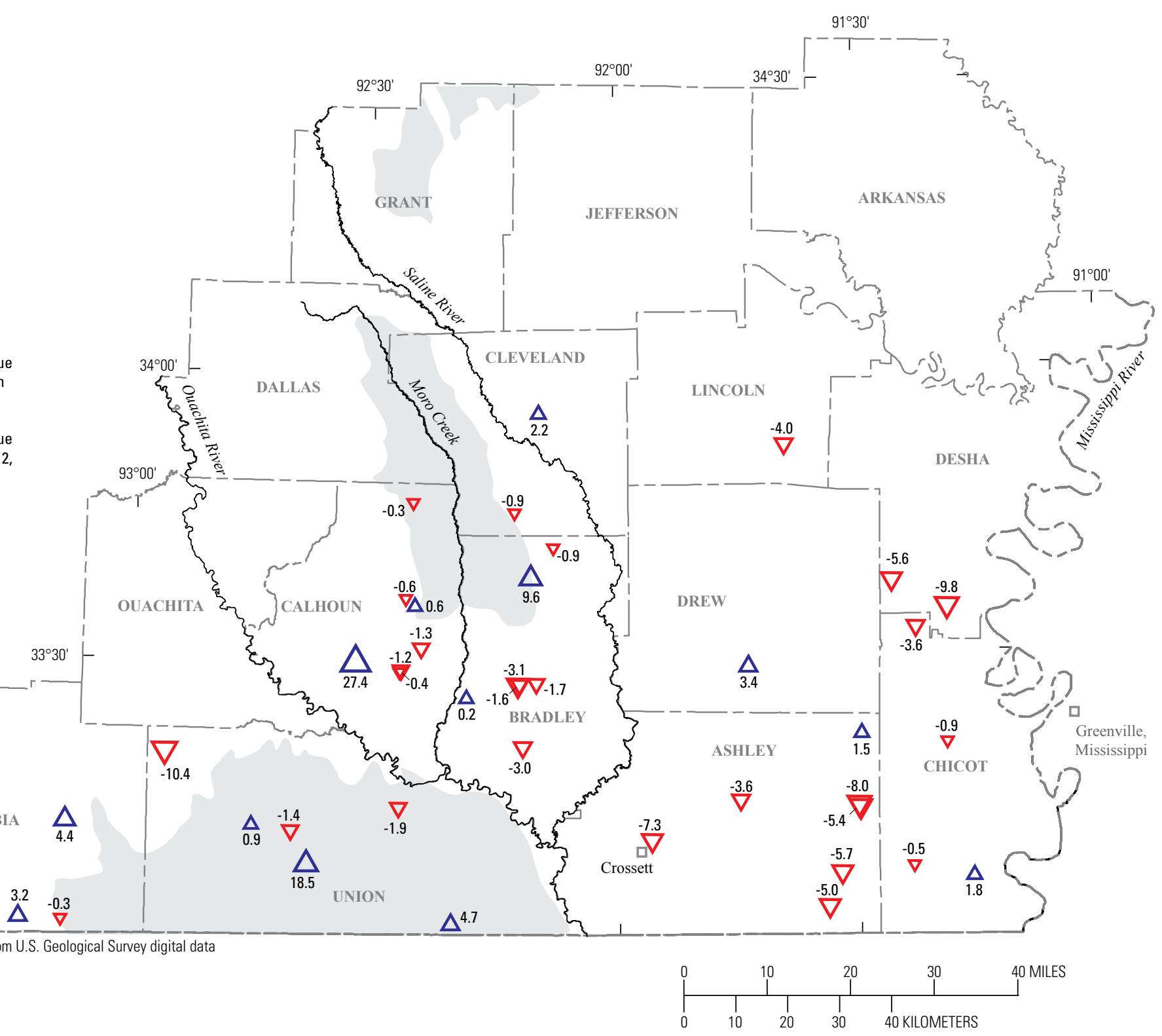

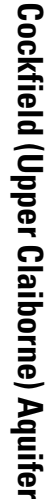

Figure 6. Water-level difference for the Cockfield aquifer in southern Arkansas, 2006-12. 


\section{Long-Term Hydrographs}

Two methods were used to evaluate long-term water-level trends for the Cockfield aquifer in Arkansas. The first method was to use the hydrograph for a well with a minimum of 20 years of record and plot the water levels in relation to time. Hydrographs of selected wells are shown in figure $7 A-L$. The selected well locations are plotted on figure 5 . The second method evaluated the annual rise or decline in water levels over a 20-year or more period through 2012, using the line of best fit $(\mathrm{Y}=\mathrm{MX}+\mathrm{B})$ and residual $\left(\mathrm{R}^{2}\right)$. The coefficient of determination $\left(\mathrm{R}^{2}\right)$ is a measure of how close the data are to the line of best fit.

Hydrographs for 32 wells with historical water-level data in the Cockfield aquifer with a minimum of 20 years of waterlevel data were constructed and evaluated. The annual rise or decline in water levels was aggregated by county. The values for the range, mean, and median of water-level change were computed for each county (table 2).

Analysis of selected hydrographs is divided into three geographic regions: the area east of the Saline River (Ashley, Chicot, Desha, Drew, Lincoln, and part of Cleveland Counties), the area between the Saline and Ouachita Rivers (Bradley, Calhoun, and part of Cleveland Counties), and the area west of the Ouachita River (Columbia and Union Counties). The area east of the Saline River is confined by the overlying Jackson Group. The central area between the Saline and Ouachita Rivers is a mixed area, the northern part is an outcrop area, the eastern part is confined by the Jackson Group, and the southern part underlies Quaternary-age terrace deposits. The area west of the Ouachita River is in an outcrop area with overlying Quaternary-age terrace deposits.

Hydrographs for wells located in Ashley, Chicot, and Lincoln Counties, east of the Saline River and screened within the confined part of the Cockfield aquifer, are shown in figures $7 A-E$. These hydrographs indicate changes in water levels ranging from a rise of approximately $0.5 \mathrm{ft}$ (well $18 \mathrm{~S} 02 \mathrm{~W} 25 \mathrm{ABB} 3$, fig. $7 D$ ) to a decline of approximately $57 \mathrm{ft}$ (well 10S05W06CAC1, fig. 7E) over the period of record.

Hydrographs for wells located in Bradley, Calhoun, and part of Cleveland Counties, the area between the Saline and Ouachita Rivers, are shown in figures $7 F-I$. These wells are screened in confined and unconfined areas of the Cockfield aquifer. The hydrographs indicate rises and declines in water levels ranging from a decline of approximately $23 \mathrm{ft}$ (well 14S10W31DBA1, fig 7F) to a rise of approximately $1 \mathrm{ft}$ (well $15 \mathrm{~S} 12 \mathrm{~W} 11 \mathrm{CAB} 1$, fig. $7 G$ ) over the period of record.

Hydrographs for wells located in Union and Columbia Counties, the area west of the Ouachita River, are shown in figures $7 J-L$. The hydrographs indicate rises and declines over the period of record from a decline of approximately $5 \mathrm{ft}$ (well 17S16W33BBA2, fig. $7 \mathrm{~K}$ ) to a rise of approximately $2 \mathrm{ft}$ (well 17S13W17DDC1, fig. 7J).

Hydrographs for the 32 wells with historical waterlevel data were evaluated using linear regression to calculate the annual rise or decline for each well, and the data were aggregated by county and statistically evaluated for the range, mean, and median of water-level change in each county (table 2). Cleveland and Lincoln Counties had only one well with a minimum of 20 years of record. Annual rise or decline calculations associated with wells with more than 20 years of record in Ashley and Chicot Counties indicated a decline in water levels. Bradley, Calhoun, Columbia, and Union Counties indicate rising and declining water levels. The mean annual water-level rise or decline for Calhoun County was $0.00 \mathrm{ft} / \mathrm{yr}$ or unchanged. The mean annual water-level data for Ashley, Bradley, Chicot, Cleveland, Columbia, Lincoln, and Union Counties show declines ranging from -0.02 to $-1.10 \mathrm{ft} / \mathrm{yr}$. 

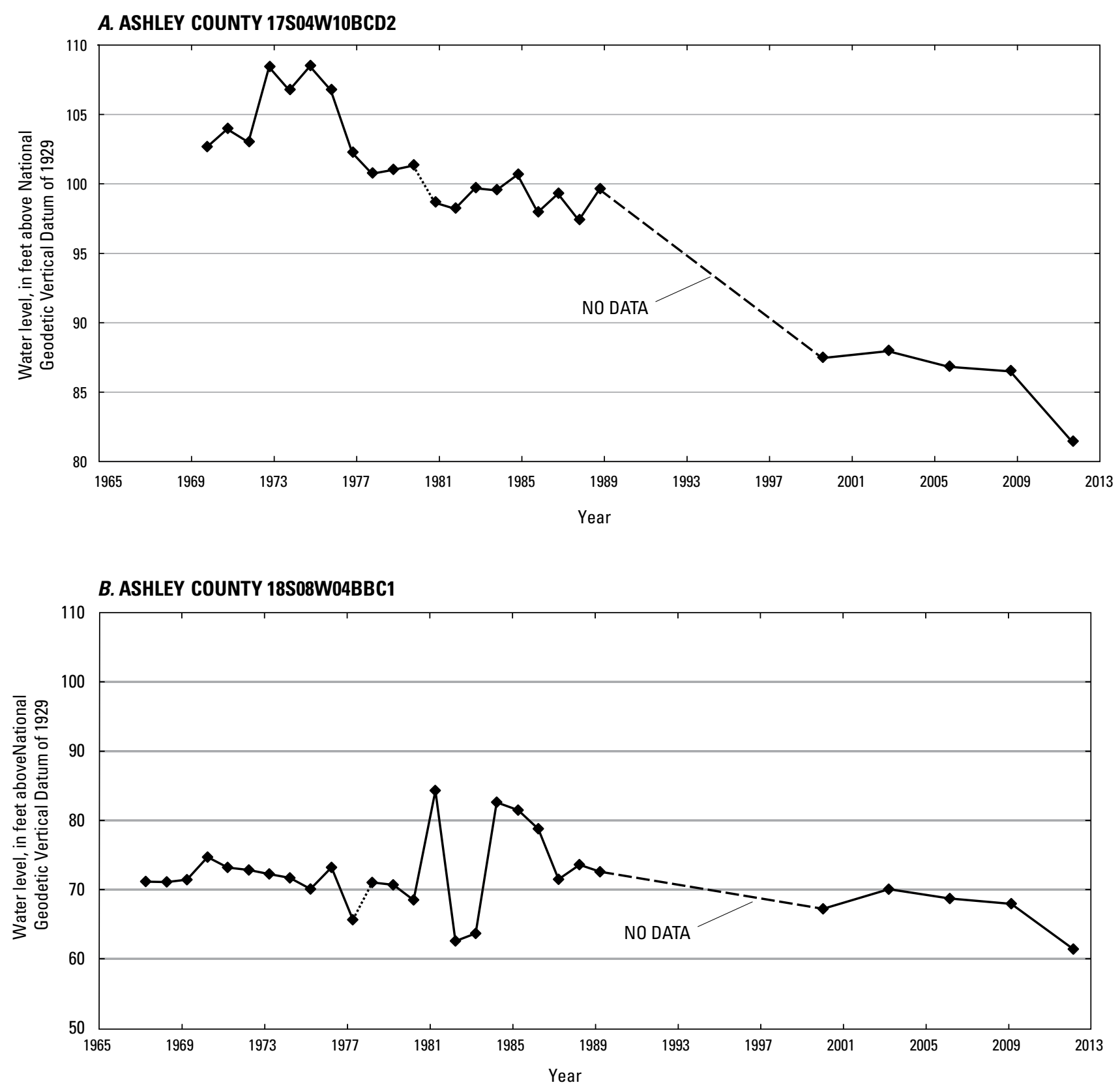

Figure 7. Water-level hydrographs for selected wells completed in the Cockfield aquifer in southern Arkansas. 


\section{ASHLEY COUNTY 19S05W12CAC1}

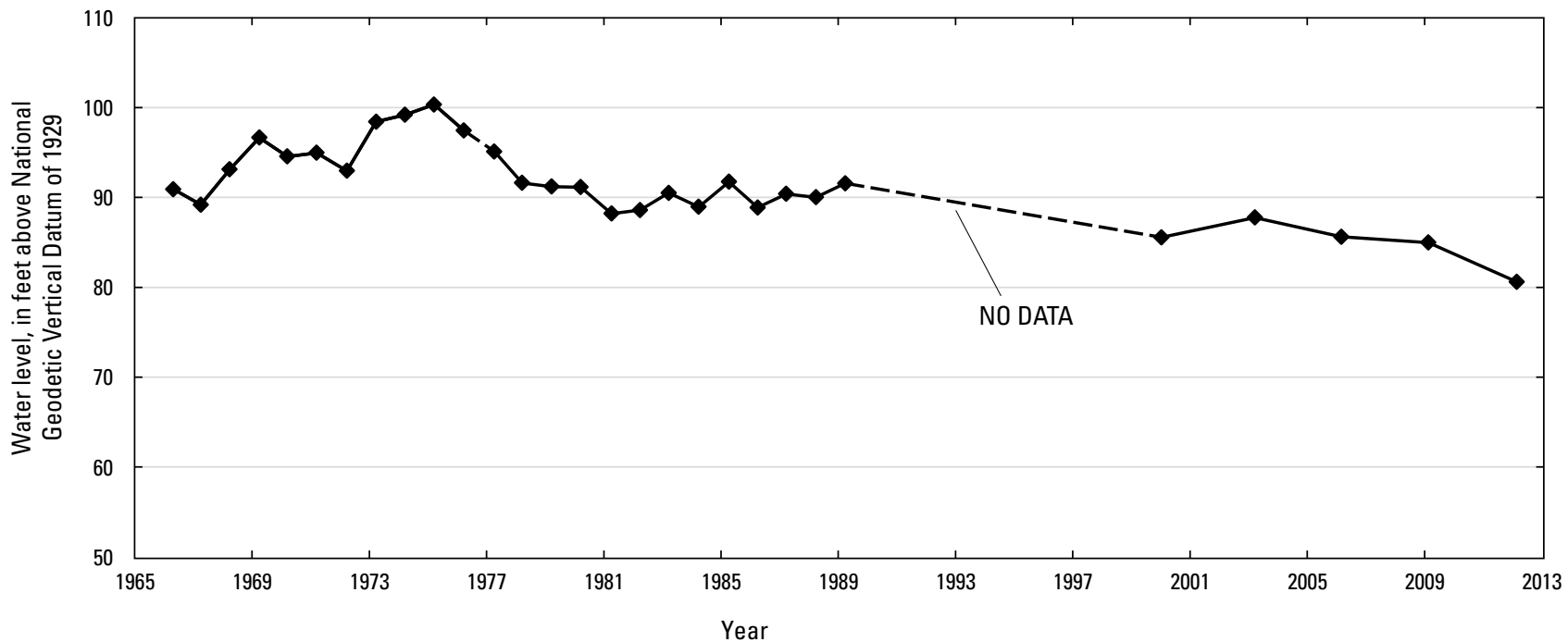

\section{CHICOT COUNTY 18S02W25ABB3}

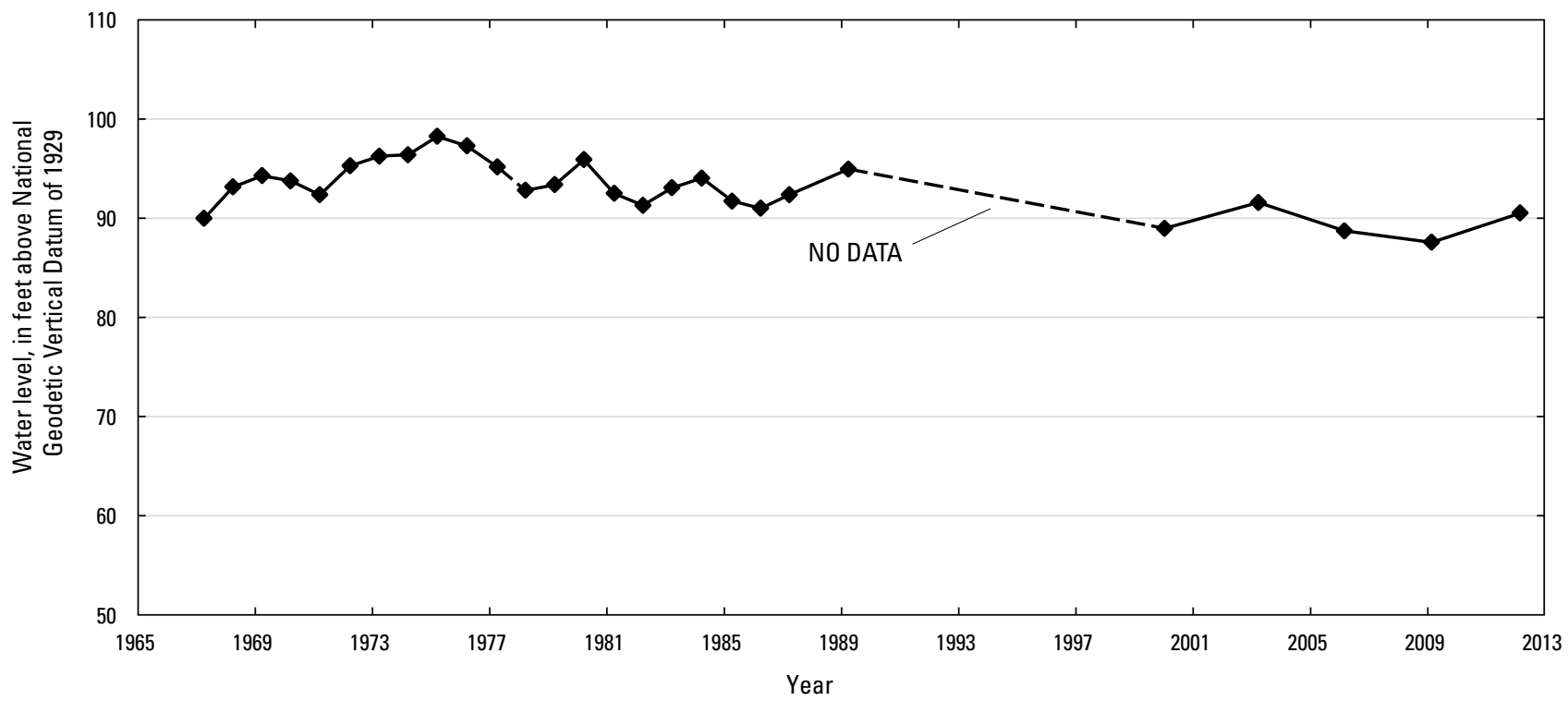

Figure 7. Water-level hydrographs for selected wells completed in the Cockfield aquifer in southern Arkansas.—Continued 


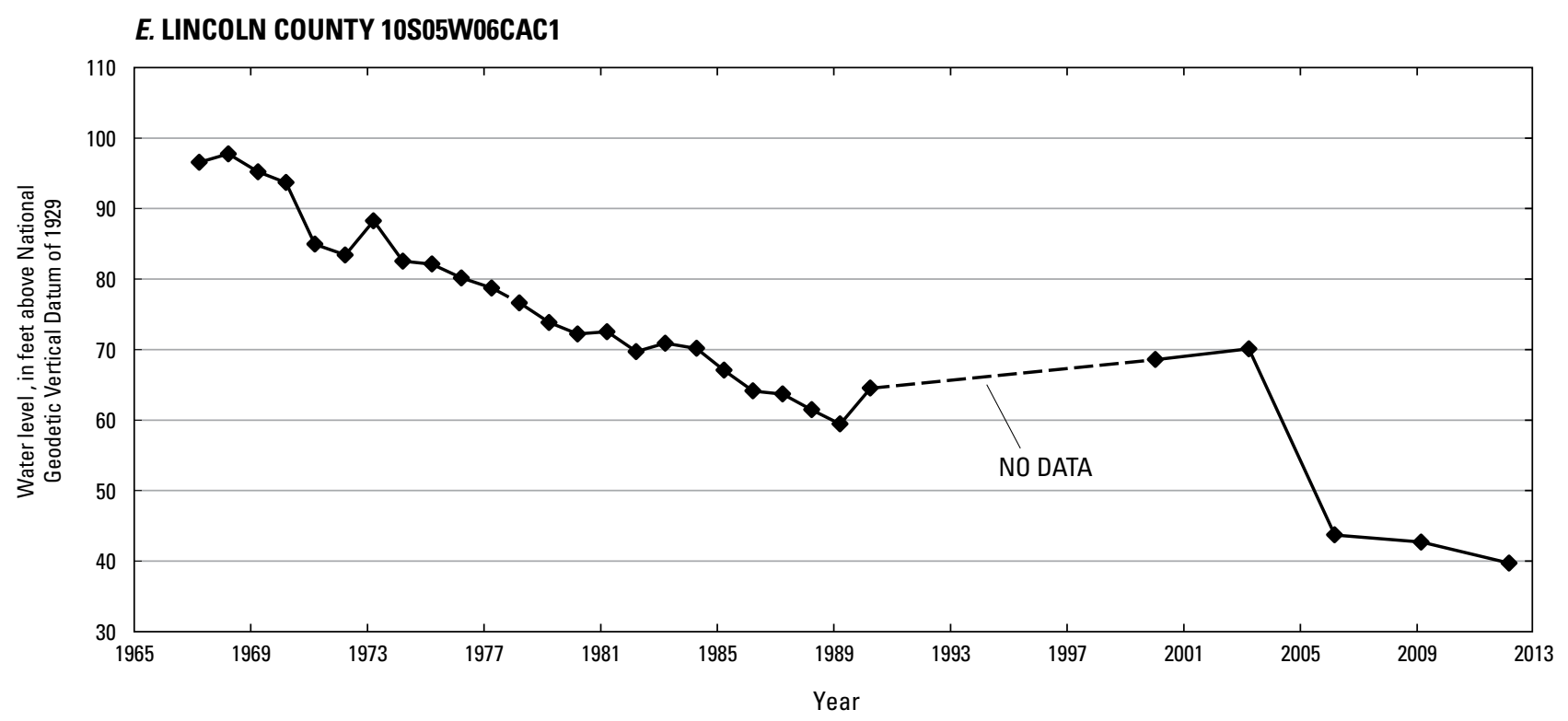

\section{F. BRADLEY COUNTY 14S10W31DBA1}

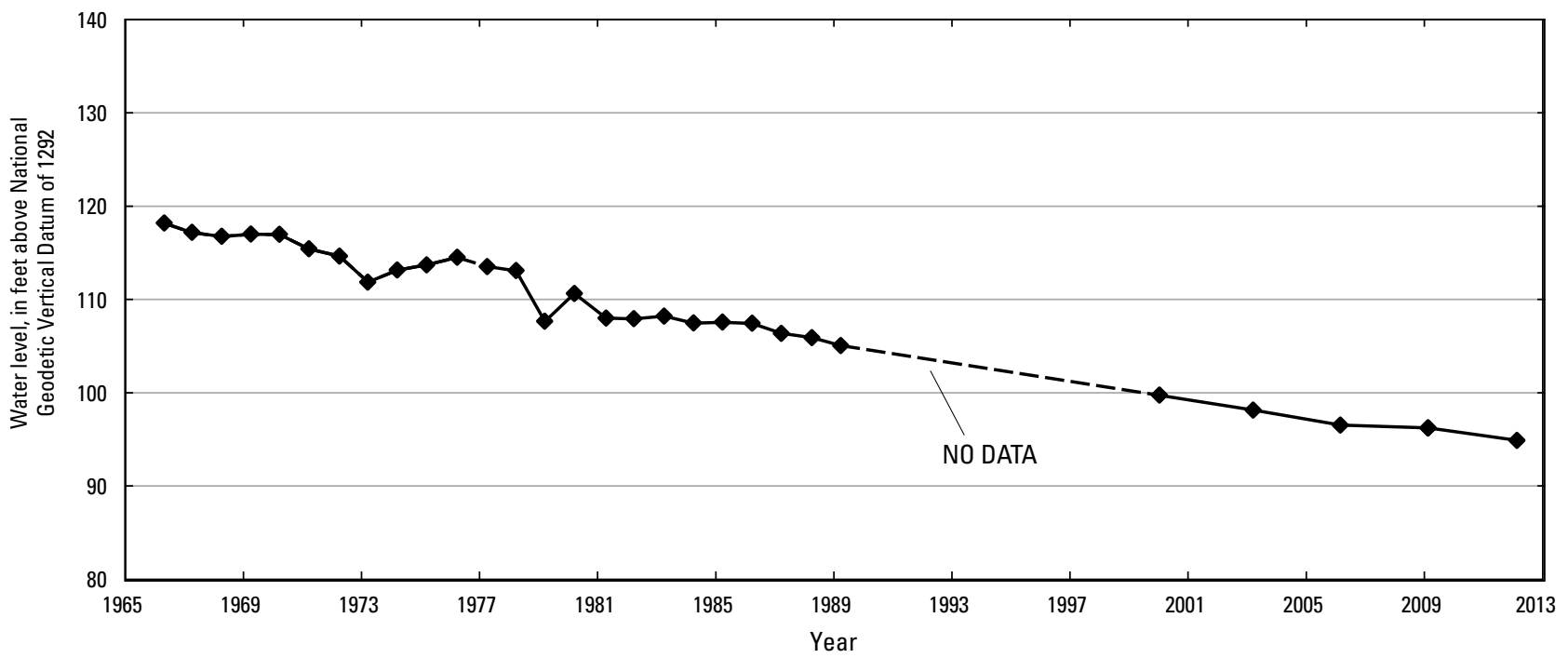

Figure 7. Water-level hydrographs for selected wells completed in the Cockfield aquifer in southern Arkansas.-Continued 


\section{G. BRADLEY COUNTY 15S12W11CAB1}

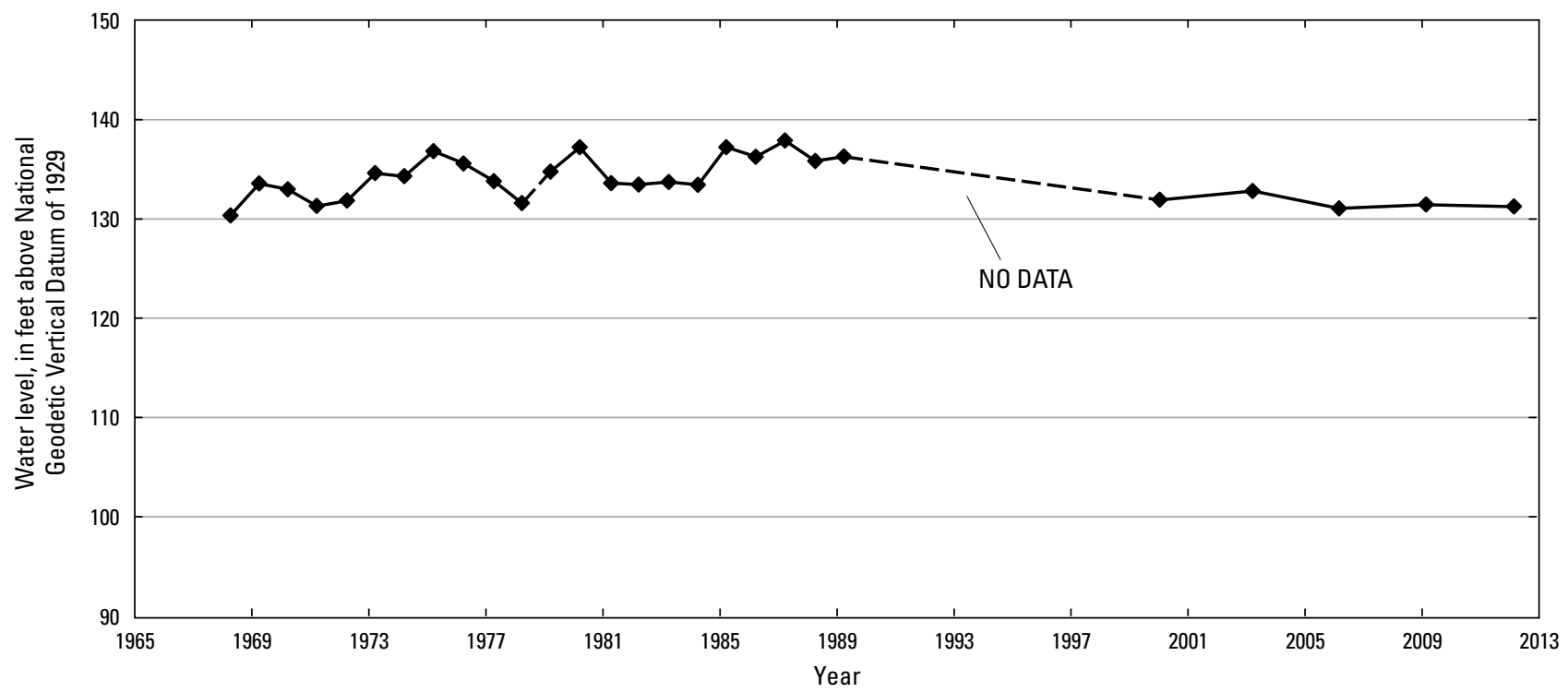

\section{H. CALHOUN COUNTY 14S13W29ADA1}

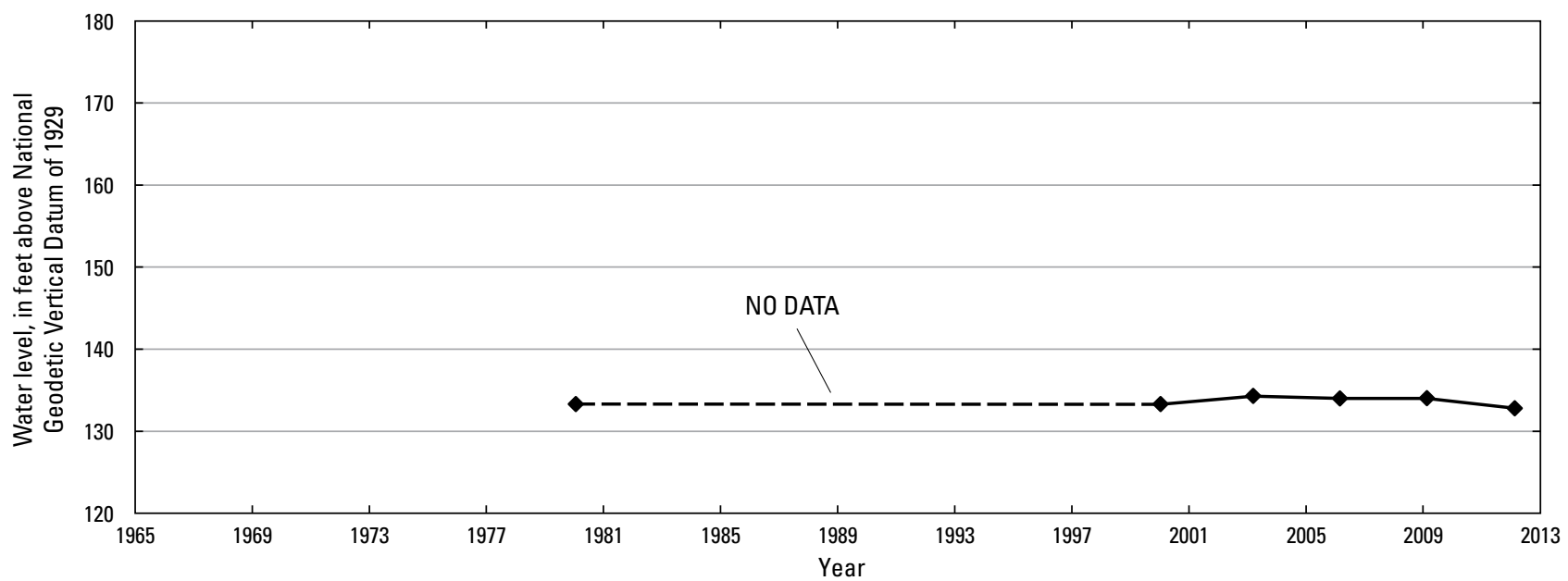

Figure 7. Water-level hydrographs for selected wells completed in the Cockfield aquifer in southern Arkansas.—Continued 
I. CLEVELAND COUNTY 11S11W23BBD1

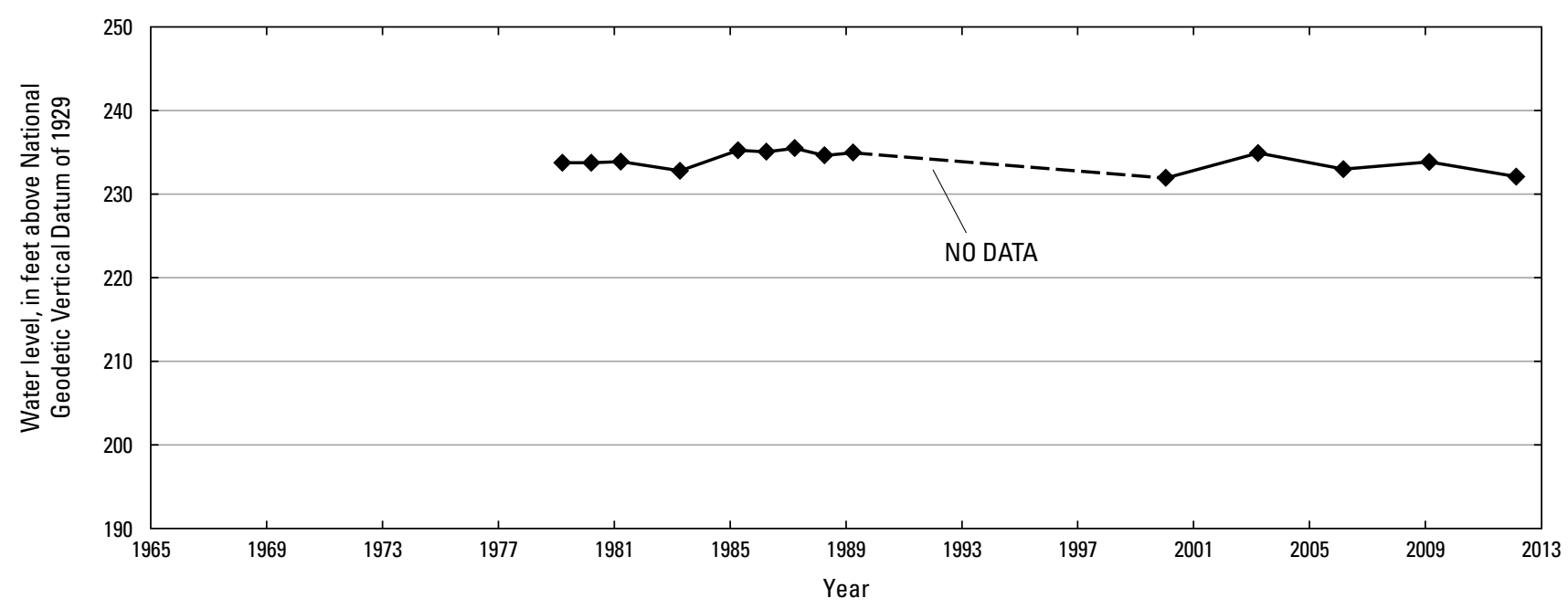

J. UNION COUNTY 17S13W17DDC1

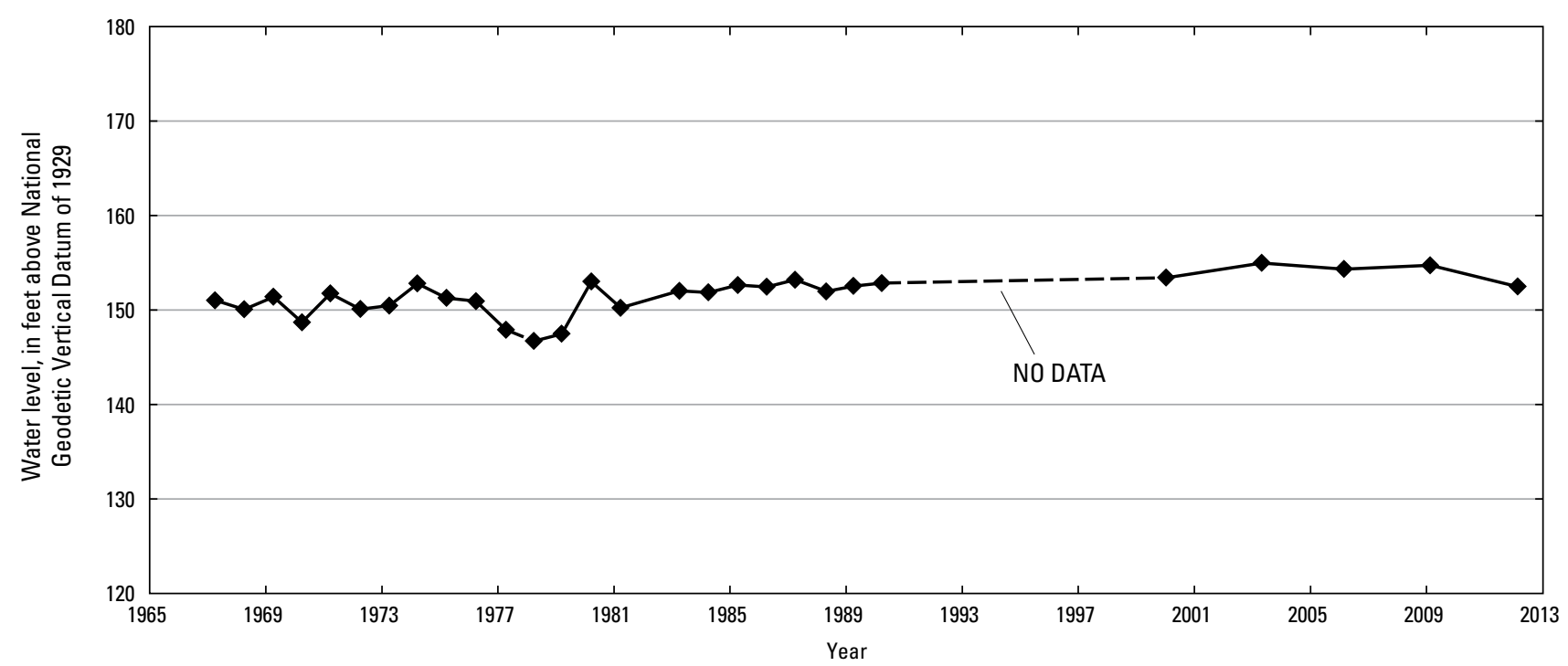

Figure 7. Water-level hydrographs for selected wells completed in the Cockfield aquifer in southern Arkansas.-Continued 


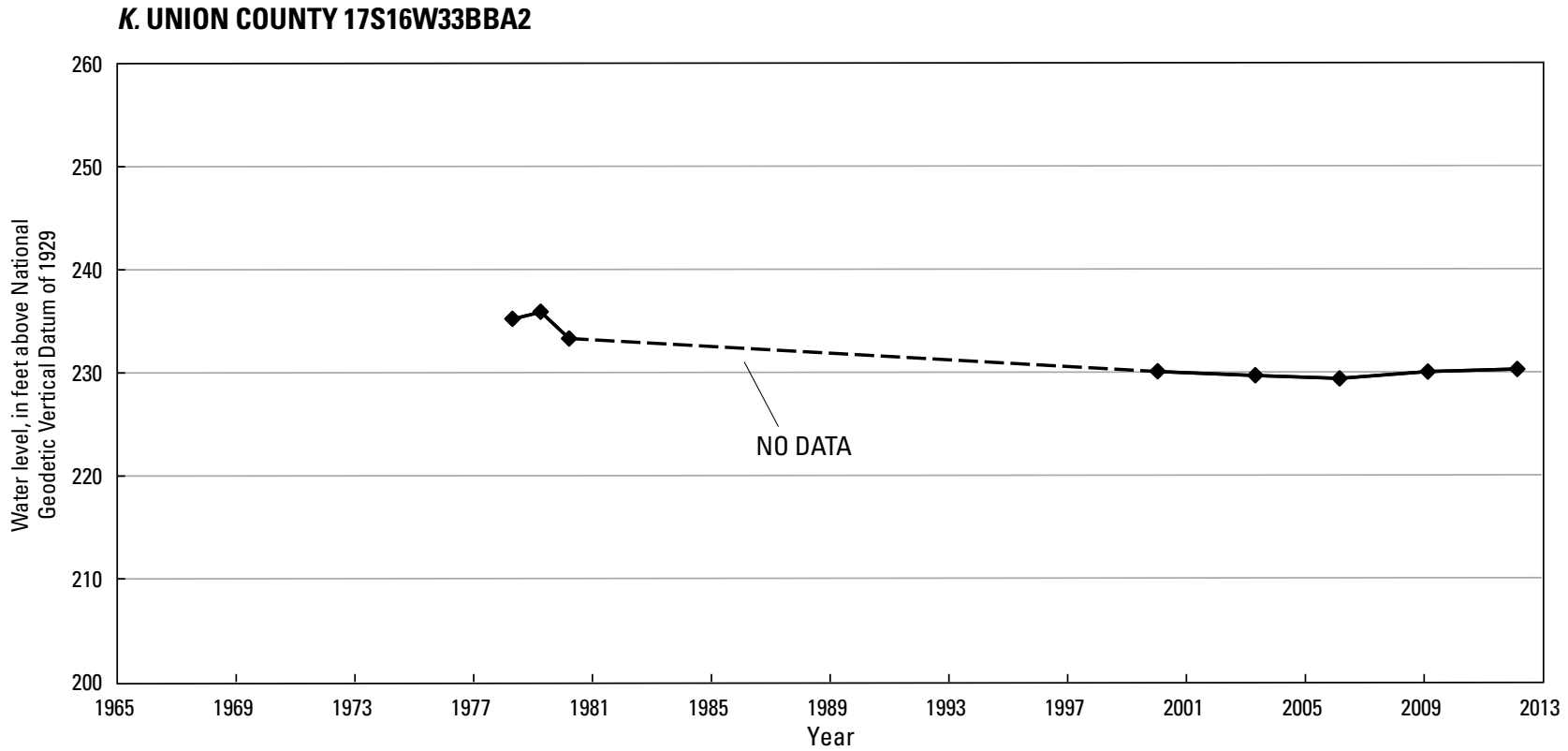

\section{COLUMBIA COUNTY 17S20W35BBD1}

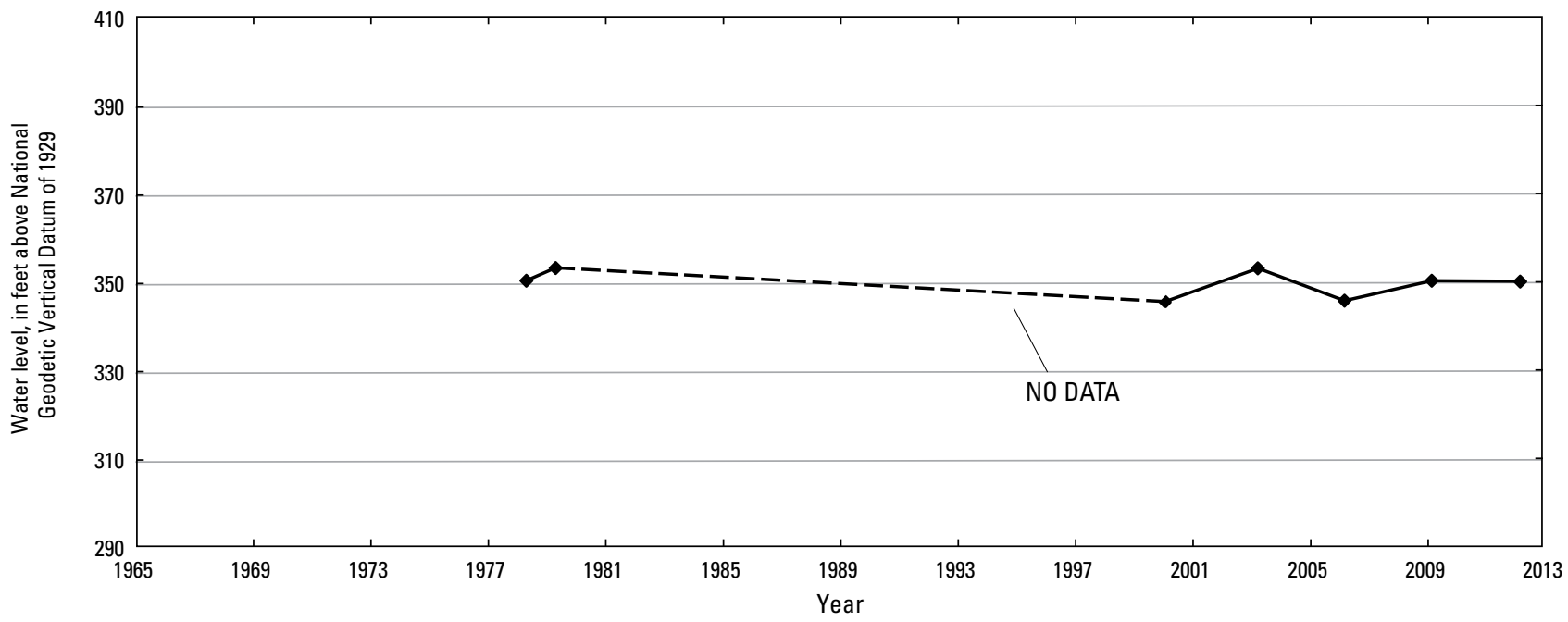

Figure 7. Water-level hydrographs for selected wells completed in the Cockfield aquifer in southern Arkansas.-Continued 
Table 2. Range, mean, and median of annual rise or decline in water level by county for wells with 20 or more years of record completed in the Cockfield aquifer in Arkansas.

[Annual rise or decline in water level for each well is calculated using linear regression; negative value indicates decline; positive value indicates rise; $\mathrm{R}^{2}$, coefficient of determination]

\begin{tabular}{|c|c|c|c|c|c|}
\hline County & $\begin{array}{l}\text { Number } \\
\text { of wells }\end{array}$ & $\begin{array}{l}\text { Range of values of } \\
\text { annual rise }(+) \text { or } \\
\text { decline }(-) \text { in } \\
\text { water level } \\
\text { (feet/year) }\end{array}$ & $\begin{array}{c}\text { Mean annual rise (+) } \\
\text { or decline }(-) \text { in } \\
\text { water level } \\
\text { (feet/year) }\end{array}$ & $\begin{array}{c}\text { Median annual rise (+) } \\
\text { or decline }(-) \text { in } \\
\text { water level } \\
\text { (feet/year) }\end{array}$ & $\begin{array}{l}\text { Range of } R^{2} \text { values } \\
\text { for trend lines }\end{array}$ \\
\hline Ashley & 6 & -0.55 to -0.11 & -0.32 & -0.31 & 0.08 to 0.90 \\
\hline Bradley & 4 & -0.51 to 0.40 & -0.04 & -0.03 & 0.04 to 0.97 \\
\hline Calhoun & 6 & -0.11 to 0.22 & 0.00 & -0.01 & 0.07 to 0.70 \\
\hline Chicot & 3 & -0.33 to -0.11 & -0.19 & -0.15 & 0.40 to 0.70 \\
\hline Cleveland & 1 & -0.04 & -0.04 & -0.04 & 0.16 \\
\hline Columbia & 5 & -0.11 to 0.04 & -0.02 & 0.01 & 0.01 to 0.26 \\
\hline Lincoln & 1 & -1.10 & -1.10 & -1.10 & 0.84 \\
\hline Union & 6 & -0.18 to 0.11 & -0.03 & -0.02 & 0.001 to 0.85 \\
\hline
\end{tabular}

\section{Wilcox (Lower Wilcox) Aquifer}

\section{Hydrogeologic Setting}

The Wilcox aquifer, in northeastern and southern Arkansas, is composed of the Wilcox Group and is distributed throughout the Mississippi Embayment. The Wilcox Group is part of a syncline approximately centered beneath the Mississippi River that plunges to the south-southeast (fig. 3). In the northeast part of Arkansas, the Wilcox Group is composed of three units: the Flour Island Formation, the Fort Pillow Sand, and the Old Breastworks Formation; in southern Arkansas, the formation is undifferentiated (table 1). In central Arkansas, the Wilcox aquifer is not extensively used, and water-level data are not sufficient to determine potentiometric surfaces. Because of the discontinuous nature of water-level data, the potentiometric-surface map of the Wilcox aquifer is divided into two areas - one in northeastern Arkansas and the second in southern Arkansas.

The Wilcox Group is composed of thin interbedded layers of lignitic sand and clays in most of the northeastern area. The Wilcox Group crops out at or near Crowleys Ridge in Clay, Craighead, and Greene Counties (Broom and Lyford, 1981). East of Crowleys Ridge, the Wilcox Group (including the Fort Pillow Sand and the Old Breastworks Formation) contains a sand bed $200 \mathrm{ft}$ or more in thickness (Petersen and others, $1985)$ in the middle to lower part of the unit which is referred to as the "1,400-foot sand" (Ryling, 1960; Plebuch, 1961) or the "lower Wilcox aquifer" (Hosman and others, 1968).
In northeastern Arkansas, the Wilcox aquifer is overlain by a clay bed of the Wilcox Group and is underlain by a clay bed of the Wilcox Group or the Midway Group. Part of the Wilcox aquifer, within Crowleys Ridge, is perched and hydrologically separated from the aquifer in the surrounding Mississippi Alluvial Plain (fig. 1) (Petersen and others, 1985).

The Wilcox Group is composed of interbedded layers of clay, sandy clay, sand, and lignite in the southern area. The Wilcox Group overlies the Midway Group and underlies Quaternary-age terrace deposits and alluvium or crops out. The outcrop is generally thin and discontinuous over large areas. Downslope from the outcrop, the Wilcox Group becomes thicker, ranging from a few feet in the outcrop areas to about $750 \mathrm{ft}$ at the center of the syncline (Albin, 1964).

Recharge to the Wilcox aquifer in the northeastern area occurs through infiltration of precipitation in outcrop areas along the western side of Crowleys Ridge. Discharge occurs mainly through well withdrawals (Westerfield, 1994). The depth of wells in this area ranged from $462 \mathrm{ft}$ in Greene County to $1,885 \mathrm{ft}$ in Lee County. Well yield ranged from 100 to 2,000 gal/min (Schrader and Joseph, 2000).

Recharge to the Wilcox aquifer in the southern area occurs through infiltration of precipitation in outcrop areas and inflow from overlying alluvial and terrace deposits. Discharge occurs from flows into overlying formations, into streams in the outcrop area, and to wells (Westerfield, 1994). Well depths ranged from $14 \mathrm{ft}$ within the recharge area in Hempstead County to $533 \mathrm{ft}$ in Ouachita County. Well yields ranged from 10 to $100 \mathrm{gal} / \mathrm{min}$ (Schrader and Joseph, 2000). 


\section{Hydraulic Properties}

Values for specific capacity and transmissivity vary within the Wilcox aquifer. Pugh (2008) reported the following values based on multiple-well aquifer tests and single-well pump tests. Specific capacity values ranged from 0.25 (gal/ $\mathrm{min}) / \mathrm{ft}$ to $641(\mathrm{gal} / \mathrm{min}) / \mathrm{ft}$ with a median of $21.1(\mathrm{gal} / \mathrm{min}) / \mathrm{ft}$. Transmissivity values ranged from $30 \mathrm{ft}^{2} / \mathrm{d}$ to $32,000 \mathrm{ft}^{2} / \mathrm{d}$ with a median of $8,170 \mathrm{ft}^{2} / \mathrm{d}$ and a mean of $10,700 \mathrm{ft}^{2} / \mathrm{d}$. Hydraulic conductivity values could not be determined based on well tests completed in the Wilcox aquifer. Pugh (2008) calculated an estimated hydraulic conductivity value of $9.7 \mathrm{ft} / \mathrm{d}$ for the Wilcox aquifer by dividing the mean transmissivity value $\left(10,700 \mathrm{ft}^{2} / \mathrm{d}\right)$ by the maximum aquifer thickness $(1,100 \mathrm{ft})$.

\section{Water Use}

The majority of water withdrawals from the Wilcox aquifer were for industrial and public supply. Withdrawals for agricultural, commercial, and domestic use were less than those for industrial and public supply but important locally. Reported withdrawals from the Wilcox aquifer in Arkansas totaled $36.5 \mathrm{Mgal} / \mathrm{d}$ during 2010 (fig. 8), most of which occurred in the northeastern study area (Terrance W. Holland, U.S. Geological Survey, written commun., 2012). Withdrawals from 1975 through 2005 remained relatively constant, between $21.0 \mathrm{Mgal} / \mathrm{d}$ and $27.0 \mathrm{Mgal} / \mathrm{d}$, with the exception of 1990 and 1995 when $30.9 \mathrm{Mgal} / \mathrm{d}$ and $41.0 \mathrm{Mgal} / \mathrm{d}$ were withdrawn, respectively. The rise in water use from 1990 to 1995 was

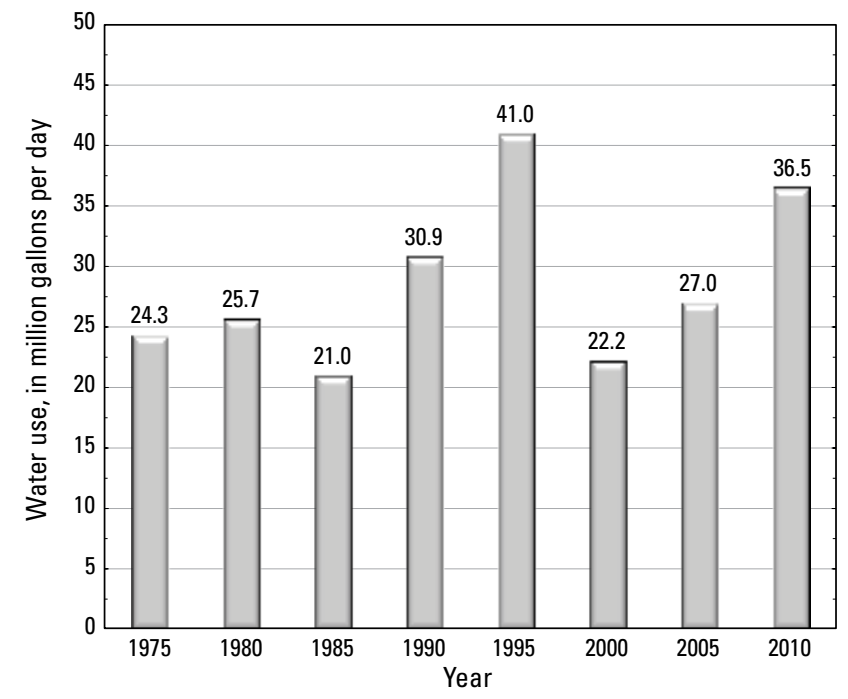

Data compiled from Halberg and Johnson (1977), Holland and Ludwig (1981), and Holland (1987, 1993, 1999, 2004, 2007, Terrance W. Holland, U.S. Geological Survey, written commun., 2010)

Figure 8. Water use from the Wilcox aquifer in Arkansas, 1975-2010. attributed to withdrawals by a power generation plant that was operating during this time period (Terrance W. Holland, U.S. Geological Survey written commun., 2009). The rise in water use from 2005 to 2010 was attributed to increased withdrawals for industry, irrigation, and public supply (Aaron L. Pugh, U.S. Geological Survey written commun., 2014). In the northeastern area, the majority of water withdrawn from the Wilcox aquifer was for public supply. The aquifer is also an important source of water locally for agricultural, commercial, and domestic use. In the southern area, the majority of water withdrawn from the aquifer was for domestic use.

\section{Potentiometric Surface}

Two potentiometric-surface maps, one for the northeastern area and one for the southern area, show the altitude of the water surface in the Wilcox aquifer (figs. 9 and 10). The maps were constructed using water-level data collected in February and March 2012 from 47 wells; 31 wells in the northeastern area (app. 3) and 16 wells in the southern area (app. 4).

The direction of groundwater flow in the Wilcox aquifer in the northeastern area in 2012 (fig. 9) was towards the southsouthwest except for some areas immediately adjacent to the Mississippi River where the flow was more eastward towards the river. Groundwater withdrawals have altered the direction of flow near West Memphis (Joseph, 1998). The highest waterlevel altitude was $219 \mathrm{ft}$ in northern Mississippi County, and the lowest water-level altitude was $123 \mathrm{ft}$ near West Memphis in Crittenden County. In Greene County, a water-level altitude of $182 \mathrm{ft}$ was measured near Crowleys Ridge. Within Crowleys Ridge, the waters of the Wilcox aquifer are perched at higher altitudes than the surrounding Mississippi Alluvial Plain and have too few control points for contouring.

The direction of groundwater flow in the southern area (fig. 10) was generally towards the southwest in the northern part. The direction of groundwater flow in the southern part was in all directions because of two cones of depression and two water-level mounds. The cones of depression are located in southeastern Clark County and central Nevada County, and the water-level mounds are located in Hot Spring County and Hempstead County (fig. 10). The water-level mounds are the result of the higher land-surface altitudes in the outcrop area. Groundwater flow toward the cone of depression in southeastern Clark County was generally from the north, south, and west; water flows toward the cone of depression in Nevada County from all directions. Groundwater flow from the water-level mound in eastern Hot Spring County was generally to the north, south, and east; groundwater flows from the water-level mound in southern Hempstead County to the south, east, and west. The highest water-level altitude measured was $394 \mathrm{ft}$ at the centers of the water-level mounds in eastern Hot Spring County and southwestern Hempstead County. The lowest water-level altitude measured was $145 \mathrm{ft}$ at the center of the cone of depression in Clark County. 
EXPLANATION

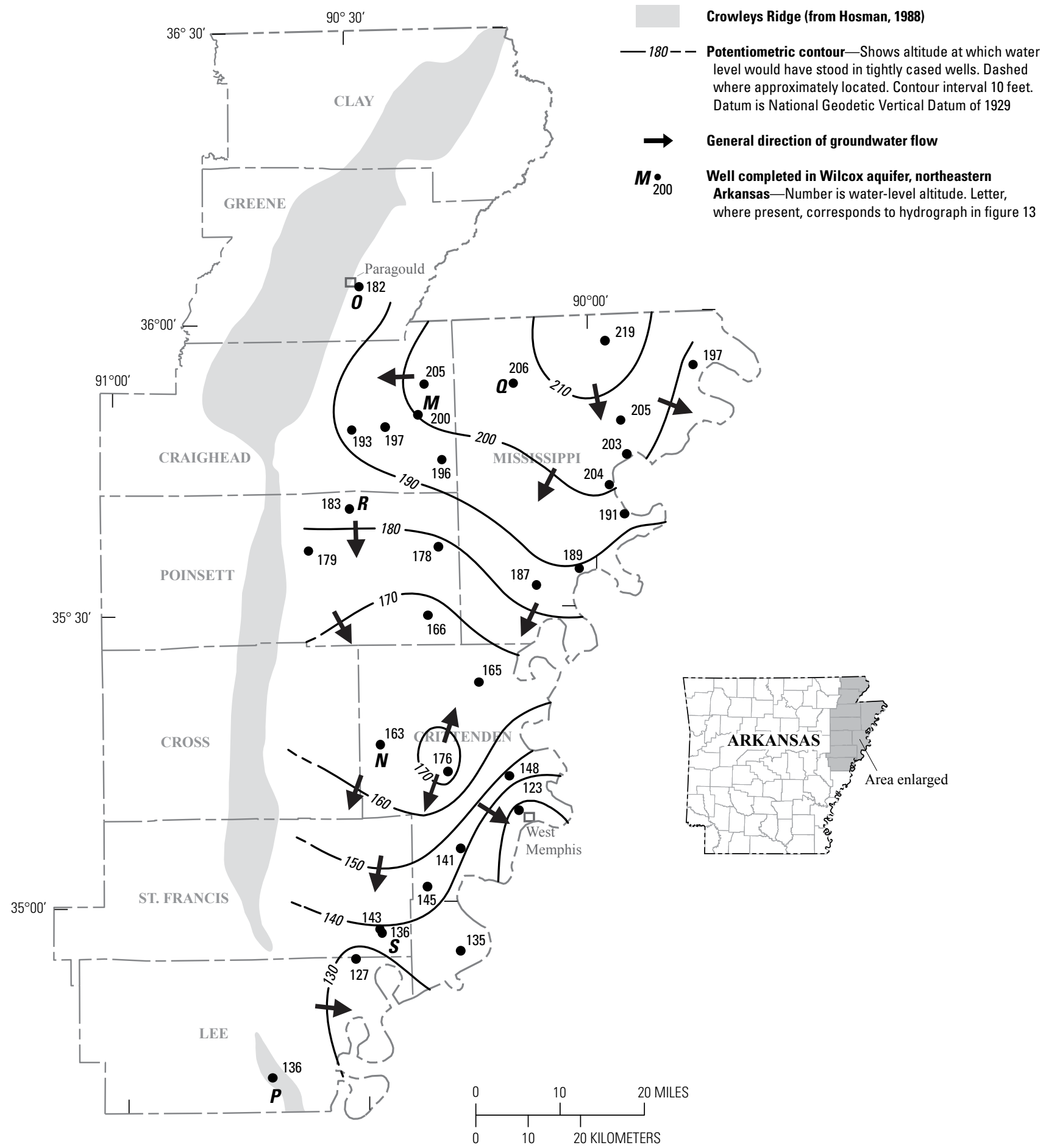

Figure 9. Potentiometric surface of the Wilcox aquifer in northeastern Arkansas, 2012. 


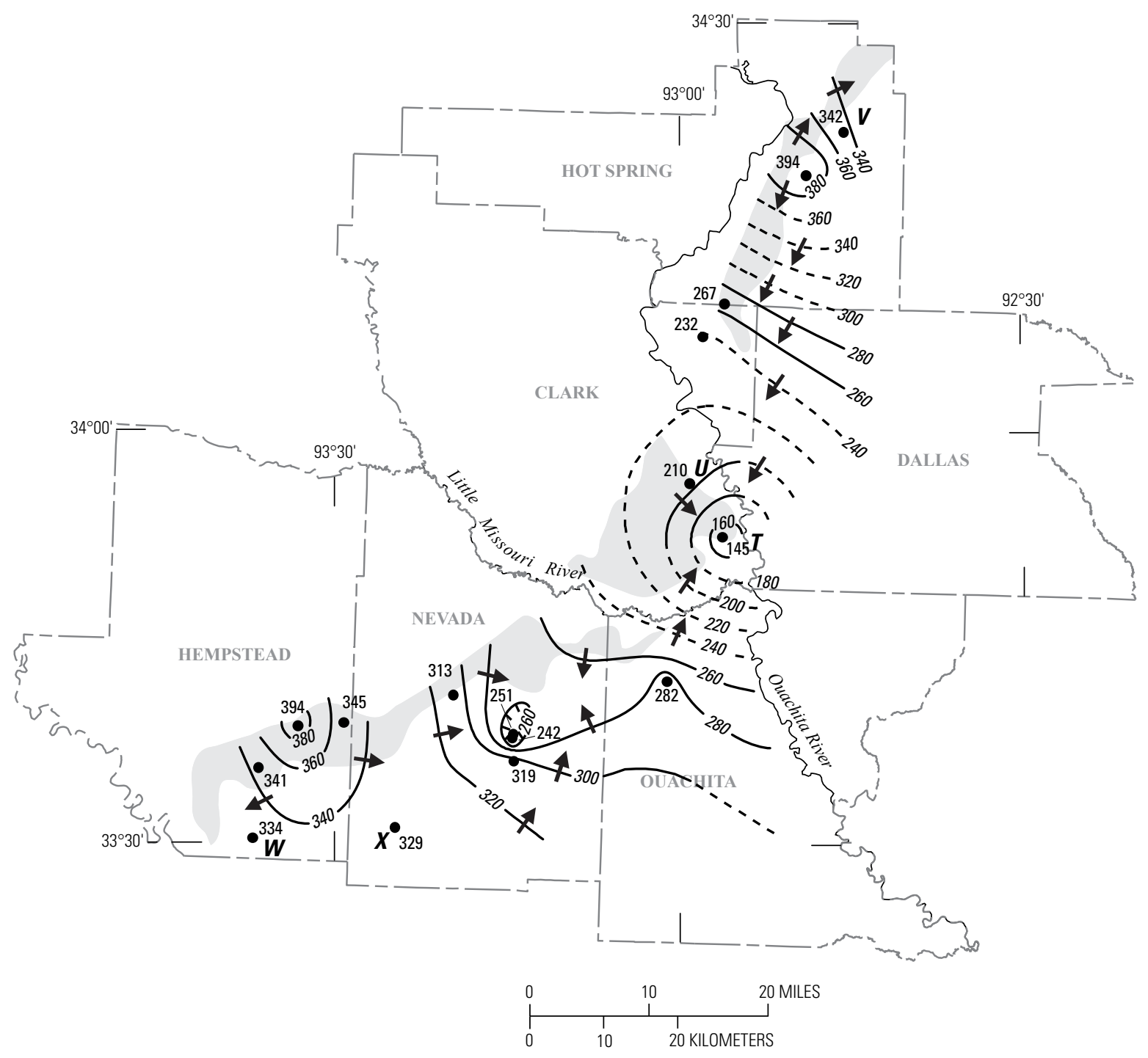

EXPLANATION

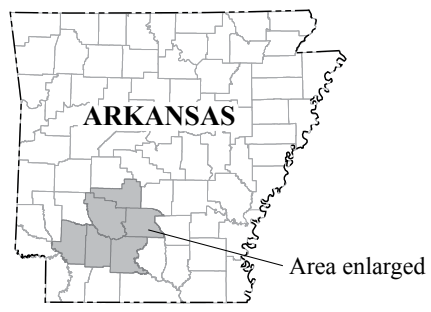

Outcrop of Wilcox Group (from Hosman, 1988)

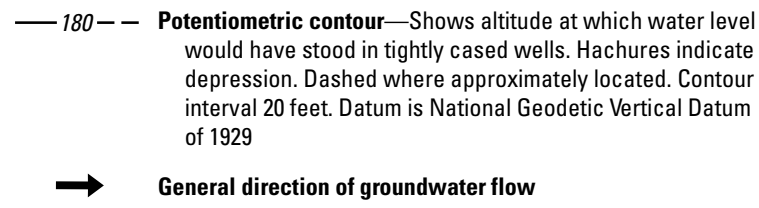

$\boldsymbol{T} \bullet \quad$ Well completed in Wilcox aquifer, southern Arkansas-Number is water-level altitude. Letter, where present, corresponds to hydrograph in figure 14

Figure 10. Potentiometric surface of the Wilcox aquifer in southern Arkansas, 2012. 


\section{Water-Level Trends}

\section{Water-Level Difference from 2006 to 2012}

Water-level difference maps (figs. 11 and 12) for the Wilcox aquifer in Arkansas were constructed using 47 waterlevel measurements made during 2006 and 2012. Difference values were obtained from water levels measured in 31 wells in the northeastern area of the Wilcox aquifer and 16 wells measured in the southern area.

The 2006 to 2012 difference in water levels for the Wilcox aquifer in the northeastern area (fig. 11, app. 5) ranged from 22.0 to $-17.9 \mathrm{ft}$. The largest rise in water levels occurred in Crittenden County, and the largest decline was in Lee County. Twenty-one wells in the northeastern area had rising water levels, and 10 wells had declining water levels. Wells in the northern part of this area had rising water levels, and wells in the southern part had declining water levels. In the central part of the area, water levels in all wells measured in Craighead County rose, and water levels rose in all but one well in Poinsett County and one well in Mississippi County. Water levels in wells in Crittenden County rose and declined. All water levels in wells measured in Lee and St. Francis Counties declined.

The 2006 to 2012 difference in water levels for the Wilcox aquifer in the southern area (fig. 12, app. 6) ranged from 18.1 to $-4.2 \mathrm{ft}$. The largest rise and the largest decline in water levels occurred in Nevada County. Water-levels rose in 12 wells in the southern area and declined in 4 wells. Water levels in wells in the northern area rose and declined in wells in the central part of the area (Clark County). Water levels in wells in the southern part of the area rose and declined.

\section{Long-Term Hydrographs}

Hydrographs for 12 wells with a minimum of 20 years of record ( 7 wells in the northeastern area and 5 wells in the southern area) were used to evaluate long-term trends of the
Wilcox aquifer. The well locations for the corresponding hydrographs are plotted on figures 9 and 10 and designated by the letters $\mathrm{M}-\mathrm{X}$ positioned next to the well. These hydrographs are shown on figure 13 (northeastern, area) and figure 14 (southern area). Hydrographs for 36 wells (24 wells in the northeastern area of the Wilcox aquifer and 12 wells in the southern area) were used to calculate the annual rise or decline in water levels over a period of 20 or more years using linear regression. The annual rise or decline in water levels was aggregated by county, and values for the range, mean, and median of water-level change were computed for each county (table 3). The summary for Greene, Lee, and St. Francis Counties was for a single well.

Selected hydrographs for the northeastern area (figs. 13M-S) all show declining water levels. Waterlevel changes in selected wells ranged from a decline of approximately $23 \mathrm{ft}$ in well 14N07E17DCB1 (fig. 7M) in Craighead County to a decline of approximately $60 \mathrm{ft}$ in well 04N06E21BAD2 (fig. 7S) in St. Francis County. Hydrographs in the southern area (figs. 14T-X) show rising and declining water levels. Water-level changes in selected wells ranged from a decline of approximately $20 \mathrm{ft}$ in well 10S18W10DDB1 (fig. 7T) in Clark County to a rise of approximately $14 \mathrm{ft}$ in well 14S22W19AAA1 (fig. $7 X$ ) in Nevada County.

Linear regression analysis of long-term hydrographs was used to determine the mean annual water-level rise and decline in the Wilcox aquifer in the northeastern and southern areas of Arkansas. In the northeastern area, the mean annual water level declined in all seven counties. The mean annual declines ranged from $-0.55 \mathrm{ft} / \mathrm{yr}$ in Craighead County to $-1.46 \mathrm{ft} / \mathrm{yr}$ in St. Francis County. Greene, Lee, and St. Francis Counties had only one well with a minimum of 20 years of record.

In the southern area, the annual rise or decline calculations for wells with over 20 years of record indicate rising and declining water levels in Clark, Hot Spring, and Nevada Counties. The mean annual water level declined in all counties except Hot Spring County. 


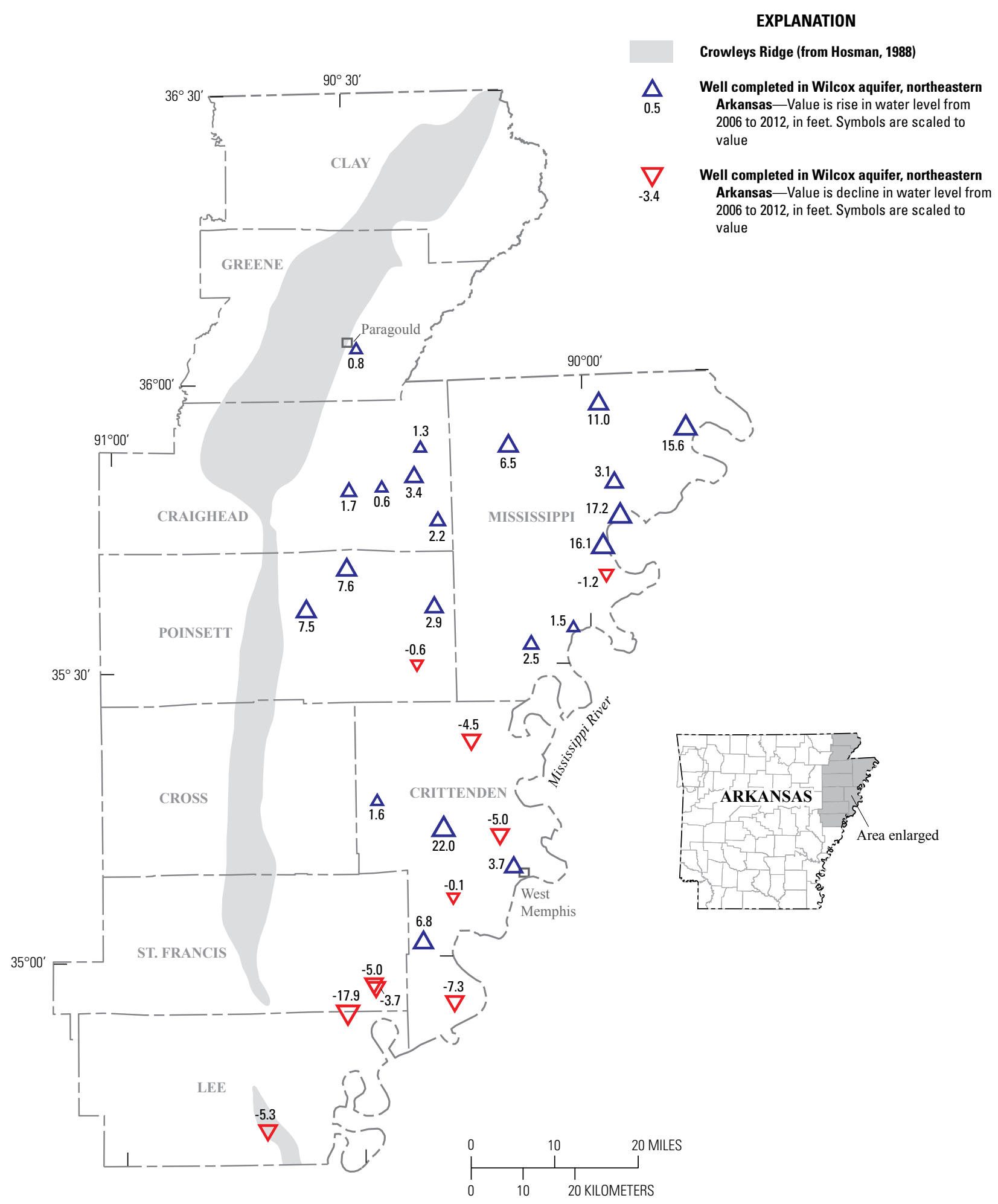

Figure 11. Water-level difference for the Wilcox aquifer in northeastern Arkansas, 2006-12. 


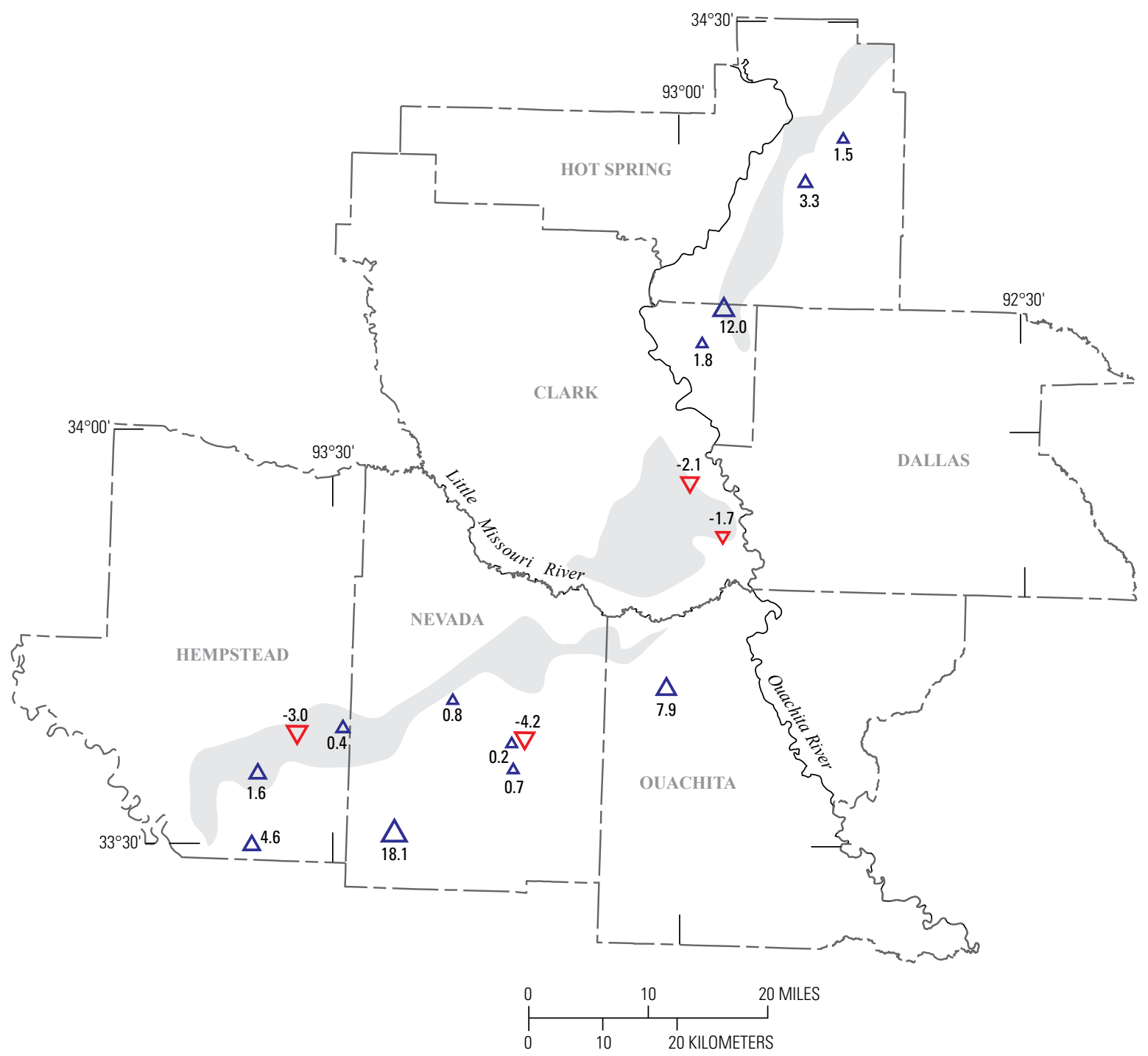

EXPLANATION

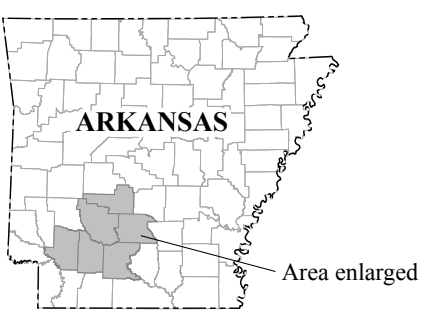

Outcrop of Wilcox Group (from Hosman, 1988)

$\Delta \quad$ Well completed in Wilcox aquifer, southern Arkansas-

Value is rise in water level from 2006 to 2012, in feet. Symbols are scaled to value

Well completed in Wilcox aquifer, southern ArkansasValue is decline in water level from 2006 to 2012, in feet. Symbols are scaled to value

Figure 12. Water-level difference for the Wilcox aquifer in southern Arkansas, 2006-12. 


\section{CRAIGHEAD COUNTY 14N07E17DCB1}

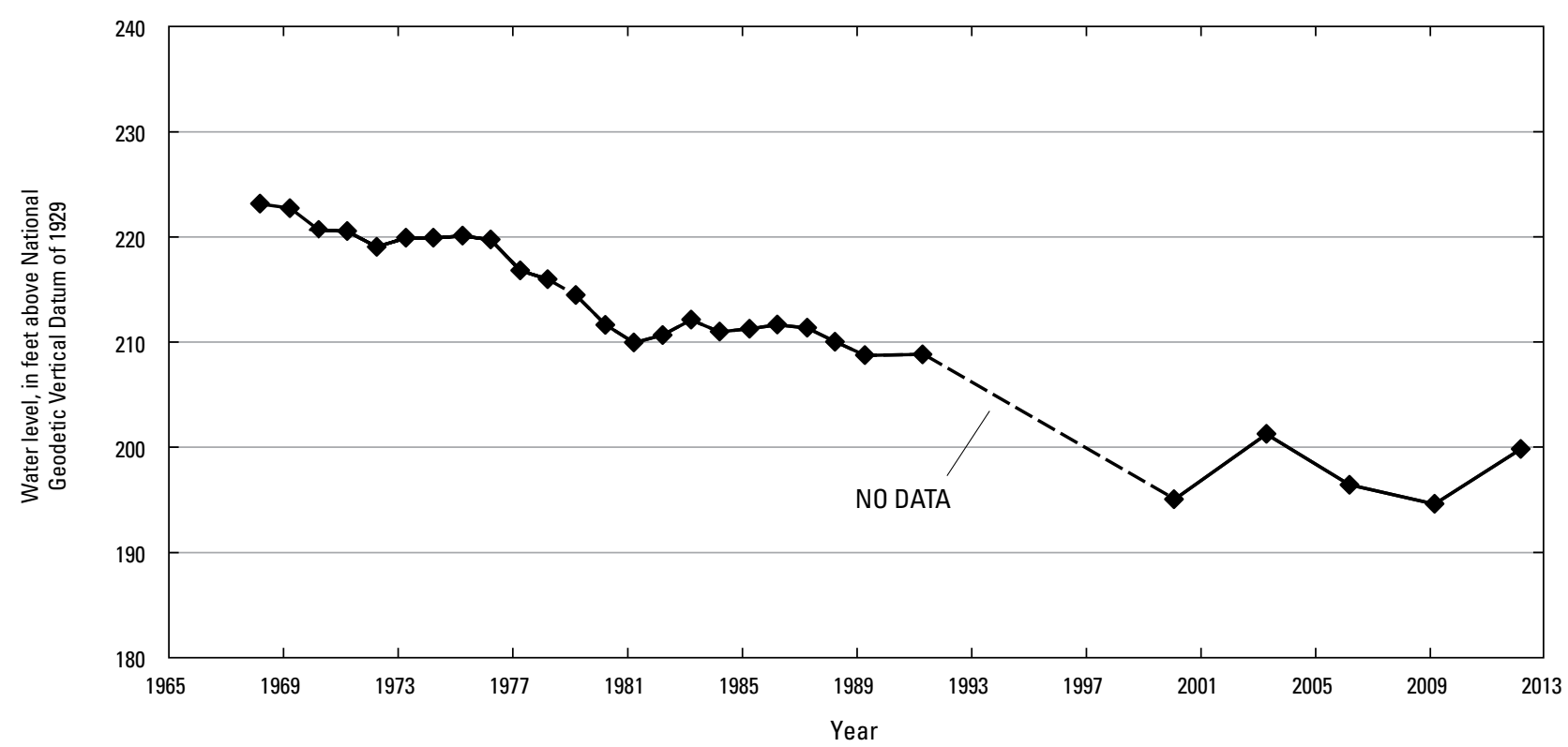

\section{N. CRITTENDEN COUNTY 08N06E33CBD1}

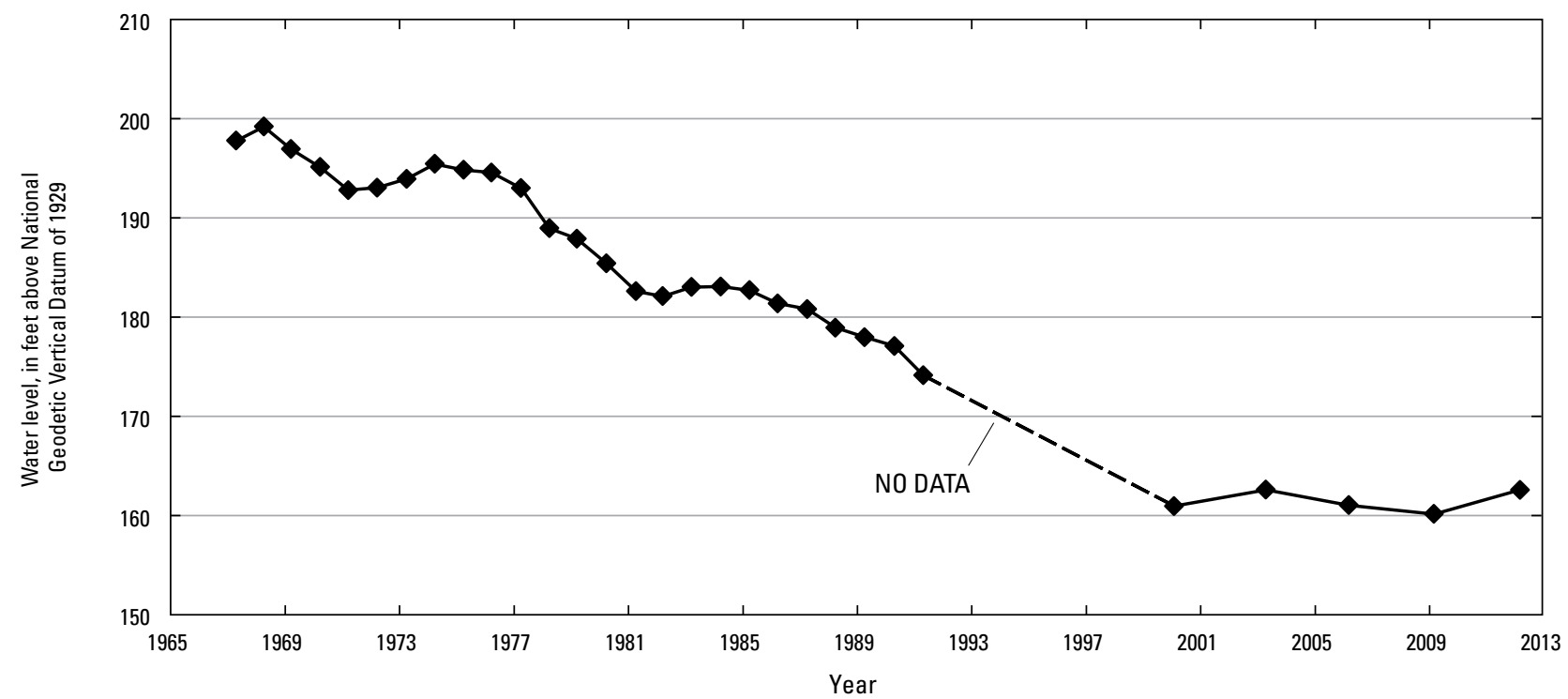

Figure 13. Water-level hydrographs for selected wells completed in the Wilcox aquifer in northeastern Arkansas. 


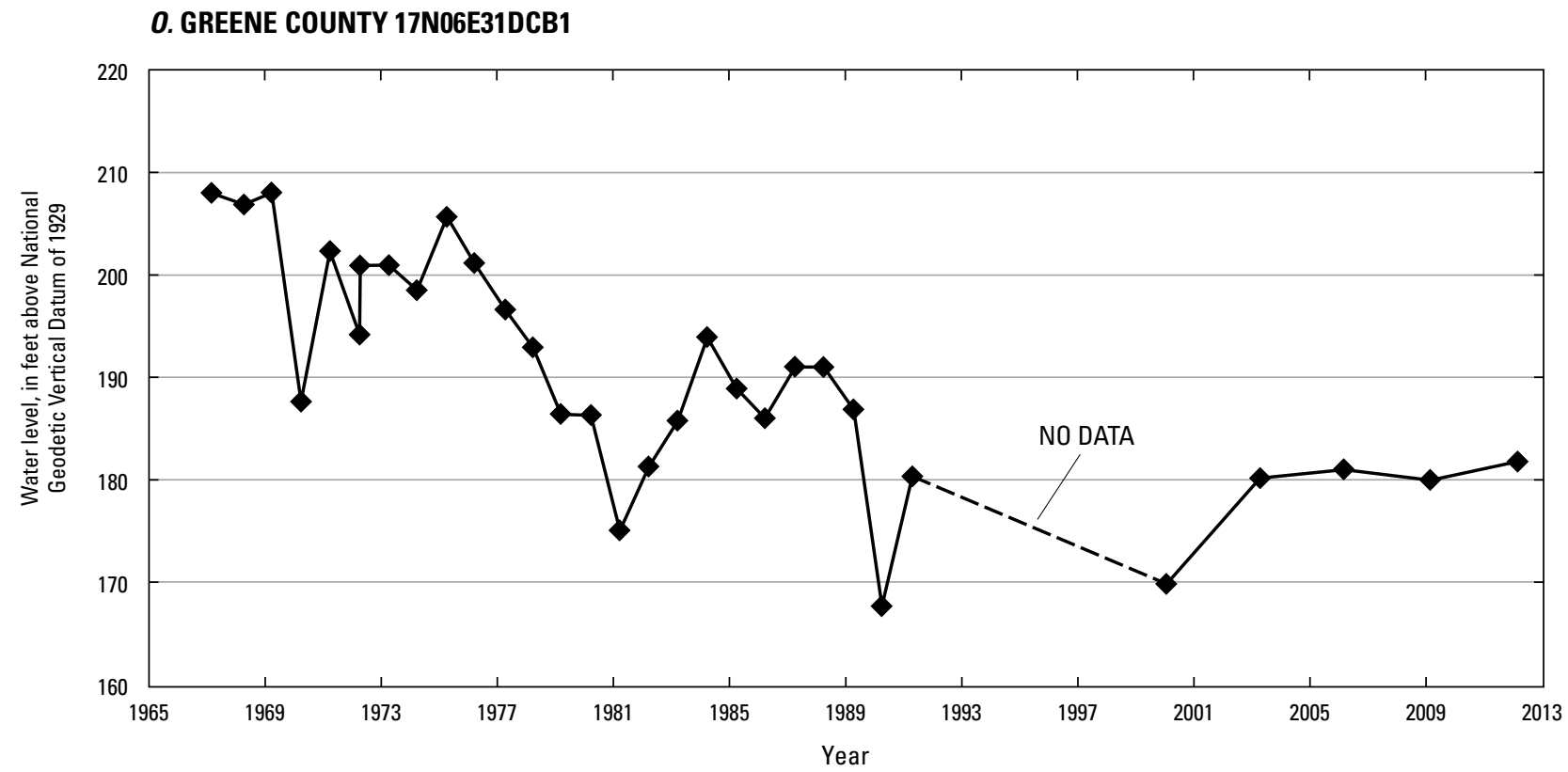

$P$. LEE COUNTY 01N04E09DCC1

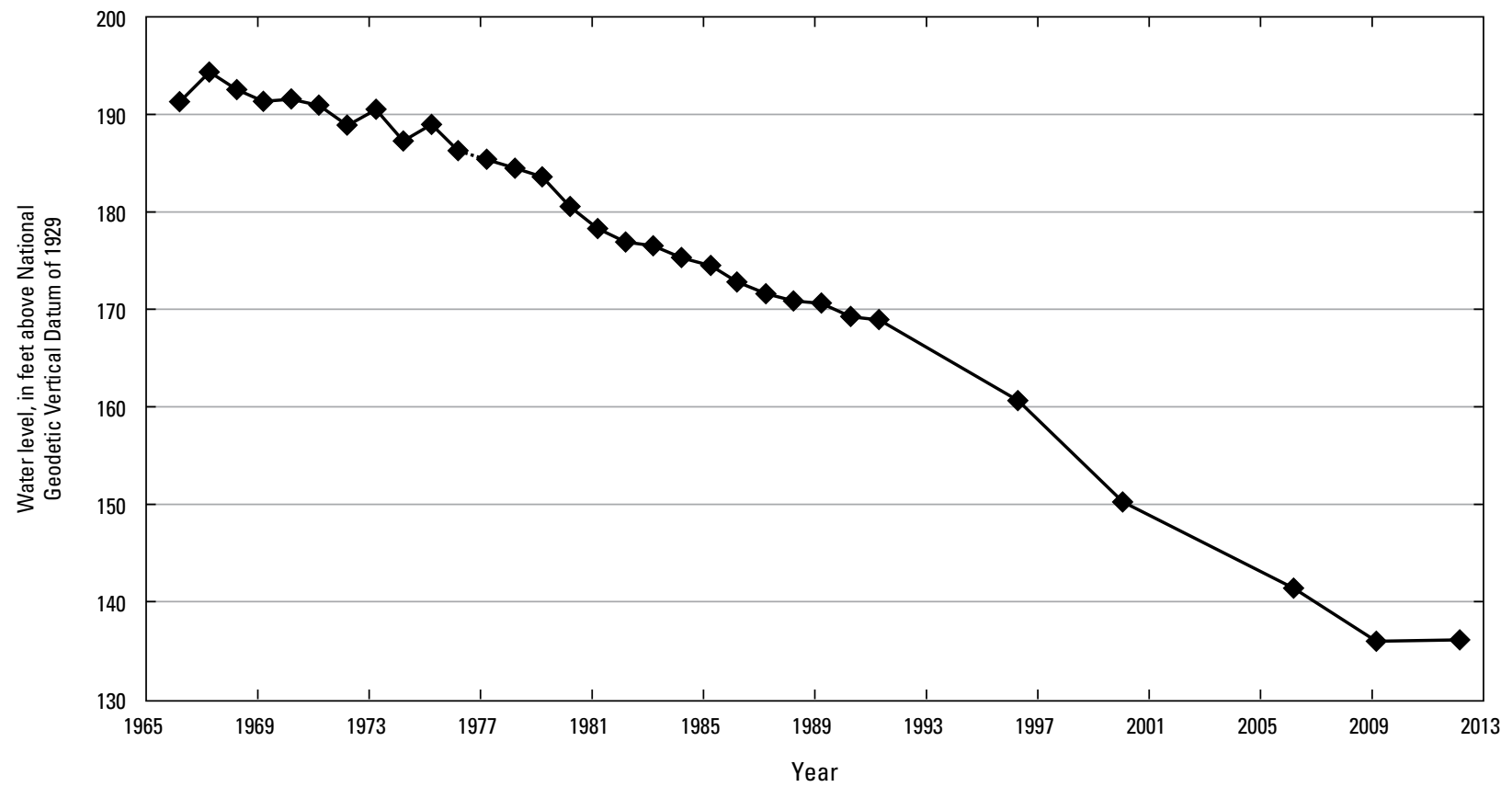

Figure 13. Water-level hydrographs for selected wells completed in the Wilcox aquifer in northeastern Arkansas. - Continued 

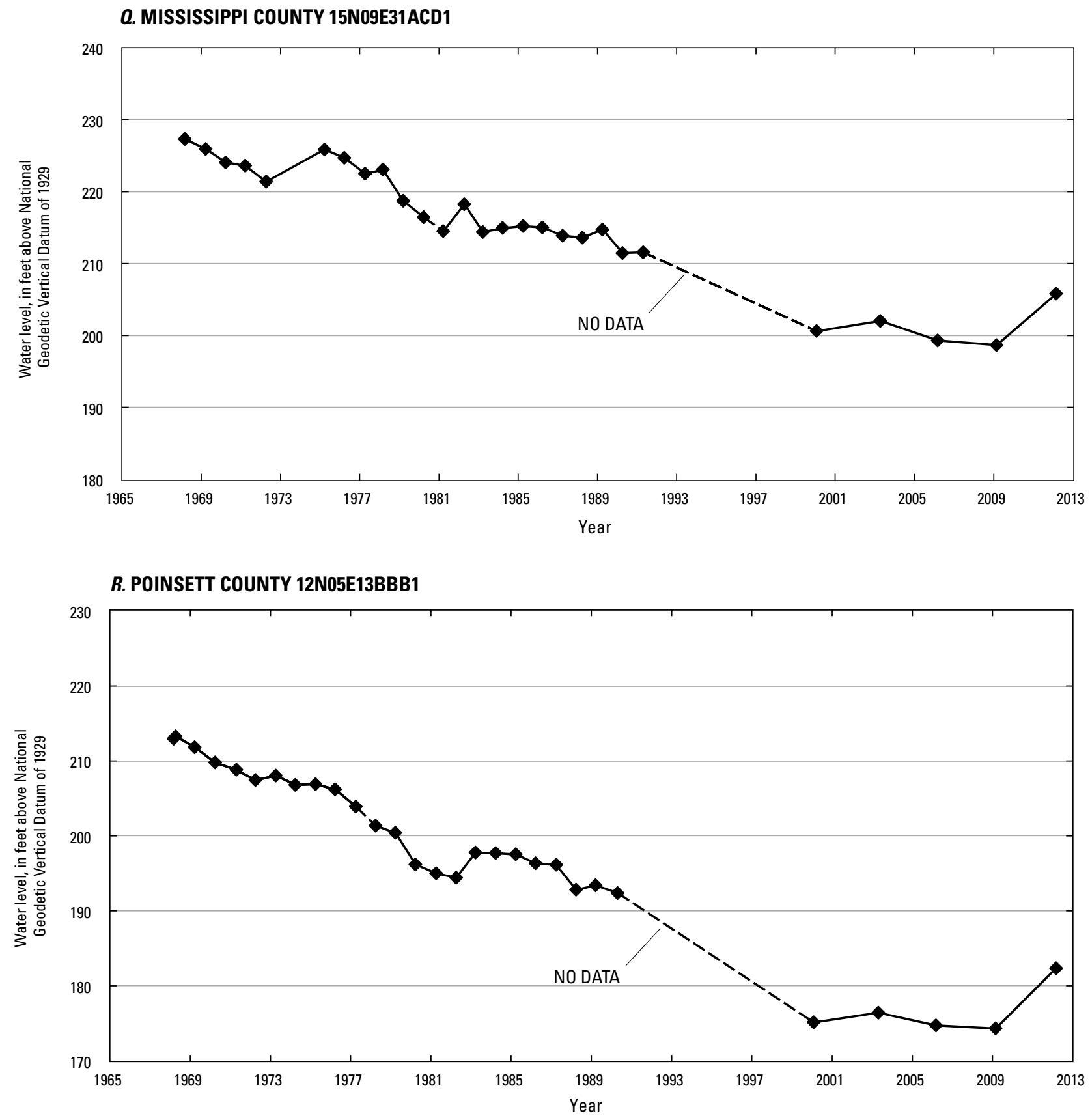

Figure 13. Water-level hydrographs for selected wells completed in the Wilcox aquifer in northeastern Arkansas.-Continued 


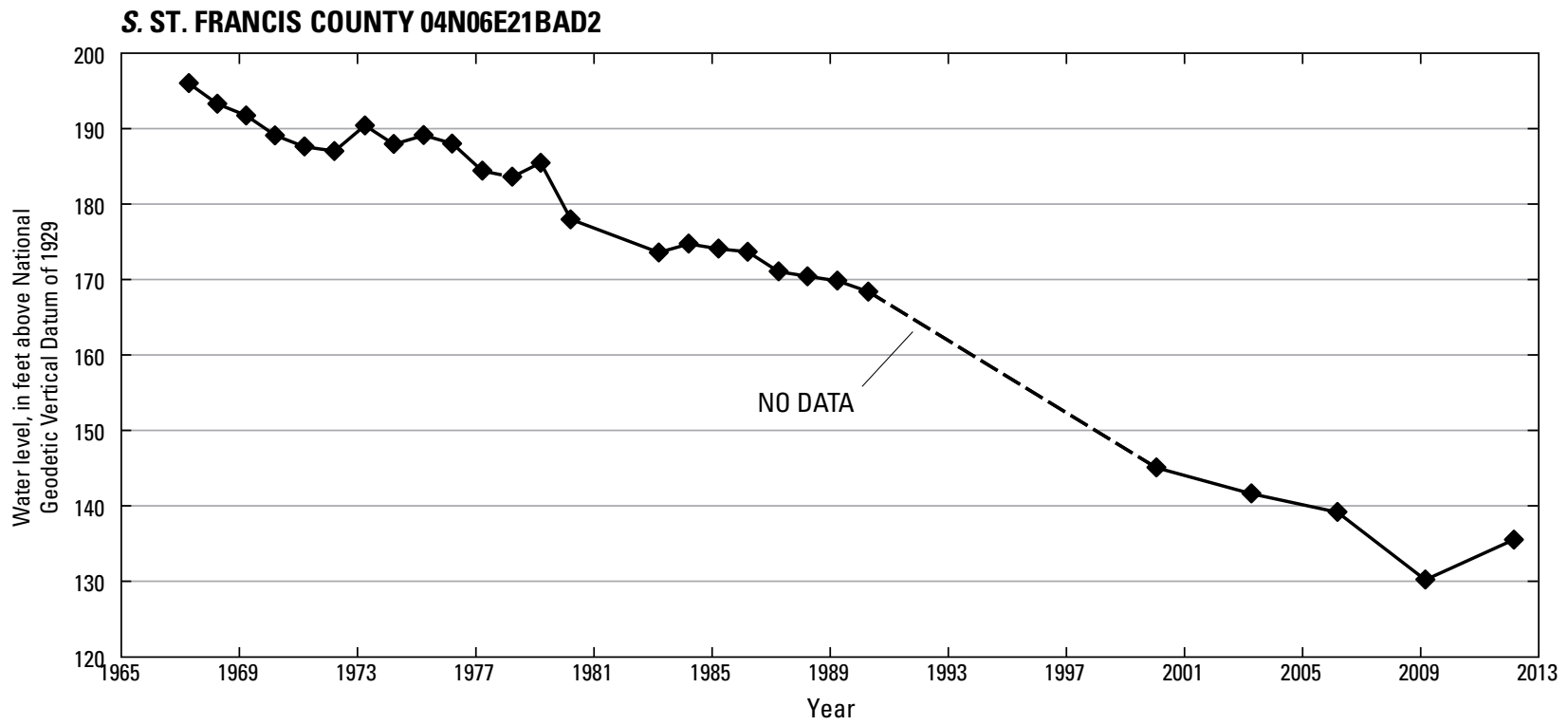

Figure 13. Water-level hydrographs for selected wells completed in the Wilcox aquifer in northeastern Arkansas.-Continued 


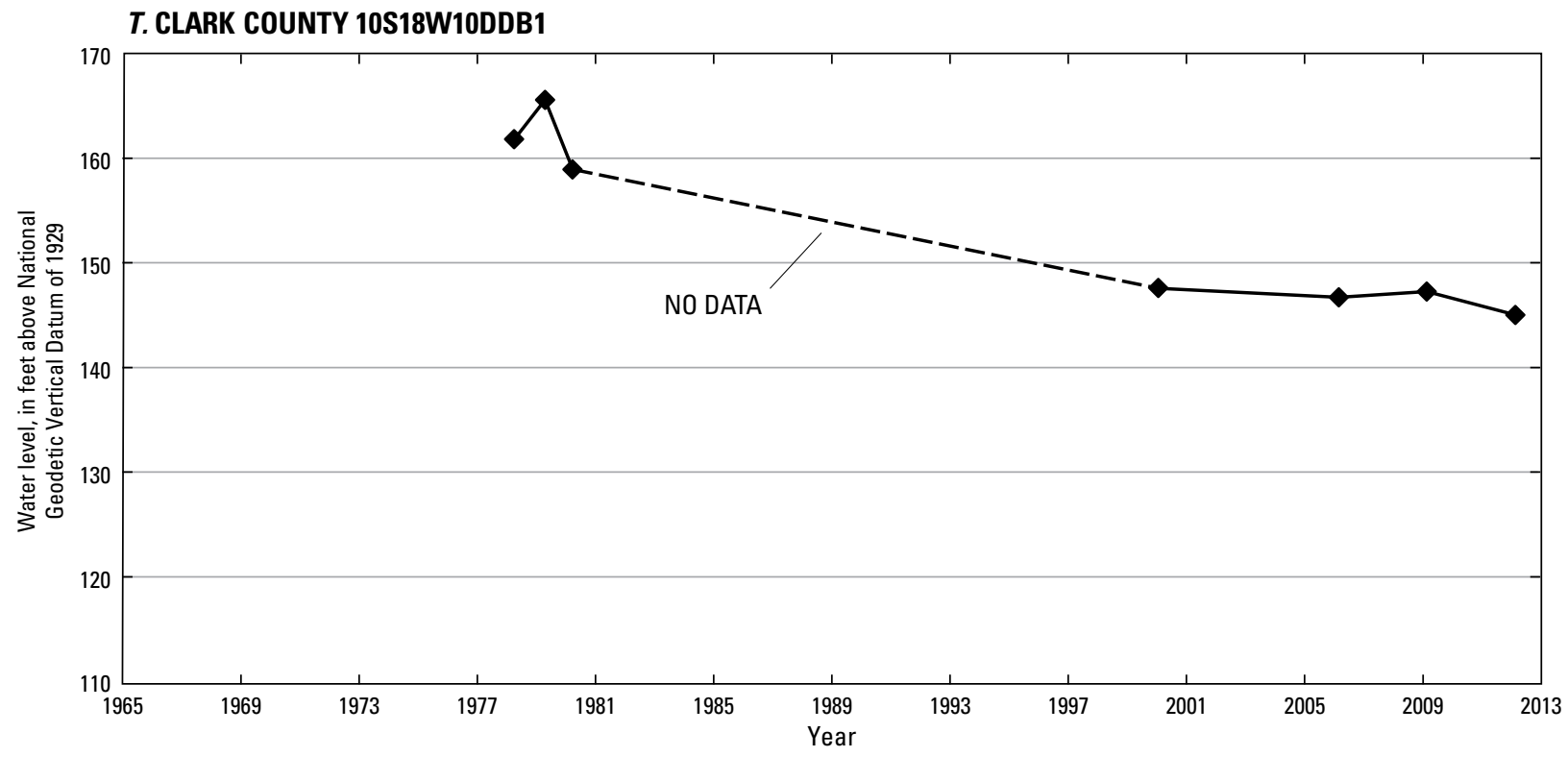

\section{U. CLARK COUNTY 09S18W20CBB1}

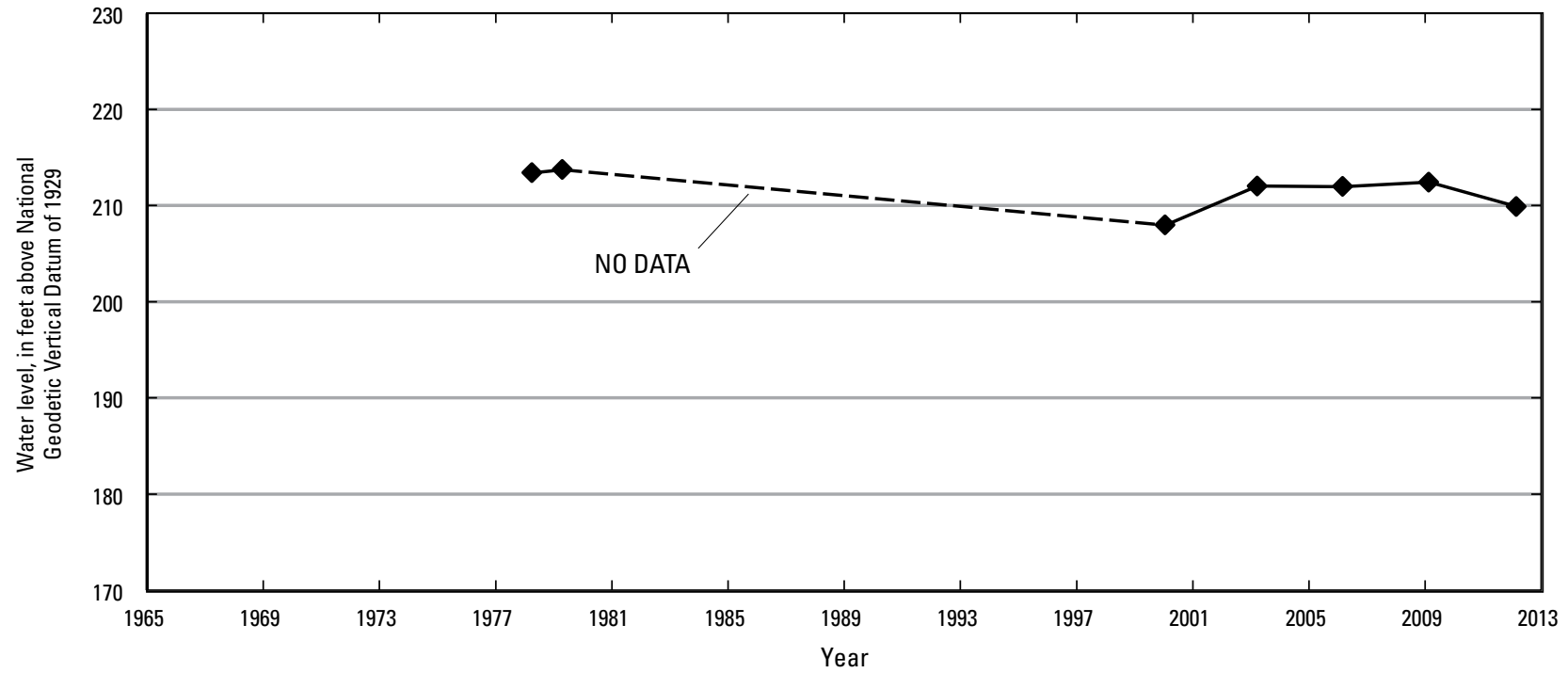

Figure 14. Water-level hydrographs for selected wells completed in the Wilcox aquifer in southern Arkansas. 


\section{HOT SPRING 04S16W20CBB1}

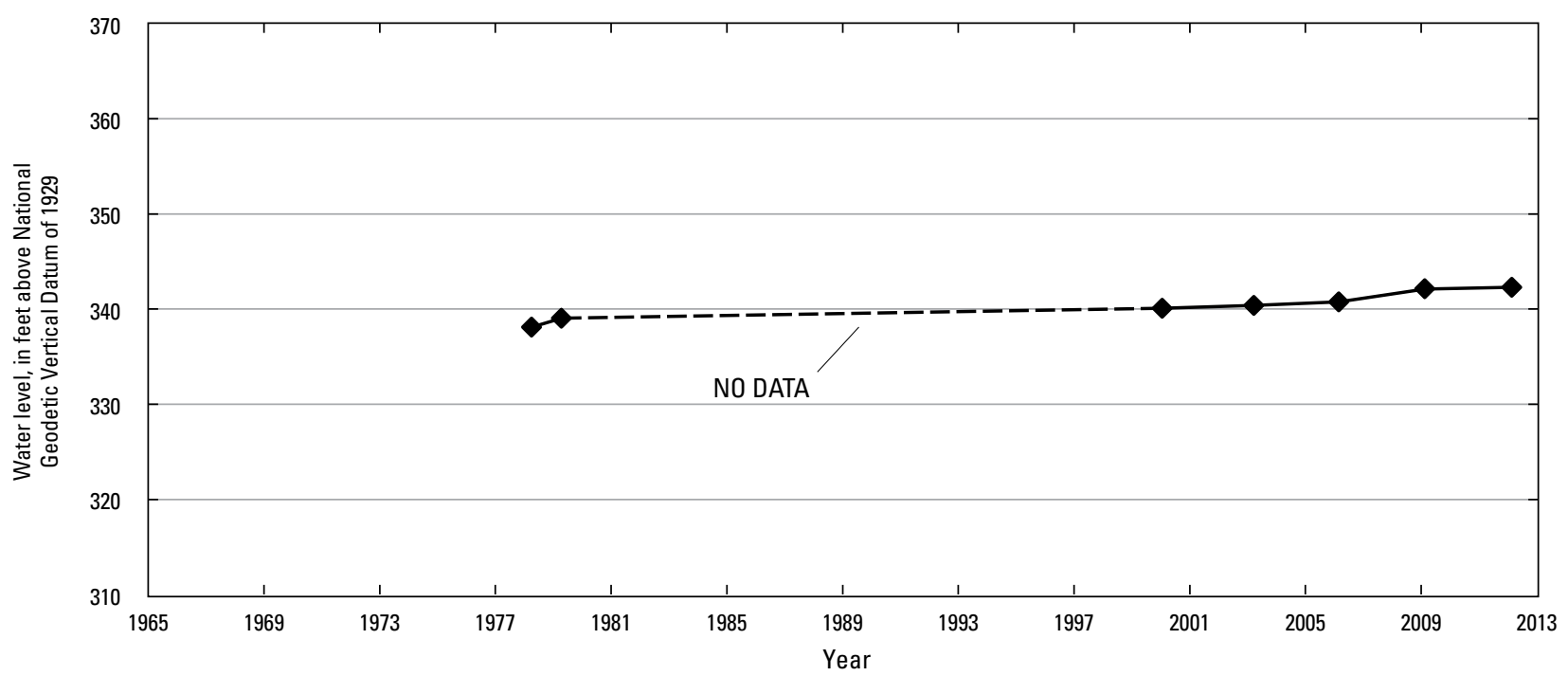

W. HEMPSTEAD COUNTY 14S24W29BCA1

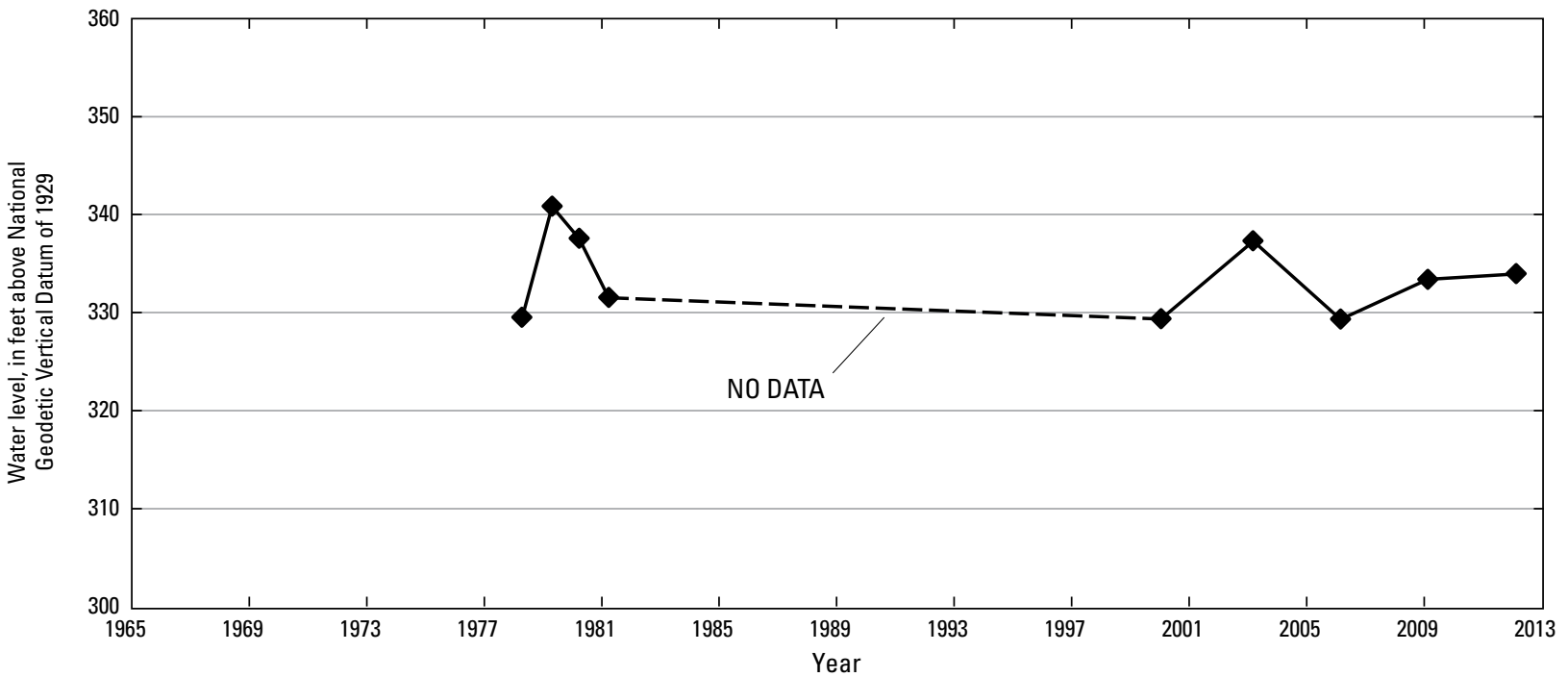

Figure 14. Water-level hydrographs for selected wells completed in the Wilcox aquifer in southern Arkansas.-Continued 


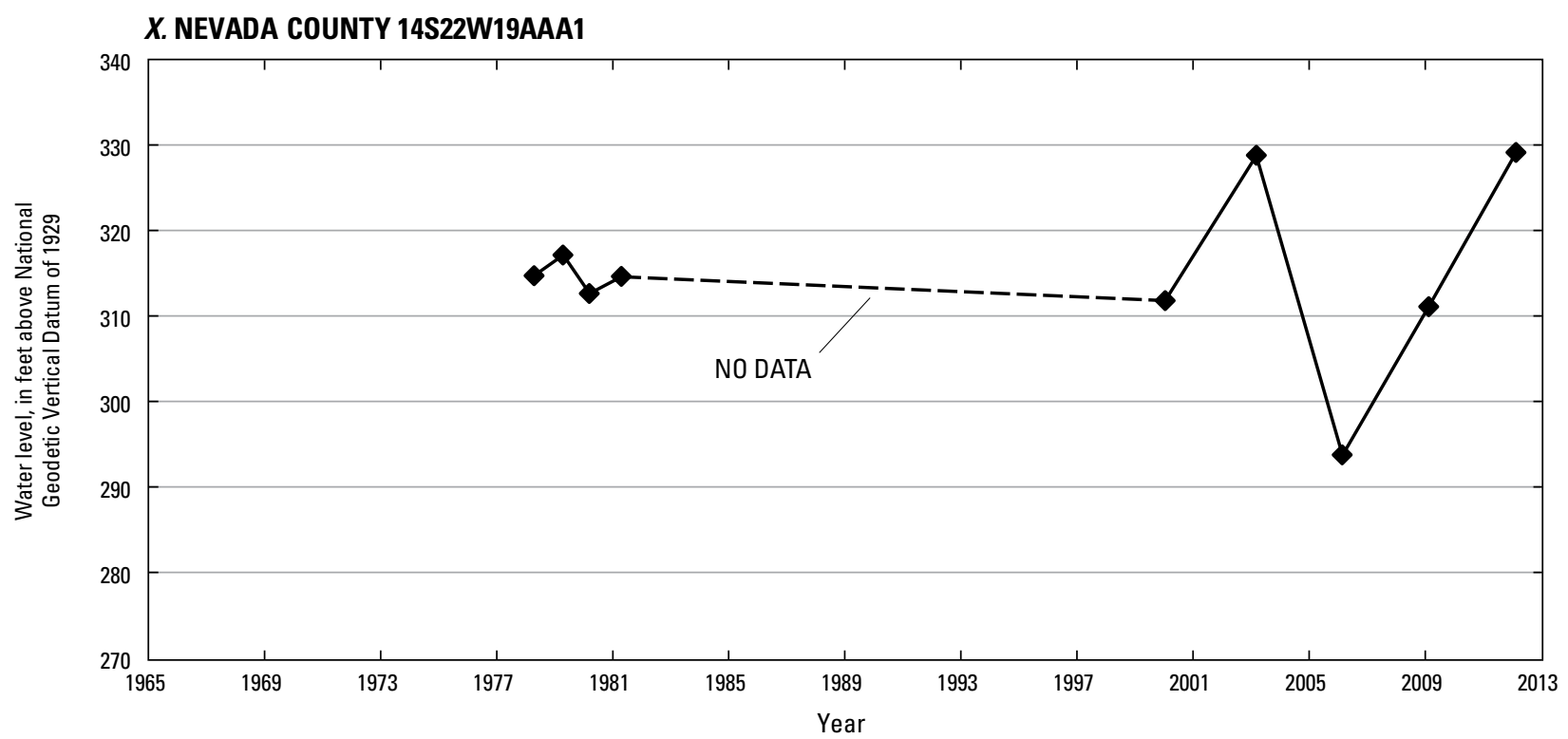

Figure 14. Water-level hydrographs for selected wells completed in the Wilcox aquifer in southern Arkansas.-Continued

Table 3. Range, mean, and median of annual rise or decline in water level by county for wells with 20 or more years of record completed in the Wilcox aquifer in Arkansas.

[Annual rise or decline in water level for each well is calculated using linear regression; negative value indicates decline; positive value indicates rise; $\mathrm{R}^{2}$, coefficient of determination]

\begin{tabular}{|c|c|c|c|c|c|}
\hline County & $\begin{array}{l}\text { Number of } \\
\text { wells }\end{array}$ & $\begin{array}{c}\text { Range of values of } \\
\text { annual rise (+) } \\
\text { or decline (-) in } \\
\text { water level } \\
\text { (feet/year) }\end{array}$ & $\begin{array}{c}\text { Mean annual rise }(+) \\
\text { or decline }(-) \text { in } \\
\text { water level } \\
\text { (feet/year) }\end{array}$ & $\begin{array}{c}\text { Median annual rise (+) } \\
\text { or decline }(-) \text { in } \\
\text { water level } \\
\text { (feet/year) }\end{array}$ & $\begin{array}{l}\text { Range of } R^{2} \text { values } \\
\text { for trend lines }\end{array}$ \\
\hline \multicolumn{6}{|c|}{ Northeastern area } \\
\hline Craighead & 4 & -0.66 to -0.43 & -0.55 & -0.55 & 0.67 to 0.92 \\
\hline Greene & 1 & -0.66 & -0.66 & -0.66 & 0.54 \\
\hline Lee & 1 & -1.31 & -1.31 & -1.31 & 0.97 \\
\hline Mississippi & 6 & -0.95 to -0.55 & -0.73 & -0.68 & 0.70 to 0.91 \\
\hline Poinsett & 3 & -0.91 to -0.80 & -0.85 & -0.84 & 0.76 to 0.93 \\
\hline Hempstead & 3 & -0.62 to -0.07 & -0.26 & -0.07 & 0.05 to 0.67 \\
\hline Hot Spring & 2 & -0.01 to 0.11 & 0.05 & 0.05 & 0.01 to 0.88 \\
\hline Nevada & 4 & -0.11 to 0.03 & -0.03 & -0.04 & 0.00 to 0.16 \\
\hline
\end{tabular}




\section{Summary}

The Cockfield aquifer located in southern Arkansas is composed of Eocene-age sand beds found near the base of the Cockfield Formation of Claiborne Group. The Wilcox aquifer located in northeastern and southern Arkansas, is composed of Paleocene-age sand beds found in the middle to lower part of the Wilcox Group. The Cockfield and Wilcox aquifers are primary sources of groundwater. In 2010, withdrawals from the Cockfield aquifer in Arkansas totaled 19.2 (Mgal/d) and withdrawals from the Wilcox aquifer totaled $36.5 \mathrm{Mgal} / \mathrm{d}$.

Water levels were measured at 43 wells completed in the Cockfield aquifer and 47 wells completed in the Wilcox aquifer in February and March 2012. Measurements from 2012 are presented as potentiometric-surface maps and in combination with measurements from 2006 as water-level difference maps. Trends in water-level change over time within the Cockfield and Wilcox aquifers were determined using the water-level difference maps and selected well hydrographs. Hydrogaphs for selected wells were constructed using 20 or more years of historical water-level data.

The Cockfield aquifer study area in southern Arkansas is bounded on the east by the Mississippi River and on the west by the area that contains outcrops and subcrops of the Cockfield Formation. The northern boundary of the Cockfield aquifer study area is defined by the area that contains observation wells completed in the Cockfield aquifer and the southern boundary is the Louisiana State line. The Wilcox aquifer study area in northeastern Arkansas is bounded on the east by the Mississippi River and on the north by the Missouri State line. The southern and western boundaries are defined by areas containing observation wells completed in the Wilcox aquifer or by outcrop areas on or near Crowleys Ridge. The Wilcox aquifer study area in southern Arkansas is defined by observation wells completed in the Wilcox aquifer or by areas that contain outcrops of the Wilcox Group, or both.

The potentiometric surface of the Cockfield aquifer shows the regional direction of groundwater flow was generally toward the east-southeast, except in areas of intense groundwater withdrawals such as southwestern Ashley County, where groundwater flows toward the town of Crossett. In southern Columbia County, a trough in the potentiometic surface exists, which locally alters the flow of groundwater. The highest water-level altitude measured was 350 feet (ft) above National Geodetic Vertical Datum of 1929 (NGVD 29) in central Columbia County. The lowest water-level altitude measured was $40 \mathrm{ft}$ above NGVD 29 in southeastern Lincoln County.

The 2006 to 2012 difference in water levels for the Cockfield aquifer ranged from 27.4 to $-10.4 \mathrm{ft}$. The largest water-level rise was in Calhoun County, and the largest waterlevel decline was in Union County. Of the 42 wells, 13 wells had a rise in water levels, and the remaining 29 wells had a decline in water levels from 2006 to 2012.

Analysis of selected hydrographs was divided into three geographic regions: the area east of the Saline River
(Ashley, Chicot, Desha, Drew, Lincoln, and part of Cleveland Counties), the area between the Saline and Ouachita Rivers (Bradley, Calhoun, and part of Cleveland Counties), and the area west of the Ouachita River (Columbia and Union Counties). Hydrographs for wells located east of the Saline River and screened within the confined part of the Cockfield aquifer indicated changes in water levels that range from a rise of approximately $0.5 \mathrm{ft}$ to a decline of approximately $57 \mathrm{ft}$ over the period of record.

Hydrographs for wells located in the area between the Saline and Ouachita Rivers were screened in confined and unconfined areas of the Cockfield aquifer. The hydrographs indicate rises and declines in water levels that ranged from a rise of approximately $1 \mathrm{ft}$ to a decline of approximately $23 \mathrm{ft}$ over the period of record. Hydrographs for wells located in the area west of the Ouachita River indicated rises and declines in water levels that ranged from a rise of approximately $2 \mathrm{ft}$ to a decline of approximately $5 \mathrm{ft}$ over the period of record.

Hydrographs for the 32 wells with historical water-level data in the Cockfield aquifer were evaluated using linear regression to calculate the annual rise or decline for each well and the data were aggregated by county and statistically evaluated for the range, mean, and median of water-level change in each county. Bradley, Calhoun, Columbia, and Union Counties indicate rising and declining water levels. The mean annual water-level rise or decline for Calhoun County was $0.00 \mathrm{ft} / \mathrm{yr}$ or unchanged. The mean annual waterlevel data for Ashley, Bradley, Chicot, Cleveland, Columbia, Lincoln, and Union Counties show declines ranging from -0.02 to $-1.10 \mathrm{ft} / \mathrm{yr}$.

Two potentiometric-surface maps, one for the northeastern area and one for the southern area, were constructed to show the altitude of the water surface in the Wilcox aquifer. The maps were constructed using water-level data collected in February and March 2012 from 47 wells; 31 wells in the northeastern area and 16 wells in the southern area. The direction of groundwater flow in the northeastern area was generally towards the south-southwest except for some areas immediately adjacent to the Mississippi River where the flow was more eastward towards the river. The highest water-level altitude was $219 \mathrm{ft}$ in northern Mississippi County, and the lowest water-level altitude was $123 \mathrm{ft}$ near West Memphis in Crittenden County. In Greene County, a water-level altitude of $182 \mathrm{ft}$ was measured near Crowleys Ridge. Within Crowleys Ridge, water levels in the Wilcox aquifer were perched at higher water-level altitudes than the aquifer in the surrounding Mississippi Alluvial Plain. The direction of groundwater flow in the southern area was generally towards the southwest in the northern part. The direction of groundwater flow in the southern part was in all directions because of two cones of depression and two water-level mounds. The water-level mounds are the result of the higher land-surface altitudes in the outcrop area. The highest water-level altitude measured was $394 \mathrm{ft}$ at the center of the water-level mounds in eastern Hot Spring County 
and southwestern Hempstead County. The lowest water-level altitude measured was $145 \mathrm{ft}$ at the center of the cone of depression in Clark County.

Water-level difference maps for the Wilcox aquifer in Arkansas were constructed using 47 water-level measurements made during 2006 and 2012. Difference values were obtained from water levels measured in 31 wells in the northeastern area of the Wilcox aquifer and 16 wells measured in the southern area. The difference in water levels for the Wilcox aquifer in the northeastern area ranged from $22.0 \mathrm{ft}$ to $-17.9 \mathrm{ft}$. The largest rise in water levels occurred in Crittenden County, and the largest decline was in Lee County. Twenty-one wells had rising water levels, and 10 wells had declining water levels. The difference in water levels for the Wilcox aquifer in the southern area ranged from $18.1 \mathrm{ft}$ to $-4.2 \mathrm{ft}$. The largest rise and the largest decline in water levels occurred in Nevada County. Twelve wells had rising water levels, and 4 wells had declining water levels.

Hydrographs for the northeastern area showed declining water levels. Water-level changes in selected wells ranged from a decline of approximately $23 \mathrm{ft}$ to a decline of approximately $60 \mathrm{ft}$. Hydrographs in the southern area showed declining and rising water levels. Water-level changes in selected wells ranged from a rise of approximately $14 \mathrm{ft}$ to a decline of approximately $20 \mathrm{ft}$.

Linear regression analysis of long-term hydrographs was used to determine the mean annual water-level rise and decline in the Wilcox aquifer in the northeastern area and southern area of Arkansas. In the northeastern area, the mean annual water level declined in all seven counties. The mean annual declines ranged from $-0.55 \mathrm{ft} / \mathrm{yr}$ in Craighead County to -1.46 $\mathrm{ft} / \mathrm{yr}$ in St. Francis County.

In the southern area, the annual rise or decline calculations for wells with over 20 years of record indicated rising and declining water levels in Clark, Hot Spring, and Nevada Counties. The mean annual water level declined in all counties except Hot Spring County.

This is the sixth in a series of triennial reports discussing the potentiometric surfaces of the Cockfield and Wilcox aquifers. This report and the previous five reports were prepared in cooperation with the Arkansas Natural Resources Commission and the Arkansas Geological Survey.

\section{References Cited}

Ackerman, D.J., 1987, Generalized potentiometric surface of the aquifers in the Cockfield Formation, southeastern Arkansas, spring 1980: U.S. Geological Survey WaterResources Investigations Report 87-4214, scale 1:500,000, 1 sheet.

Albin, D.R., 1964, Geology and ground-water resources of Bradley, Clahoun, and Ouachita Counties, Arkansas: U.S. Geological Survey Water-Supply Paper 1779-G, 32 p.
Arthur, J.K., and Taylor, R.E., 1990, Definition of the geohydrologic framework and preliminary simulation on ground-water flow in the Mississippi Embayment aquifer system, Gulf Coastal Plain, United States: U.S. Geological Survey Water-Resources Investigations Report 86-4364, $97 \mathrm{p}$.

Bodansky, Eugene, Gribov, Alexander, and Pilouk, Morakot, 2002, Smoothing and compression of lines obtained by raster-to-vector conversion: Lecture Notes in Computer Science Volume 2390, Springer Publishing Co., p. 256-265.

Broom, M.E., and Lyford, F.P., 1981, Alluvial aquifer of the Cache and St. Francis River Basins, northeastern Arkansas: U.S. Geological Survey Open-File Report 81-476, 48 p.

Esri, 2011, ArcGIS desktop - Release 10: Redlands, California, Environmental Systems Research Institute.

Fenneman, N.M., and Johnson, D.W., 1946, Physical divisions of the United States (map): Washington, D.C., U.S. Geological Survey.

Halberg, H.N., and Johnson, D.W., 1977, Use of water in Arkansas, 1975: Arkansas Geological Commission Water Resources Summary Number 9, 28 p.

Hart, R.M., Clark, B.R., and Bolyard, S.E., 2008, Digital surfaces and thicknesses of selected hydrogeologic units within the Mississippi Embayment Regional Aquifer Study (MERAS): U.S. Geological Survey Scientific Investigations Report 2008-5098, 33 p.

Helsel, D.R., and Hirsh, R.M., 1992, Statistical methods in water resources: New York, N.Y., Elsevier Science Publishing Co., $522 \mathrm{p}$.

Holland, T.W., 1987, Use of water in Arkansas, 1985: Arkansas Geological Commission Water Resources Summary Number 6, $30 \mathrm{p}$.

Holland, T.W., 1993, Use of Water in Arkansas, 1990: U.S. Geological Survey Open-File Report 93-48, pamphlet.

Holland, T.W., 1999, Water use in Arkansas, 1995: U.G. Geological Survey Open-File Report 99-188, 1 sheet.

Holland, T.W., 2004, Estimated water use in Arkansas, 2000: U.S. Geological Survey Scientific Investigations Report 2004-5230, $31 \mathrm{p}$.

Holland, T.W., 2007, Water use in Arkansas, 2005: U.S. Geological Survey Scientific Investigations Report 2007$5241,32 \mathrm{p}$.

Holland, T.W., and Ludwig, A. H., 1981, Use of water in Arkansas, 1980: Arkansas Geological Commission Water Resources Summary Number 14, 30 p.

Hosman, R.L., 1982, Outcropping Tertiary units in southern Arkansas: U.S. Geological Survey Miscellaneous Investigations Series I-1405, 1 sheet. 
Hosman, R.L., 1988, Geohydrologic framework, Gulf Coastal Plain: U.S. Geological Survey Hydrologic Investigations Atlas HA-695, 2 sheets.

Hosman, R.L., Long, A.T., Lambert, T.W., and others, 1968, Tertiary aquifers in the Mississippi Embayment: U.S. Geological Survey Professional Paper 448-D, 29 p.

Hosman, R.L., and Weiss, J.S., 1991, Geohydrologic units of the Mississippi Embayment and Texas Coastal Uplands aquifer systems, South-Central United States: U.S. Geological Survey Professional Paper 1416-B, 19 p.

Joseph, R.L., 1998, Potentiometric surface of the Cockfield aquifer in southeastern Arkansas and the Wilcox aquifers in southern and northeastern Arkansas, October 1996July 1997: U.S. Geological Survey Water-Resources Investigations Report 98-4084, 19 p.

Onellion, F.E., and Criner, J.H., Jr., 1955, Ground-water resources of Chicot County, Arkansas: Arkansas Geological and Conservation Commission Water Resources Circular No. 3, 27 p.

Petersen, J.C., Broom, M.E., and Bush, W.V., 1985, Geohydrologic units of the Gulf Coastal Plain in Arkansas: U.S. geological Survey Water-Resources Investigations Report 85-4116, 20 p.

Plebuch, R.O., 1961, Fresh-water aquifers of Crittenden County, Arkansas: Arkansas Geological and Conservation Commission Water Resources Circular 8, 65 p.

Pugh, A.L., 2008, Summary of aquifer test data for Arkansas-1940-2006: U.S. Geological Survey Scientific Investigations Report 2008-5149, 33 p.
Pugh, A.L., 2010, Potentiometric surfaces and water-level trends in the Cockfield (upper Claiborne) and Wilcox (lower Wilcox) aquifers of southern and northeastern Arkansas, 2009: U.S. Geological Survey Scientific Investigations Report 2010-5014, 47 p.

Ryling, R.W., 1960, Ground-water potential of Mississippi County, Arkansas: Arkansas Geological and Conservation Commission Water Resources Circular 7, 87 p.

Schrader, T.P., 2007, Potentiometric surfaces and water-level tends in the Cockfield and Wilcox aquifers of southern and northeastern Arkansas, 2006: U.S. Geological Survey Scientific Investigations Report 2007-5218, 27 p.

Schrader, T.P., and Joseph, R.L., 2000, Potentiometric surfaces of aquifers in the Cockfield Formation in southeastern Arkansas and the Wilcox Group in southern and northeastern Arkansas, 2000: U.S. Geological Survey Water-Resources Investigations Report 00-4206, 22 p.

U.S. Geological Survey, 2002, National Water Information System: Accessed October 10, 2013, at http://waterdata. usgs.gov/nwis.

U.S. Geological Survey, 2014, National atlas of the United States: Accessed April 21, 2014 , at http://www.usgs.gov/ science/cite-view.php?cite $=244$.

Westerfield, P.W., 1994, Potentiometric-surface maps of the Cockfield and lower Wilcox aquifers in Arkansas, 1991: U.S. Geological Survey Water-Resources Investigations Report 93-4134, scale 1:500,000, 2 sheets.

Yeatts, D.S., 2004, Potentiometric Surfaces in the Cockfield and Wilcox aquifers of southern and northeastern Arkansas, 2003: U.S. Geological Survey Scientific Investigations Report 2004-5169, 24 p. 



\section{Appendixes}



Appendix 1. Water-level data collected during February 2012 from wells completed in the Cockfield aquifer in southern Arkansas.

[Horizontal datum is North America Datum of 1983; NGVD 29, National Geodetic Vertical Datum of 1929; Letters in parentheses correspond to well locations in figure 5 and well hydrographs in figure 7 ; --, missing data]

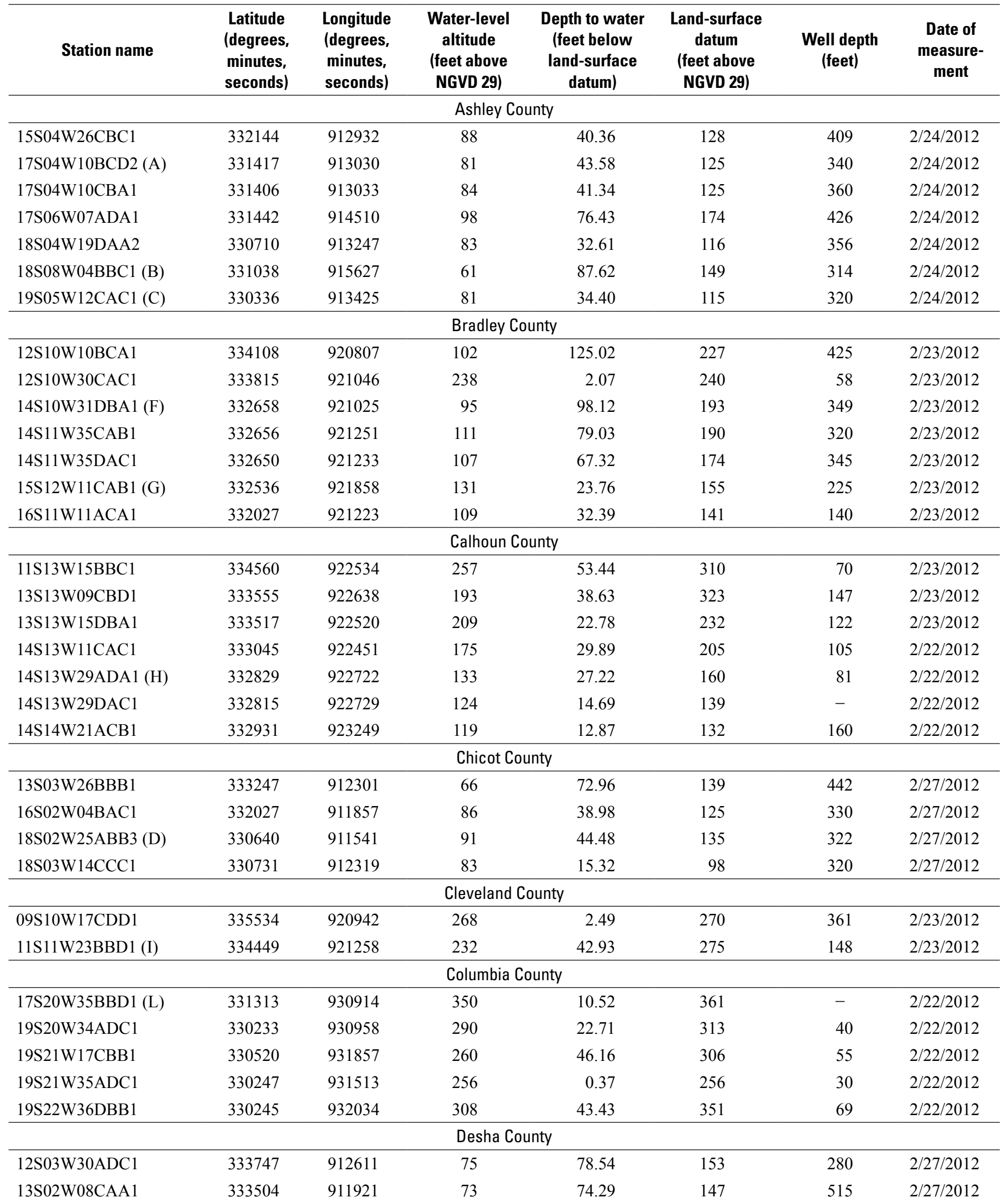


Appendix 1. Water-level data collected during February 2012 from wells completed in the Cockfield aquifer in southern Arkansas.Continued

[Horizontal datum is North America Datum of 1983; NGVD 29, National Geodetic Vertical Datum of 1929; Letters in parentheses correspond to well locations in figure 5 and well hydrographs in figure 7 ; --, missing data]

\begin{tabular}{|c|c|c|c|c|c|c|c|}
\hline Station name & $\begin{array}{c}\text { Latitude } \\
\text { (degrees, } \\
\text { minutes, } \\
\text { seconds) }\end{array}$ & $\begin{array}{l}\text { Longitude } \\
\text { (degrees, } \\
\text { minutes, } \\
\text { seconds) }\end{array}$ & $\begin{array}{c}\text { Water-level } \\
\text { altitude } \\
\text { (feet above } \\
\text { NGVD 29) }\end{array}$ & $\begin{array}{l}\text { Depth to water } \\
\text { (feet below } \\
\text { land-surface } \\
\text { datum) }\end{array}$ & $\begin{array}{c}\text { Land-surface } \\
\text { datum } \\
\text { (feet above } \\
\text { NGVD 29) }\end{array}$ & $\begin{array}{l}\text { Well depth } \\
\text { (feet) }\end{array}$ & $\begin{array}{c}\text { Date of } \\
\text { measure- } \\
\text { ment }\end{array}$ \\
\hline 14S06W21BDC1 & 332846 & 914339 & 99 & 117.19 & 216 & - & $2 / 24 / 2012$ \\
\hline 11S05W35DDB1 & 334216 & 913438 & 60 & 119.60 & 180 & 500 & $2 / 27 / 2012$ \\
\hline \multicolumn{8}{|c|}{ Lincoln County } \\
\hline 10S05W06CAC1 (E) & 335204 & 913918 & 40 & 130.29 & 170 & 550 & $2 / 27 / 2012$ \\
\hline \multicolumn{8}{|c|}{ Union County } \\
\hline 16S18W22DCD1 & 331913 & 925704 & 222 & 25.15 & 247 & 36 & $2 / 22 / 2012$ \\
\hline 17S13W17DDC1 (J) & 331402 & 922746 & 153 & 40.52 & 193 & 24 & $2 / 22 / 2012$ \\
\hline 17S15W31DCA2 & 331144 & 924116 & 199 & 54.41 & 253 & 110 & $2 / 22 / 2012$ \\
\hline
\end{tabular}


Appendix 2. Difference in depth to water from 2006 to 2012 in the Cockfield aquifer in southern Arkansas.

[Horizontal datum is North American Datum of 1983; Vertical coordinate information is referenced to the National Geodetic Vertical Datum of 1929; positive differences in depth to water indicate a rise in water levels from 2006 to 2012 whereas negative values indicate a decline in water levels from 2006 to 2012]

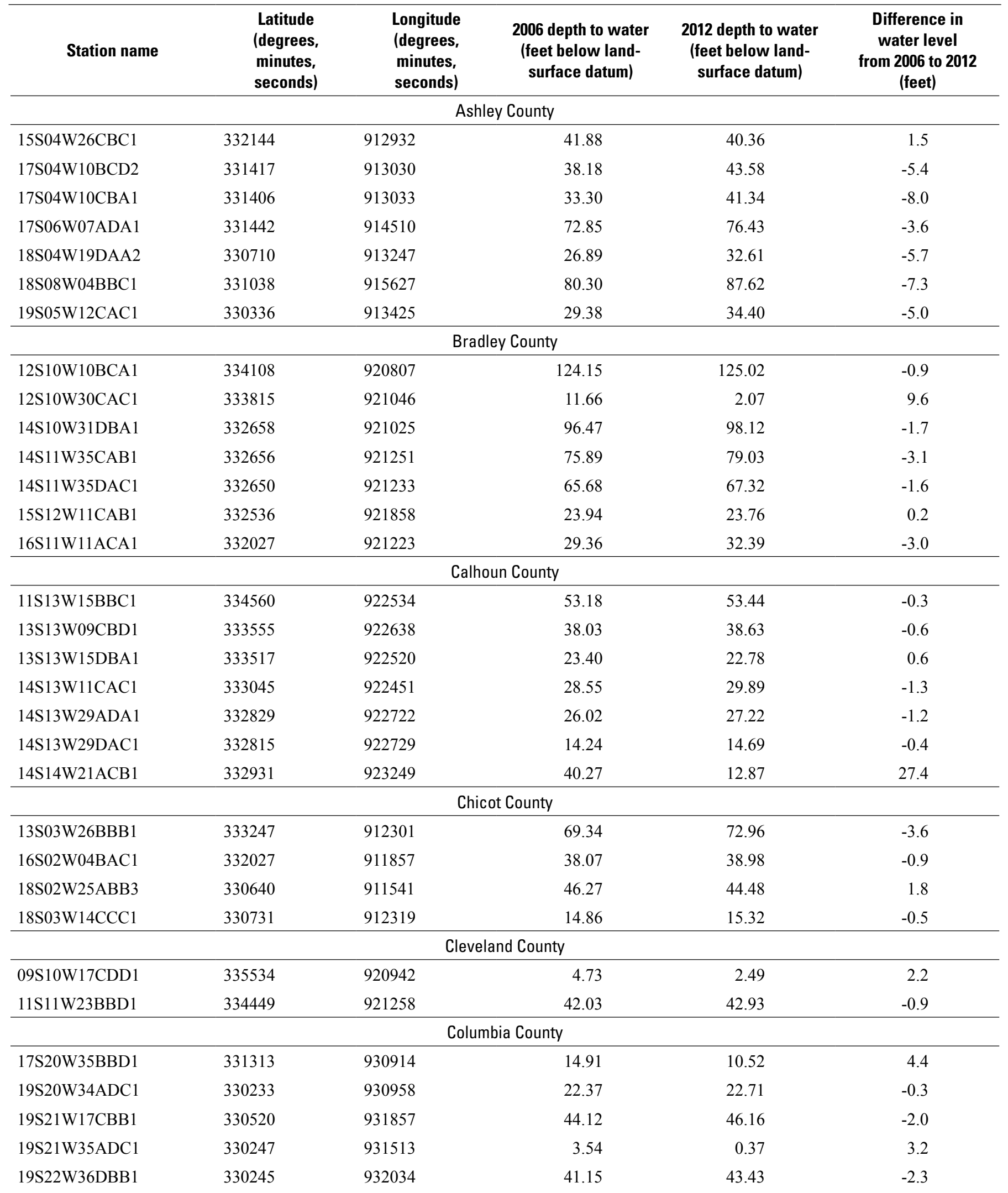


Appendix 2. Difference in depth to water from 2006 to 2012 in the Cockfield aquifer in southern Arkansas.-Continued

[Horizontal datum is North American Datum of 1983;Vertical coordinate information is referenced to the National Geodetic Vertical Datum of 1929; positive differences in depth to water indicate a rise in water levels from 2006 to 2012 whereas negative values indicate a decline in water levels from 2006 to 2012]

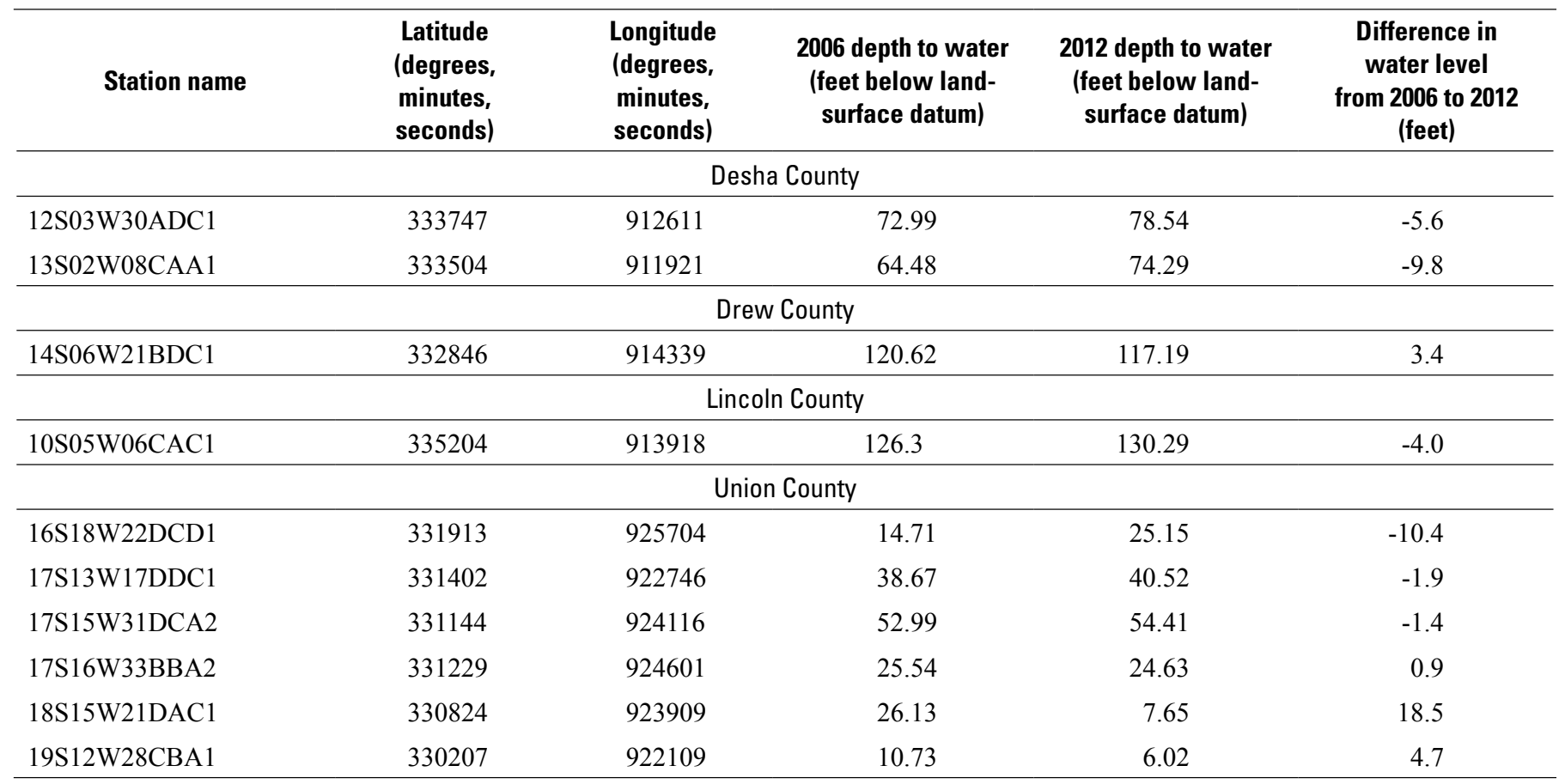


Appendix 3. Water-level data collected during February and March 2012 from wells completed in the Wilcox aquifer in northeastern Arkansas.

[Horizontal datum is North America Datum of 1983; NGVD 29, National Geodetic Vertical Datum of 1929; Letters in parentheses correspond to well locations in figure 9 and well hydrographs in figure 13]

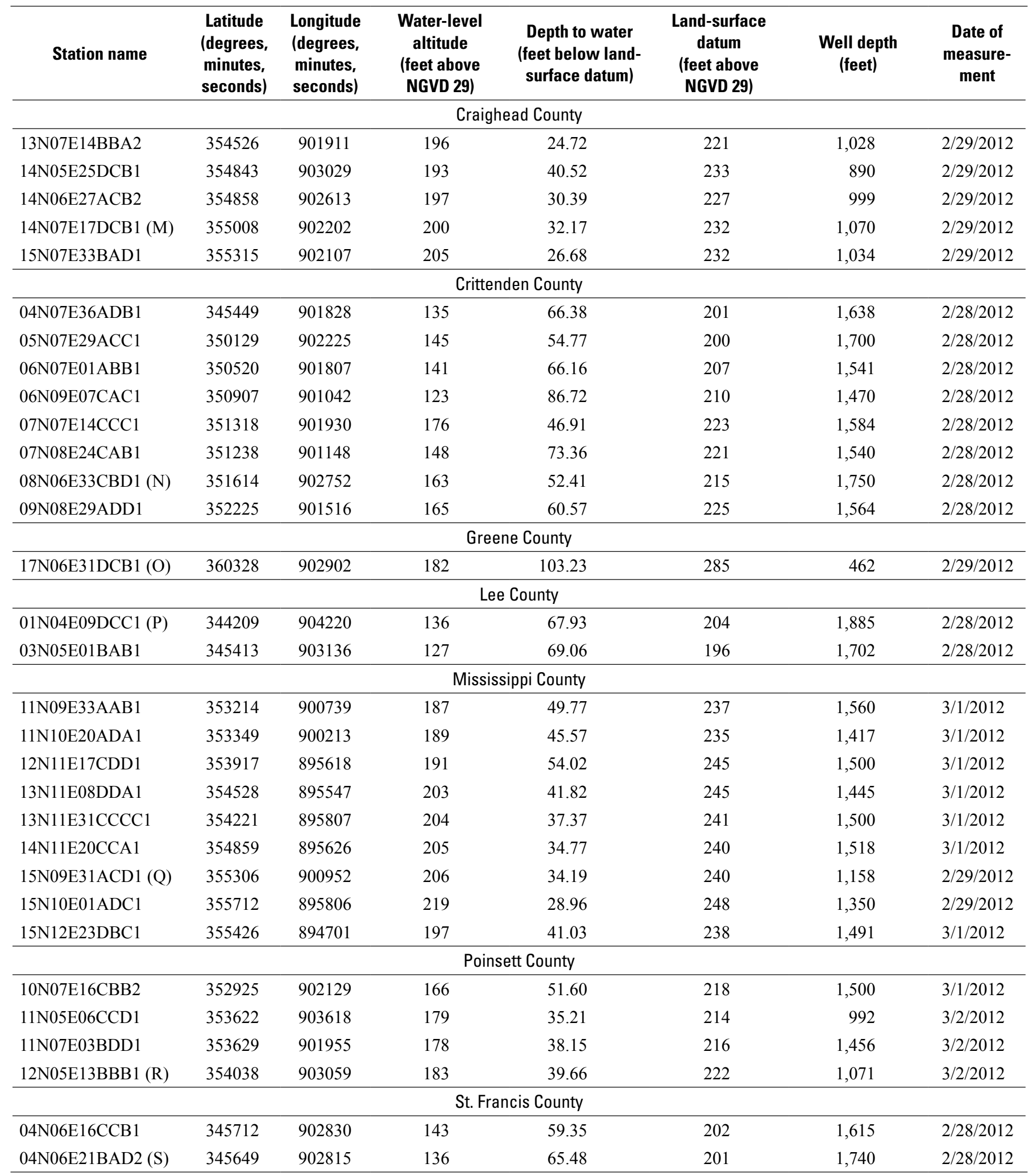


Appendix 4. Water-level data collected during February and March 2012 from wells completed in the Wilcox aquifer in southern Arkansas.

[Horizontal datum is North America Datum of 1983; NGVD 29, National Geodetic Vertical Datum of 1929; Letters in parentheses correspond to well locations in figure 10 and well hydrographs in figure 14; --, missing data]

\begin{tabular}{|c|c|c|c|c|c|c|c|}
\hline Station name & $\begin{array}{c}\text { Latitude } \\
\text { (degrees, } \\
\text { minutes, } \\
\text { seconds) }\end{array}$ & $\begin{array}{l}\text { Longitude } \\
\text { (degrees, } \\
\text { minutes, } \\
\text { seconds) }\end{array}$ & $\begin{array}{c}\text { Water-level } \\
\text { altitude } \\
\text { (feet above } \\
\text { NGVD 29) }\end{array}$ & $\begin{array}{l}\text { Depth to water } \\
\text { (feet below } \\
\text { land-surface } \\
\text { datum) }\end{array}$ & $\begin{array}{c}\text { Land-surface } \\
\text { datum } \\
\text { (feet above } \\
\text { NGVD 29) }\end{array}$ & $\begin{array}{l}\text { Well depth } \\
\text { (feet) }\end{array}$ & $\begin{array}{c}\text { Date of } \\
\text { measurement }\end{array}$ \\
\hline \multicolumn{8}{|c|}{ Clark County } \\
\hline 07S18W03BBD1 & 340917 & 925604 & 267 & 2.75 & 270 & 47 & $2 / 21 / 2012$ \\
\hline 07S18W20ABB2 & 340652 & 925757 & 232 & 9.86 & 242 & 19 & $2 / 21 / 2012$ \\
\hline 10S18W10DDB1 (T) & 335216 & 925613 & 145 & 49.99 & 195 & 215 & $2 / 21 / 2012$ \\
\hline \multicolumn{8}{|c|}{ Hempstead County } \\
\hline 13S23W04BDD1 & 333842 & 932911 & 345 & 4.51 & 350 & 14 & $2 / 21 / 2012$ \\
\hline 13S24W02DCA2 & 333829 & 933311 & 394 & 51.92 & 446 & 63 & $2 / 21 / 2012$ \\
\hline 04S16W20CBB1 (V) & 342144 & 924532 & 342 & 2.73 & 345 & 18 & $2 / 21 / 2012$ \\
\hline 05S17W10AAC1 & 341836 & 924853 & 394 & 15.57 & 410 & 26 & $2 / 21 / 2012$ \\
\hline \multicolumn{8}{|c|}{ Nevada County } \\
\hline 12S22W24CDA1 & 334046 & 931941 & 313 & 31.21 & 344 & 41 & $2 / 21 / 2012$ \\
\hline 13S21W02DCC1 & 333754 & 931426 & 251 & 63.53 & 315 & 240 & $2 / 21 / 2012$ \\
\hline 13S21W11BDA1 & 333738 & 931432 & 242 & 25.91 & 268 & - & $2 / 21 / 2012$ \\
\hline 13S21W23ABC1 & 333556 & 931423 & 319 & 42.56 & 362 & 47 & $2 / 21 / 2012$ \\
\hline 14S22W19AAA1 (X) & 333105 & 932443 & 329 & 7.92 & 337 & 75 & $2 / 21 / 2012$ \\
\hline \multicolumn{8}{|c|}{ Ouachita County } \\
\hline
\end{tabular}


Appendix 5. Difference in depth to water from 2006 to 2012 in the Wilcox aquifer in northeastern Arkansas.

[Horizontal datum is North American Datum of 1983; Vertical coordinate information is referenced to the National Geodetic Vertical Datum of 1929; positive differences in depth to water indicate a rise in water levels from 2006 to 2012 whereas negative values indicate a decline in water levels from 2006 to 2012]

\begin{tabular}{|c|c|c|c|c|c|}
\hline Station name & $\begin{array}{c}\text { Latitude } \\
\text { (degrees, minutes, } \\
\text { seconds) }\end{array}$ & $\begin{array}{l}\text { Longitude } \\
\text { (degrees, minutes, } \\
\text { seconds) }\end{array}$ & $\begin{array}{c}2006 \text { depth } \\
\text { to water } \\
\text { (feet below land- } \\
\text { surface datum) }\end{array}$ & $\begin{array}{c}2012 \text { depth } \\
\text { to water } \\
\text { (feet below land- } \\
\text { surface datum) }\end{array}$ & $\begin{array}{c}\text { Difference } \\
\text { in water level } \\
\text { from } 2006 \text { to } 2012 \\
\text { (feet) }\end{array}$ \\
\hline \multicolumn{6}{|c|}{ Craighead County } \\
\hline 13N07E14BBA2 & 354526 & 901911 & 26.89 & 24.72 & 2.2 \\
\hline 14N05E25DCB1 & 354843 & 903029 & 42.24 & 40.52 & 1.7 \\
\hline 14N06E27ACB2 & 354858 & 902613 & 30.98 & 30.39 & 0.6 \\
\hline 14N07E17DCB1 & 355008 & 902202 & 35.57 & 32.17 & 3.4 \\
\hline 15N07E33BAD1 & 355315 & 902107 & 28.00 & 26.68 & 1.3 \\
\hline \multicolumn{6}{|c|}{ Crittenden County } \\
\hline 04N07E36ADB1 & 345449 & 901828 & 59.09 & 66.38 & -7.3 \\
\hline 05N07E29ACC1 & 350129 & 902225 & 61.52 & 54.77 & 6.8 \\
\hline 06N07E01ABB1 & 350520 & 901807 & 66.06 & 66.16 & -0.1 \\
\hline 06N09E07CAC1 & 350907 & 901042 & 90.44 & 86.72 & 3.7 \\
\hline 07N07E14CCC1 & 351318 & 901930 & 68.93 & 46.91 & 22.0 \\
\hline 07N08E24CAB1 & 351238 & 901148 & 68.37 & 73.36 & -5.0 \\
\hline 08N06E33CBD1 & 351614 & 902752 & 53.96 & 52.41 & 1.6 \\
\hline 09N08E29ADD1 & 352225 & 901516 & 56.03 & 60.57 & -4.5 \\
\hline \multicolumn{6}{|c|}{ Greene County } \\
\hline 17N06E31DCB1 & 360328 & 902902 & 104.00 & 103.23 & 0.8 \\
\hline \multicolumn{6}{|c|}{ Lee County } \\
\hline 01N04E09DCC1 & 344209 & 904220 & 62.62 & 67.93 & -5.3 \\
\hline 03N05E01BAB1 & 345413 & 903136 & 51.18 & 69.06 & -17.9 \\
\hline \multicolumn{6}{|c|}{ Mississippi County } \\
\hline 11N09E33AAB1 & 353214 & 900739 & 52.29 & 49.77 & 2.5 \\
\hline 11N10E20ADA1 & 353349 & 900213 & 47.07 & 45.57 & 1.5 \\
\hline 12N11E17CDD1 & 353917 & 895618 & 52.79 & 54.02 & -1.2 \\
\hline 13N11E08DDA1 & 354528 & 895547 & 59.03 & 41.82 & 17.2 \\
\hline 13N11E31CCCC1 & 354221 & 895807 & 53.51 & 37.37 & 16.1 \\
\hline 14N11E20CCA1 & 354859 & 895626 & 37.88 & 34.77 & 3.1 \\
\hline 15N09E31ACD1 & 355306 & 900952 & 40.69 & 34.19 & 6.5 \\
\hline 15N10E01ADC1 & 355712 & 895806 & 39.93 & 28.96 & 11.0 \\
\hline 15N12E23DBC1 & 355426 & 894701 & 56.59 & 41.03 & 15.6 \\
\hline \multicolumn{6}{|c|}{ Poinsett County } \\
\hline 10N07E16CBB2 & 352925 & 902129 & 51.03 & 51.60 & -0.6 \\
\hline 11N05E06CCD1 & 353622 & 903618 & 42.72 & 35.21 & 7.5 \\
\hline 11N07E03BDD1 & 353629 & 901955 & 41.03 & 38.15 & 2.9 \\
\hline 12N05E13BBB1 & 354038 & 903059 & 47.28 & 39.66 & 7.6 \\
\hline \multicolumn{6}{|c|}{ St. Francis County } \\
\hline 04N06E16CCB1 & 345712 & 902830 & 54.36 & 59.35 & -5.0 \\
\hline 04N06E21BAD2 & 345649 & 902815 & 61.81 & 65.48 & -3.7 \\
\hline
\end{tabular}


Appendix 6. Difference in depth to water from 2006 to 2012 in the Wilcox aquifer in southern Arkansas.

[Horizontal datum is North American Datum of 1983; Vertical coordinate information is referenced to the National Geodetic Vertical Datum of 1929; positive differences in depth to water indicate a rise in water levels from 2006 to 2012, whereas negative values indicate a decline in water levels from 2006 to 2012]

\begin{tabular}{|c|c|c|c|c|c|}
\hline Station name & $\begin{array}{c}\text { Latitude } \\
\text { (degrees, minutes, } \\
\text { seconds) }\end{array}$ & $\begin{array}{c}\text { Longitude } \\
\text { (degrees, minutes, } \\
\text { seconds) }\end{array}$ & $\begin{array}{l}2006 \text { depth to water } \\
\text { (feet below land- } \\
\text { surface datum) }\end{array}$ & $\begin{array}{c}2012 \text { depth } \\
\text { to water } \\
\text { (feet below land- } \\
\text { surface datum) }\end{array}$ & $\begin{array}{c}\text { Difference in } \\
\text { water level } \\
\text { from } 2006 \text { to } 2012 \\
\text { (feet) }\end{array}$ \\
\hline \multicolumn{6}{|c|}{ Clark County } \\
\hline 07S18W03BBD1 & 340917 & 925604 & 14.72 & 2.75 & 12.0 \\
\hline 07S18W20ABB2 & 340652 & 925757 & 11.63 & 9.86 & 1.8 \\
\hline 10S18W10DDB1 & 335216 & 925613 & 48.31 & 49.99 & -1.7 \\
\hline \multicolumn{6}{|c|}{ Hempstead County } \\
\hline 13S23W04BDD1 & 333842 & 932911 & 4.91 & 4.51 & 0.4 \\
\hline 13S24W02DCA2 & 333829 & 933311 & 48.9 & 51.92 & -3.0 \\
\hline 04S16W20CBB1 & 342144 & 924532 & 4.25 & 2.73 & 1.5 \\
\hline 05S17W10AAC1 & 341836 & 924853 & 18.85 & 15.57 & 3.3 \\
\hline \multicolumn{6}{|c|}{ Nevada County } \\
\hline 12S22W24CDA1 & 334046 & 931941 & 32.01 & 31.21 & 0.8 \\
\hline 13S21W02DCC1 & 333754 & 931426 & 59.31 & 63.53 & -4.2 \\
\hline 13S21W11BDA1 & 333738 & 931432 & 26.07 & 25.91 & 0.2 \\
\hline 13S21W23ABC1 & 333556 & 931423 & 43.28 & 42.56 & 0.7 \\
\hline 14S22W19AAA1 & 333105 & 932443 & 26.03 & 7.92 & 18.1 \\
\hline \multicolumn{6}{|c|}{ Ouachita County } \\
\hline
\end{tabular}




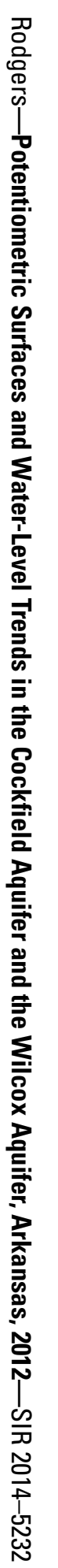

ISSN 2328-0328 (online) 